\title{
Penelitian Kapasitas Penyelesaian Konflik Pertanahan dan Proses Penyelesaian Berbasis Masyarakat
}

\author{
Trie Sakti SH CN MH
}

BAB I

PENDAHULUAN

\subsection{Latar Belakang}

Tanah merupakan kebutuhan dasar manusia, yang tidak saja memiliki nilai ekonomis tetapi juga memiliki nilai sosial, politik, budaya dan pertahanan keamanan. Terbatasnya ketersediaan tanah sungguh tidak sebanding dengan meningkatnya kebutuhan akan tanah baik untuk pembangunan maupun untuk tempat tinggal atau tempat usaha. Sehingga akses untuk memperoleh dan memanfaatkan tanah untuk memenuhi kebutuhan dasar manusia belum dapat dinikmati oleh setiap orang disebabkan antara lain karena perbedaan dalam akses modal dan akses politik.

Undang-Undang Nomor 5 tahun 1960 tentang Peraturan Dasar Pokok-Pokok Agraria (UUPA) yang diterbitkan dalam rangka mewujudkan amanat pasal 33 ayat(3) UUD 1945 sejak semula berciri populis. Namun perbandingan antara ketersediaan tanah sebagai sumber daya alam yang langka di satu sisi, dan pertambahan jumlah penduduk dengan berbagai pemenuhan kebutuhannya akan tanah di sisi lain, tidak mudah dicari titik temunya. ${ }^{1}$

Akibatnya terjadi ketimpangan pemilikan dan penguasaan tanah, di satu pihak ada individu atau kelompok yang memiliki dan menguasai tanah secara berlebihan namun di lain pihak ada yang sama sekali tidak mempunyai tanah. Ketimpangan inilah yang mengakibatkan semakin meningkatnya kesenjangan sosial di masyarakat sehingga membuat konflik pertanahan seakan-akan tidak ada habisnya.

Berkaitan dengan itu, berdasarkan data (Dit. Konflik pertanahan BPN) Tahun 2006, tercatat ada 322 kasus konflik pertanahan yang telah diidentifikasikan. Jumlah ini terus meningkat sepanjang tahunnya, Tercatat 858 kasus konflik pertanahan terjadi di tahun 2007, kemudian 520 kasus di tahun 2008, serta 194 kasus di tahun 2009.

Konflik pertanahan hampir merata terjadi di berbagai daerah, seperti di Nusa Tenggara Barat dimana rencana perluasan bandara yang akhirnya menimbulkan konflik antara pihak Angkasa Pura dalam hal ini Dirjen Perhubungan Udara dengan masyarakat setempat, begitu juga terjadi hal yang sama antara pihak Angkasa Pura Jayapura dengan masyarakat setempat dimana masyarakat mengklaim bahwa tanah sekitar bandara merupakan tanah adat masyarat setempat

1 SW Soemardjono, Maria , Tanah Dalam Perspektif Hak Ekonomi Sosial dan Budaya, 2008, Penerbit Buku Kompas, Jakarta, hlm.4. 
sehingga terjadi konflik antar mereka. Kasus tanah terlantar juga berkaitan dengan aspek sosialekonomi yang menimbulkan konflik, dimana pemegang HGU tidak mampu mengamankan haknya dan harus berhadapan dengan masyarakat sekitar lokasi HGU.

Pengertian konflik pertanahan merujuk pada Peraturan Kepala BPN RI No. 3 tahun 2011 tentang Pengelolaan Pengkajian dan Penanganan Kasus Pertanahan, adalah perselisihan pertanahan antara orang perseorangan, kelompok, golongan, organisasi, badan hukum, atau lembaga yang mempunyai kecenderungan atau sudah berdampak luas secara sosio-politis. Perbedaannya dengan sengketa pertanahan, sengketa adalah perselisihan pertanahan antara orang perseorangan, badan hukum, atau lembaga yang tidak berdampak luas secara sosio-politis. Adapun perkara pertanahan adalah perselisihan pertanahan yang penyelesaiannya dilaksanakan oleh lembaga peradilan atau putusan lembaga peradilan yang masih dimintakan penanganan perselisihannya di Badan Pertanahan Nasional Republik Indonesia.

Hasil Penelitian Puslitbang BPN tahun 2007 menunjukkan bahwa :

a. Masih banyak dijumpai semakin luas HGU yang dikuasai cenderung semakin banyak tanah yang diterlantarkan.

b. Masih banyak masalah atau sengketa dan konflik pertanahan di atas tanah HGU, antara lain disebabkan (i) adanya tanah HGU yang telah habis masa berlakunya, namun belum diajukan permohonan perpanjangan hak, karena terjadi perebutan penguasaan,(ii) adanya okupasi masyarakat disekitar tanah HGU karena tanah HGU diterlantarkan atau tidak dimanfaatkan secara optimal, (iii) adanya klaim masyarakat bahwa pemegang HGU belum membayar ganti rugi atas tanah HGU yang diklaim sebagai miliknya.

c. Kurangnya sosialisasi hukum pertanahan menyebabkan tingkat pemahaman hak dan kewajiban masyarakat dalam pengelolaan pertanahan di sekitar areal perkebunan rendah.

d. Pemanfaatan tanah HGU Perkebunan mempunyai andil yang sangat berarti dalam mendukung program pengentasan kemiskinan. Hal ini diindikasi dengan kemampuan menyerap tenaga kerja sekitar lokasi, mendukung perekonomian daerah khususnya perkebunan yang saat ini mempunyai prospek pasar antara lain komoditi kelapa sawit, karet dan kakao. Namun karena sebagian besar masyarakat tidak memiliki aset tanah yang cukup luas dan terbatasnya akses ekonomi usaha maka kehidupan masyarakat di sekitar lokasi perkebunan cenderung miskin.. ${ }^{2}$

Kondisi di atas dapat menjadi bibit timbulnya konflik di sekitar lokasi perkebunan antara masyarakat dengan pemegang HGU.

Dari data Direktorat Konflik Pertanahan menunjukkan tipologi masalah ada 8 jenis yaitu :

2 Laporan Penelitian Penataan HGU dalam rangka PPAN, 2007, Pusat penelitian dan Pengembangan Badan Pertanahan Nasional, Jakarta. 


\begin{tabular}{|c|l|r|}
\hline No. & \multicolumn{1}{|c|}{ Tipologi } & \multicolumn{1}{|c|}{ Presentase } \\
\hline 1. & Masalah Penguasaan dan Pemilikan Tanah & $\mathbf{7 8 . 2 8 \%}$ \\
\hline 2. & Masalah batas/letak bidang tanah & $\mathbf{9 . 0 9 \%}$ \\
\hline 3. & Masalah prosedur Penetapan Hak \& Pendaftaran Tanah & $\mathbf{7 . 5 8 \%}$ \\
\hline 4. & Masalah pelaksanaan putusan pengadilan & $\mathbf{3 . 2 8 \%}$ \\
\hline $\mathbf{5 .}$ & Masalah tanah ulayat & $\mathbf{0 . 5 1 \%}$ \\
\hline $\mathbf{6 .}$ & Masalah tanah obyek Landreform & $\mathbf{0 . 5 1 \%}$ \\
\hline $\mathbf{7 .}$ & Masalah ganti rugi tanah ex. Partikelir & $\mathbf{0 . 4 2 \%}$ \\
\hline $\mathbf{8 .}$ & Masalah pengadaan tanah & $\mathbf{0 . 3 4 \%}$ \\
\hline
\end{tabular}

Dari ke delapan tipologi di atas menunjukkan bahwa masalah penguasaan dan pemilikan tanah mendominasi permasalahan pertanahan lainnya.

Mencermati konflik Pertanahan yang cenderung terus meningkat setiap tahun, kiranya hal ini perlu mendapat perhatian khusus. Dari hasil penelitian Puslitbang tahun 2004, diketahui ada dua faktor penyebab terjadinya permasalahan, yaitu faktor extern yang berasal dari pertama, masyarakat, karena pemalsuan keterangan, salah lokasi, kepemilikan tidak jelas, tanda batas tidak ada, kedua, dari Lurah/Kepala Desa karena pemalsuan keterangan (keterangan waris dan keterangan kepemilikan), ketiga dari PPAT karena pemalsuan akta jual beli, keterangan waris dan keterangan kepemilikan salah, keempat dari Kantor Pajak karena penetapan wajib pajak keliru dan penetapan NJOP salah, faktor intern dari BPN sendiri karena tidak tertibnya administrasi pertanahan dan kurang cermat dalam mengidentifikasi letak, batas dan tanda bukti alas hak. ${ }^{3}$

Mengingat bahwa konflik pertanahan adalah sesuatu yang bersifat laten dan cenderung tidak dapat diidentifikasi dari awal, serta melibatkan permasalahan yang sangat kompleks, maka diperlukan sebuah kajian mengenai akar masalah dan kemungkinan penyelesaian konflik berbasis masyarakat. Penyelesaian konflik secara litigasi atau semata-mata melalui pendekatan normatif seringkali tidak mencerminkan keadilan, disamping itu juga membutuhkan waktu yang cukup lama dengan biaya tinggi. Keterlibatan masyarakat dalam penyelesaian konflik pertanahan sangat diperlukan, karena selain tanah itu sendiri, masyarakat juga merupakan subjek dan objek dari konflik tersebut, diharapkan nantinya solusi pemecahan yang diajukan dapat menjamin keadilan dalam hal penyelesaian konflik dan penggunaan tanah selanjutnya. Selain itu,

3 Laporan Penelitian Putusan Hakim Yang Berkaitan Dengan Kasus Pertanahan, 2004, Pusat penelitian dan Pengembangan Badan Pertanahan Nasional, Jakarta. 
diharapkan pula penyelesaian konflik yang cepat dan tidak berlarut-larut sehingga tidak menimbulkan kerugian lebih lanjut.

\subsection{Perumusan Masalah}

Mencermati konflik pertanahan yang terus meningkat sebaiknya penanganannya tidak hanya dilakukan dengan pendekatan hukum tetapi juga melalui pendekatan sosial budaya dengan melibatkan masyarakat yang diharapkan dapat memenuhi rasa keadilan. Oleh karena itu berdasarkan latar belakang tersebut di atas, maka dapat disusun permasalahan sebagai berikut :

1. Bagaimana bentuk dan akar permasalahan konflik pertanahan yang terjadi dalam masyarakat pada umumnya?

2. Pihak pihak mana sajakah yang seharusnya terkait dalam penanganan konflik pertanahan tersebut?

3. Bagaimana bentuk penyelesaian konflik dan proses alternatif berbasis masyarakat ?

\subsection{Tujuan}

Berdasarkan permasalahan diatas maka penelitian ini bertujuan untuk :

1. Mengetahui bentuk dan akar permasalahan dari konflik pertanahan yang terjadi dalam masyarakat

2. Mengetahui pihak pihak yang seharusnya ikut berperan serta dalam penyelesaian konflik pertanahan didalam masyarakat

3. Menemukan bentuk dan proses alternatif berbasis masyarakat dan cara penyelesaiannya secara tepat

\subsection{Kegunaan Penelitian}

Hasil penelitian ini diharapkan akan berguna baik di level pusat, provinsi, maupun Kantor Pertanahan. Kegunaan hasil penelitian ini antara lain adalah :

1. Memberikan rekomendasi kepada Pimpinan mengenai pokok-pokok pikiran/substansi dalam menyusun kebijakan penyelesaian konflik pertanahan melalui mediasi

2. Sebagai pokok pikiran untuk menyusun Naskah Akademis;

3. Naskah Akademis penyusunan Perkaban tentang Mediasi Konflik Pertanahan 


\section{BAB II \\ TINJAUAN PUSTAKA}

\subsection{Pengertian Konflik dan Partisipasi Masyarakat}

\subsubsection{Teori Mengenai Konflik}

Di dalam struktur dan formasi sosial yang bercorak agraris, maka tanah senantiasa memiliki fungsi dan peran yang bernilai tinggi baik dari sudut ekonomi, sosial, dan politik. Karena begitu besarnya peran tersebut, maka tanah menjadi obyek kepentingan dari berbagai macam aktor. Pengelolaan kepentingan tersebut senantiasa telah diatur dan ditertibkan dalan aturan per undang-undangan. Konfigurasi pertanahan yang terus berubah dan berkembang tentu saja menimbulkan banyak benturan kepentingan yang terus berjalan sehingga seharusnya membutuhkan metode penyelesaian sengketa ataupun konflik untuk mampu memberikan keadilan sosial dan kepastian hukum ${ }^{4}$.

Secara etimologi, konflik berasal dari kata kerja Latin configere yang berarti saling memukul. Secara sosiologis, Konflik adalah sebuah gejala social yang selalu terdapat di dalam setiap masyarakat atau dengan kata lain konflik merupakan bagian yang tidak terpisahkan dari kehidupan masyarakat, hal ini karena konflik merupakan salah satu produk dari hubungan sosial (social relations).Rauf (2001:2) menyatakan hubungan sosial menghasilkan dua hal yaitu: pertama, hubungan social yang mendatangkan manfaat bersama adalah hubungan sosial yang didiamkan oleh setiap masyarakat yang dinamakan hubungan sosial positif, kedua, hubungan social yang negative yang menghasilkan konflik antara mereka yang terlibat di dalamnya karena adanya pandangan bahwa satu pihak dalam hubungan social tersebut menganggap bahwa pihak lain memperoleh manfaat yang lebih besar dari hubungan sosial ini menimbulkan rasa ketidakadilan di dalam diri pihak (atau pihak-pihak) yang terlibat di dalamnya sehingga terbentuk perbedaan mengenai manfaat dari hubungan sosial tersebut. Selanjutnya menurut Galtung (2003:88-103) konflik social sebagai salah satu bentuk produk hubungan sosial dapat dibedakan dalam tiga jenis yaitu: (1) konflik kultural (kekerasan kultural); (2) konflik struktural (kekerasan struktural); dan (3) konflik kekerasan (kekerasan langsung). Dalam pandangan

\footnotetext{
${ }^{4}$ http://www.lbhaceh.org/umum/mencari-formula-penyelesaian-konflik-dan-sengketa-pertanahan-di-aceh.html
} 
Galtung, kekerasan kultural adalah kekerasan yang melegitimasi terjadinya kekerasan struktural dan kekerasan langsung serta menyebabkan tindakan kekerasan dianggap wajar saja atau dapat diterima oleh masyarakat. Kekerasan struktural adalah kekerasan yang berbentuk eksploitasi sistematis disertai mekanisme yang menghalangi terbentuknya kesadaran serta menghambat kehadiran lembaga-lembaga yang dapat menentang eksploitasi dan penindasan itu. Kekerasan jenis ini lebih tersembunyi seperti ketidakadilan, kebijakan yang menindas, dan perundanganundangan yang deskriminatif. Kekerasan struktural ini termanifestasi dalam bentuk ketimpangan kekuasaan dan ekonomi yang menyebabkan ketimpangan kesejahteraan hidup. Kekerasan langsung adalah kekerasan yang terlihat secara langsung dalam bentuk kejadian, sehingga kekerasan jenis ini sangat mudah diidentifikasi karena merupakan manifestasi dari kekerasan kultural dan struktural.

Sementara itu, Koentjaraningrat (1984:354) menyatakan bahwa konflik bisa terjadi kalau: (1) persaingan antara dua atau lebih suku bangsa dalam hal mendapat lapangan mata pencaharian hidup yang sama; (2) pemaksaan unsur-unsur kebudayaan kepada warga satu suku bangsa lain; (3) pemaksaan terhadap suku bangsa lain yang berbeda agama untuk menganut agama tertentu; (4) usaha mendominasi suku bangsa lain secara politis; (5) adanya konflik terpendam antar sukusuku bangsa yang telah bermusuhan secara adat. ${ }^{5}$

Secara umum ada 5 sumber konflik di Indonesia yaitu; pertama, sumber konflik yang diakibatkan oleh Konflik Struktural terjadi ketika ada Ketimpangan dalam akses dan kontrol terhadap sumberdaya seperti tanah, hutan dan tambang, kebijakan yang tidak adil, kesewenangwenangan dalam mengambil keputusan. Kedua, Konflik Kepentingan terjadi ketika Pemuasan kebutuhan dan cara untuk memenuhinya dari suatu kelompok, mengorbankan kelompok atau orang lain, persaingan yang tidak sehat di bidang politik, sosial dan budaya. Ketiga, Konflik Nilai disebakan oleh Perbedaan adat, nilai idiologis, implementasi nilai agama, yang tidak berkesesuaian malah saling berbenturan. Keempat, Konflik Hubungan Sosial Psikologis disebabkan oleh Stereotip, prasangka, dan stigmatisasi. Kelima, Konflik Data Terjadi ketika satu pihak Kurang informasi, adanya perbedaan pandangan, salah komunikasi, perbedaan interpretasi atas suatu masalah yang berakibat pada distorsi informasi. ${ }^{6}$

\subsubsection{Partisipasi masyarakat}

Secara etimologis partisipasi berasal dari kata inggris "participation" yang artinya pengambilan bagian. Sedangkan dalam bahasa Belanda disebut dengan "participatie" yang artinya penyertaan. Bahasa Indonesia kemudian menerjemahkan partisipasi sebagai perihal turut berperan serta dalam suatu kegiatan.

Menurut Ach. Wazir Ws., et al. (1999: 29) partisipasi bisa diartikan sebagai keterlibatan seseorang secara sadar ke dalam interaksi sosial dalam situasi tertentu. Dengan pengertian itu, seseorang bisa berpartisipasi bila ia menemukan dirinya dengan atau dalam kelompok, melalui

5 Dr. Arkanudin, M.Si, Resolusi Konflik Pertanahan Berdasarkan Pranata Adat Rektor Universitas Kapuas Sintang, Dosen FISIP dan Program Magister Ilmu Sosial UNTAN

6 http://www.titiandamai.or.id/konten.php?nama=Sumber\&op=detail sumber\&id=9 
berbagai proses berbagi dengan orang lain dalam hal nilai, tradisi, perasaan, kesetiaan, kepatuhan dan tanggungjawab bersama.

Partisipasi masyarakat menurut Isbandi (2007: 27) adalah keikutsertaan masyarakat dalam proses pengidentifikasian masalah dan potensi yang ada di masyarakat, pemilihan dan pengambilan keputusan tentang alternatif solusi untuk menangani masalah, pelaksanaan upaya mengatasi masalah, dan keterlibatan masyarakat dalam proses mengevaluasi perubahan yang terjadi.

Mikkelsen (1999: 64) membagi partisipasi menjadi 6 (enam) pengertian, yaitu:

1. Partisipasi adalah kontribusi sukarela dari masyarakat kepada proyek tanpa ikut serta dalam pengambilan keputusan;

2. Partisipasi adalah "pemekaan" (membuat peka) pihak masyarakat untuk meningkatkan kemauan menerima dan kemampuan untuk menanggapi proyek-proyek pembangunan;

3. Partisipasi adalah keterlibatan sukarela oleh masyarakat dalam perubahan yang ditentukannya sendiri;

4. Partisipasi adalah suatu proses yang aktif, yang mengandung arti bahwa orang atau kelompok yang terkait, mengambil inisiatif dan menggunakan kebebasannya untuk melakukan hal itu;

5. Partisipasi adalah pemantapan dialog antara masyarakat setempat dengan para staf yang melakukan persiapan, pelaksanaan, monitoring proyek, agar supaya memperoleh informasi mengenai konteks lokal, dan dampak-dampak sosial;

6. Partisipasi adalah keterlibatan masyarakat dalam pembangunan diri, kehidupan, dan lingkungan mereka.

Dari tiga pakar yang mengungkapkan definisi partisipasi di atas, dapat dibuat kesimpulan bahwa partisipasi adalah keterlibatan aktif dari seseorang, atau sekelompok orang (masyarakat) secara sadar untuk berkontribusi secara sukarela dalam program pembangunan dan terlibat mulai dari perencanaan, pelaksanaan, monitoring sampai pada tahap evaluasi.

\subsection{Bentuk penyelesaian Konflik}

\section{1) Secara Litigasi yaitu melalui proses di Pengadilan}

\section{a. Karakteristik}

- Prosesnya sangat formal (terikat pada hukum acara);

- Para pihak berhadap-hadapan untuk saling melawan, adu argumentasi, mengajukan alat bukti;

- Pihak ketiga netralnya (hakim) tidak ditentukan oleh para pihak, dan keahliannya bersifat umum;

- Prosesnya bersifat terbuka/transparan;

- Hasil akhir berupa putusan yang didukung pertimbangan/pandangan hakim.

\section{b. Kelebihan}


- Proses beracara jelas dan pasti.

- Putusan menentukan siapa yang benar atau salah menurut hukum.

- Putusan dapat dieksekusi atau dijalankan secara paksa.

\section{c. Kekurangan}

- Proses yang berlarut-larut atau lama untuk mendapatkan suatu putusan yang final dan mengikat;

- Menimbulkan ketegangan atau rasa permusuhan di antara para pihak;

- Kemampuan dan pengetahuan hakim yang terbatas dan bersifat umum;

- Tidak dapat dirahasiakan;

- Kurang mampu mengakomodasi kepentingan pihak asing;

- Sistem administrasi dan birokrasi peradilan yang lemah;

- Putusan hakim mungkin tidak dapat diterima oleh salah satu pihak, karena memihak salah satu pihak atau dirasa tidak adil.

\section{2) Alternatif Dispute Resolution (Alternatif Penyelesaian Sengketa)}

\section{a. Karakteristik}

- Privat, sukarela dan konsensual (didasarkan atas kesepakatan para pihak);

- Kooperatif; tidak agresif/tidak bermusuhan dan tegang

- Fleksibel dan tidak formal/tidak kaku;

- Kreatif;

- Melibatkan partisipasi aktif para pihak dan sumberdaya yang mereka miliki;

- Bertujuan untuk mempertahankan hubungan baik;

\section{b. Kelebihan ADR}

- Cepat dan murah;

- Kontrol para pihak terhadap proses dan hasil;

- Dapat menyelesaikan sengketasecara tuntas/holistik;

- Meningkatkan kualitas keputusan yang dihasilkan dan kemauan para pihak untuk menerimanya.

\section{c. Kelemahan ADR}

- Keterbatasan dukungan yuridis terhadap proses dan hasilnya, termasuk terhadap eksekusi perjanjian penyelesaian sengketa (perdamaian) yang dihasilkan.

- Proses dan keputusan yang dihasilkan tidak dapat begitu saja dipaksakan. 


\subsection{Mediasi sebagai bagian dari Proses Non Peradilan (ADR/Alternatif Penyelesaian Sengketa)}

Pengertian Alternatif Penyelesaian Sengketa adalah lembaga penyelesaian sengketa atau beda pendapat melalui prosedur yang disepakati oleh para pihak yakni penyelesaian diluar pengadilan dengan cara konsultasi, negosiasi, mediasi, konsiliasi, atau penilaian ahli (Vide Pasal 1 butir 10 UU No. 30 Tahun 1999).

Pengertian Mediasi menurut pasal 1 Ayat 6 Peraturan Mahkamah Agung No.2 Tahun 2003 adalah Penyelesaian sengketa melalui proses perundingan para pihak dengan dibantu oleh mediator.

Mediator adalah pihak yang bersifat netral dan tidak memihak yang berfungsi membantu para pihak dalam mencari berbagai kemungkinan penyelesaian sengketa (pasal 1 ayat 5 Peraturan Mahkamah Agung No.2 Tahun 2003).

Adapun pengertian mediasi menurut Takdir Rahmadi, adalah suatu proses penyelesaian sengketa antara dua pihak atau lebih melalui perundingan atau secara mufakat dengan bantuan pihak netral yang tidak memiliki kewenangan memutus. ${ }^{7}$

a) Dasar Hukum Mediasi :

- Pasal 130 HIR dan Pasal 154 RBG Hakim wajib terlebih dahulu mendamaikan para pihak yang berperkara sebelum perkaranya diperiksa

- Peraturan Mahkamah Agung Nomor 2 Tahun 2003 Tentang Prosedur Mediasi di Pengadilan

- Peraturan Presiden Nomor 10 Tahun 2006

- Peraturan Kepala Badan Pertanahan Nasional RI Nomor 3 Tahun 2011 Tentang Pengelolaan Pengkajian dan Penanganan Kasus Pertanahan

b) Ciri- ciri Mediasi :

- Proses penyelesaian sengketa melalui musyawarah/perundingan berpartisipasi secara langsung dan informal dalam menyelesaikan sengketa para pihak

- Adanya pihak ketiga yang bersifat netral dan diterima oleh para pihak yang bersengketa

- Mediator membantu para pihak untuk mencapai penyelesaian atas sengketanya

- Mediator tidak mempunyai kewenangan memutus selama proses perundingan berlangsung

- Mempunyai tujuan untuk mencapai keputusan yang dapat diterima oleh masing masing pihak yang bersengketa.

7 Prof. Dr. Takdir Rahmadi, SH LLM, Mediasi Penyelesaian Sengketa Melalui Pendekatan Mufakat, Penerbit PT RajaGrafindo Perkasa, Jakarta, 2010. 
c) Peran Mediator

(1) Peran sebelum mediasi

- Mengumpulkan informasi

- Mengundang para pihak

- Menyiapkan tempat perundingan

- Menyiapkan logistik

- Menyiapkan peralatan

(2) Peran pada saat mediasi

- Memimpin diskusi

- Memelihara atau menjaga aturan-aturan perundingan

- Mendorong para pihak untuk menyampaikan masalah dan kepentingannya secara terbuka

- mendorong para pihak agar menyadari bahwa sengketa bukan pertarungan yang harus dimenangkan tetapi diselesaikan

- Mendengar, mencatat, dan mengajukan pertanyaan

- Membantu para pihak mencapai titik temu

d) Mekanisme Pelaksanaan Mediasi Oleh BPN RI

(1) Mediasi dilaksanakan oleh pejabat/pegawai yang ditunjuk dengan surat tugas/surat perintah dari Kepala Kantor Pertanahan, Kepala Kantor Wilayah, Kepala BPN RI/Deputi Bidang Pengkajian dan Penanganan Sengketa dan Konflik Pertanahan.

(2) Mediator yang melakukan mediasi tersebut adalah termasuk Tipelogi Authoritative Mediator yaitu pejabat yang mempunyai kompetensi dibidang sengketa yang ditangani.

e) Tahapan Mediasi Oleh BPN RI

(1)Persiapan mempertemukan kedua belah pihak

- Mengetahui pokok masalah dan apakah masalah tersebut dapat diselesaikan melalui mediasi

- Pembentukan Tim Penanganan Sengketa (tentatif)

- Penyiapan bahan

- Menentukan waktu dan tempat mediasi

(2)Undangan kepada para pihak yang berkepentingan

(3) Kegiatan mediasi

- Penjelasan para mediator 
- Verifikasi para pihak, yaitu para pihak satunya memberikan data/informasi satu sama lain.

- Pengaturan pelaksanaan mediasi

- Menyatukan pemahaman dan menetapkan Agenda Musyawarah (permasalahan terfokus)

(4)Identifikasi kepentingan

(5) Generalisasi opsi para pihak

(6) Negosiasi Akhir

(7)Formalisasi Penyelesaian Sengketa

- Dirumuskan dalam bentuk kesepakatan

- Dituangkan dalam Berita Acara Mediasi

- Dibuat laporan mediasi yang berlangsung

\subsection{Para Pihak yang berkompetensi dalam penyelesaian Konflik}

Penanganan konflik adalah persoalan kebiasaan dan pilihan. Setiap pilihan resolusi konflik yang diambil seharusnya selalu mempertimbangkan kesuaian budaya dan lingkungan dimana resolusi itu dipergunakan, sehingga dapat menghindari hambatan-hambatan kultural dan struktur sosial (Salahudin, 2002:34). Lebih lanjut menurut Salahudin (2002:35) bahwa resolusi konflik sebagai bidang spesialis tersendiri berakar dan berkembang di Negara-negara Barat, tetapi bidang ini seringkali memperoleh kritik, karena penyelesaian konflik yang didasarkan pada nilai-nilai internasionalisme justru seringkali gagal memahami konflik baru sebenarnya adalah produk sampingan dampak westernisasi atau internasionalisasi liberal diberbagai belahan dunia.

Tujuan mempelajari resolusi konflik lokal adalah untuk mendorong pemahaman tentang konflik kontenporer dan menunjukkan bagaimana praktek dan pemikiran resolusi konflik berubah dalam responnya. Dalam mengupayakan resolusi konflik terhadap persengketaan yang muncul tidak hanya mereduksi satu diantara sekian banyak model penyelesaian konflik yang telah ada. Mungkin ada konflik disuatu tempat memiliki persamaan materi konflik yang sama. Tetapi sebaliknya, umumnya perbedaan geografis menyebabkan adanya perbedaan budaya. Akibatnya model resolusi konflik yang sama tidak mesti menjamin dapat menyelesaikan kasus yang sama tetapi terjadi ditempat yang berbeda.

Berdasarkan uraian tersebut, meskipun dalam penyelesaian masalah konflik sudah banyak model namun tidak semua dapat diaplikasikan secara general, hal ini menurut Francis (2006) karena resolusi konflik meskipun sudah jadikan model juga masih memiliki kelemahan. Kelemahan-kelemahan itu menurut Francis terletak pada asumsi bahwa pihak-pihak yang bertikai dapat dibujuk untuk melihat ketergantungan mereka yang sifatnya mutual, terlepas dari kekuatan relatifnya.

Menurut Colleta (1987:9), salah satu sarana yang paling efektif untuk berkomunikasi dengan massa yang tengah berkonflik adalah dengan menggunakan saluran-saluran pengaruh 
informal tradisional dan pemimpin-pemimpin setempat. Peran kepemimpinan informal tradisional ini tidak selalu diakui secara resmi oleh pemerintah, peran-peran tersebut telah berurat berakar dlam kebudayaan asli dan memperoleh legitimasinya berdasarkan factor-faktor seperti keluarga, kedudukan sebagai orang tua dan tradisi. Dengan demikian berdasarkan pendapat Colleta tersebut, menegaskan bahwa dalam mengatasi konflik termasuklah konflik dalam bidang pertanahan tidak hanya mengandalkan pendekatan yang bersifat administrative tetapi juga perlu memperhatikan saluran-saluran pengaruh pemimpin informal yang keberadaannya di tengah-tengah masyarakat sangat dihormati dan disegani.

\section{BAB III \\ METODOLOGI PENELITIAN}

\subsubsection{Metode Pendekatan}

Pertanahan di Indonesia mempunyai peran sentral bagi seluruh rakyatnya. Pertama, karena tanah digunakan untuk sebesar-besar kemakmuran rakyat. Dalam alinea keempat Pembukaan UUD 1945 bahwa ujung cita-cita negara adalah mewujudkan keadilan sosial bagi seluruh rakyat Indonesia. Negaralah yang harus berperan besar karena memiliki kekuasaan atas seluruh bumi, air, dan ruang angkasa.

Kedua, tanah sebagai identitas kebangsaan. Tanah merupakan kekayaan nasional yang diperjuangkan oleh seluruh bangsa Tndonesia. Oleh sebab itu, sejatinya menjadi hak dari bangsa Indonesia -bukan semata-mata aset pemiliknya. Bagi bangsa Indonesia, hubungan dengan tanah merupakan hak yang sangat mendasar dan asasi. Hubungan ini menentukan kesejahteraan, keadilan, sekaligus harmonisasi bangsa. Jika hubungannya centang-perenang tak tersusun baik, sudah dapat diduga yang akan muncul adalah penderitaan panjang bagi scbagian besar rakyat Indonesia. Kemiskinan serta konfllk berkepajangan akan terus berlangsung.

Ketiga, tanah harus memiliki fungsi keadilan sosial. Pemegang hak atas tanah tidak dibenarkan mempergunakan atau tldak mempergunakan tanahnya untuk kepentingan pribadi semata. Penggunaan dan pemanfaatan tanah harus sesuai dengan keadaan dan sifat haknya, sehingga memberikan manfaat sebesar-besarnya bagi pemegang hak, masyarakat, dan negara.

Keempat, tanah untuk kehidupan. Terbukanya akses rakyat kepada tanah dan kuatnya hak rakyat atas tanah memberikan kesempatan pada rakyat untuk memperbaiki sendiri kesejahteraan sosial ekonominya, hak-hak dasarnya terpenuhi, martabat sosialnya meningkat, rasa keadilannya tercukupi, dan akan tercipta harmoni sosial. ${ }^{8}$

Konflik pertanahan yang semakin hari semakin bertambah merupakan akumulasi dari ketidak adilan yang dirasakan oleh sebagian anggota masyarakat yang merasa hak-haknya selama ini telah terabaikan. Untuk mengetahui penyebab terjadinaya konflik pertanahan yang

\footnotetext{
8 Joyowinoto, Phd, Mewujudkan Keadilan dan Kesejahteraan, brighton.or.id, 2008.
} 
seakan-akan tidak ada habisnya dan tidak dapat terselesaikan maka perlu diketahui akar masalahnya dan upaya yang sudah dilakukan untuk mengatasinya. Selain upaya hukum, upaya lain seperti mediasi dengan melibatkan para pihak dan instansi terkait maupun tokoh masyarakat juga diamati.

Secara skematis konsep pemikiran penelitian kapasitas penyelesaian konflik pertanahan dan proses penyelesaian yang berbasis masyarakat, dapat dilihat sebagai berikut ;






\subsection{Lokasi Penelitian}

Untuk mendapatkan data empiris, lokasi yang dipilih sebagai tempat penelitian, yaitu

1. Provinsi Jambi;

2. Provinsi Sumatera Utara;

3. Provinsi Banten;

4. Provinsi Papua;

5. Provinsi Bali.

\subsection{Responden/Informan Penelitian}

1. Kantor Wilayah : Kepala Kantor Wilayah dan Kepala Bidang V

2. Kantor Pertanahan : Kepala Kantor Pertanahan dan Kepala Seksi V dan Kasubsi

3. Pemerintah Daerah

4. LSM

\subsection{Data Yang Digunakan dan Cara Perolehannya}

Data yang digunakan adalah data sekunder dan data primer. Data sekunder berupa: (1) daftar konflik yang terjadi di wilayah provinsi, (2) daftar pelaksanaan mediasi di wilayah provinsi dan kota/kabupaten (3) peraturan perundangan atau kebijakan yang telah dikeluarkan untuk penanganan sengketa di wilayah provinsi dan kota/kabupaten,(4) data pelaksanaan tindak lanjut penanganan oleh Kantor Wilayah BPN Provinsi dan Kantor Pertanahan Kabupaten. Data sekunder diperoleh dari Kantor Wilayah BPN Provinsi, Kantor Pertanahan Kota/Kabupaten, Pemerintah Daerah, dan LSM setempat.

Data primer dilakukan dengan cara memperoleh informasi melalui Focus Group Discussion (FGD) dan melalui kuesioner yang diisi oleh Kantor Pertanahan Kabupaten/Kota dan Kepala Kantor Wilayah BPN Provinsi.

\subsection{Analisis Data}


Penelitian ini menggunakan metode analisis deskriptif kualitatif, dengan langkah-langkah sebagai berikut:

a. Melakukan observasi ke masing-masing kantor pertanahan yang menjadi lokasi sampel;

b. Mengidentifikasi dan memetakan masalah terkait konflik yang ada dimasing-masing kantor wilayah dan kantor pertanahan dan model penyelesaiannya;

c. Mendeskripsikan semua temuan dalam kegiatan observasi (data primer dan sekunder);

d. Melakukan penajaman terhadap hasil deskripsi temuan dengan cara melalui diskusi dengan para pihak yang terkait;

e. Membuat model penyelesaian konflik berbasis masyarakat serta menggali dan mengeksplorasi kemungkinan-kemungkinan yang timbul terhadap proses penyelesaiannya dalam konteks hukum yang terkait dengan pertanahan.

\section{BAB IV}

\section{HASIL PENELITIAN}

\subsection{Gambaran Umum Daerah Penelitian}

\subsubsection{Provinsi Jambi}

Provinsi Jambi terbentuk pada tahun 1958 berdasarkan Undang-undang No. 61 tahun 1958 tanggal 25 juni 1958 yang terletak pada Pantai Timur Pulau Sumatera berhadapan dengan laut Cina Selatan dan Lautan Pasific, pada alur lalu lintas Internasional dan Regional.

Secara geografis Propinsi Jambi terletak antara $0^{\circ} 45^{1} 2^{\circ} 45^{1} \mathrm{LS}$ dan $101^{\circ} 0^{1}-104^{\circ} 55$ BT dengan wilayah keseluruhan seluas $53.435 .72 \mathrm{KM}^{2}$ dengan luas daratan $51.000 \mathrm{Km} 2$, luas lautan 425,5 Km2 dan panjang pantai $185 \mathrm{Km}$. Batas-batas Wilayah Propinsi Jambi adalah sebagai berikut :

- Sebelah Utara dengan Propinsi Riau

- Sebelah Selatan dengan Propinsi Sumatera Selatan

- Sebelah Barat dengan Propinsi Sumatera Barat

- Sebelah Timur dengan Laut Cina Selatan

Propinsi Jambi termasuk dalam kawasan segi tiga pertumbuhan Indonesia-MalaysiaSingapore (IMS-GT) dan Indonesia-Malaysia-Thailand (IMT-GT). Jarak tempuh Jambi ke Singapura jalur laut melalui Batam dengan menggunakan kapal cepat (jet-foil) ditempuh \pm 5 jam.

\section{Adminstratif Pemerintahan}

Dengan adanya pemekaran Wilayah Kabupaten seperti UU No. 25 Tahun 2008 kini Propinsi Jambi terbagi menjadi 9 Kabupaten dan 2 Kota yaitu :

1. Prov. Jambi ke Kabupaten Kerinci, (Ibukota Sungai Penuh) 419 Km.

2. Prov. Jambi ke Kabupaten Sarolangun, (Ibukota Sarolangun) $179 \mathrm{Km}$ 
3. Prov. Jambi ke Kabupaten Merangin, (Ibukota Bangko) $190 \mathrm{Km}$

4. Prov. Jambi ke Kabupaten Bungo, (Ibukota Muara Bungo) $252 \mathrm{Km}$.

5. Prov. Jambi ke Kabupaten Tebo, (Ibukota Muara Tebo) 206 Km

6. Prov. Jambi ke Kabupaten Batanghari, (Ibukota Muara Bulian) $60 \mathrm{Km}$

7. Prov. Jambi ke Kabupaten Muara Jambi, (Ibukota Sengeti) 27 Km

8. Prov. Jambi ke Kabupaten Tanjung Jabung Barat, (Ibukota Kuala Tungkal) $131 \mathrm{Km}$

9. Prov. Jambi ke Kabupaten Tanjung Jabung Timur, (Ibukota Muara Sabak) $129 \mathrm{Km}$

10. Prov. Jambi ke Kota Jambi yang juga merupakan (Ibukota Propinsi Jambi) $3 \mathrm{Km}$

11. Prov. Jambi ke Kota Sungai Penuh (Ibukota Kerinci) $420 \mathrm{Km}$

REKAPITULASI DAN DATA WLAYAH

ADMINISTRASI PEMERINTAHAN PROVINSI JAMBI

\begin{tabular}{|c|l|rrr|c|c|c|}
\hline HO & \multicolumn{1}{|c|}{ NAMA } & \multicolumn{3}{|c|}{ JUMLAH } & LUAS & JUMLAH & KET \\
\hline & KABUPATEN/KOTA & KEC & KEL & DESA & WLAYAH & PENDUDUK & \\
\hline & & \multicolumn{7}{|c}{} & & & & (KM) & (JIWA) & \\
\hline 1 & \multicolumn{1}{|c|}{3} & 4 & 6 & 7 & 8 & 9 \\
\hline 1. & KAB. KERINCI & 12 & 2 & 207 & 3.3 .55 .27 & 322.322 & \\
2. & KAB. MERANGIN & 24 & 8 & 159 & 7.679 .00 & 286.792 & \\
3. & KAB.SAROLANGUN & 10 & 6 & 125 & 6.184 .00 & 219.472 & \\
4. & KAB.BATANG HARI & 8 & 13 & 101 & 5.804 .00 & 223.061 & \\
5. & KAB.MUARO JAMBI & 8 & 4 & 129 & 5.326 .00 & 301.082 & \\
6. & KAB.TANJAB BARAT & 13 & 14 & 56 & 4.649 .85 & 247.487 & \\
7. & KAB.TANJAB TIMUR & 11 & 20 & 73 & 5.445 .00 & 211.560 & \\
8. & KAB.BUNGO & 17 & 12 & 133 & 4.659 .00 & 273.004 & \\
9. & KAB.TEBO & 12 & 5 & 90 & 6.461 .00 & 265.547 & \\
10 & KOTA JAMBI & 8 & 62 & - & 103.54 & 454.970 & \\
11 & KOTA SUNGAI PENUH & 5 & 4 & 391 & 391.5 & 77.315 & \\
& & & & & & & \\
\hline \hline & JUMLAH & 128 & 150 & 1179 & $53.475,72$ & 2.882 .612 & \\
& & & & & & \\
\hline
\end{tabular}

128 Kecamatan difinitif 1.179 Desa 150 Kelurahan

\subsubsection{Kota Jambi}

Kota Jambi dengan luas wilayah $\pm 205.38 \mathrm{~km}^{2}$ (berdasarkan UU No. 6 tahun 1986), terletak pada kordinat : $01^{\circ} 30^{\prime} 2.98^{\prime \prime}-01^{\circ} 7^{\prime} 1.07^{\prime \prime}$ Lintang Selatan dan 103 $40^{\prime} 1.67^{\prime \prime}-103^{\circ} 40$ 0.23 " Bujur Timur.

Kota Jambi adalah sebuah kota sekaligus merupakan ibu kota dari provinsi Jambi. Kota Jambi dibelah oleh sungai yang bernama Batanghari, kedua kawasan tersebut dapat dihubungi oleh jembatan yang bernama jembatan Aur Duri. Kota Jambi berada pada ketinggian rata-rata 10 sampai 60 meter di atas permukaan laut. Secara geografis posisi Kota Jambi berada pada $010^{\circ} 30^{\prime} 2,98^{\prime \prime} \mathrm{LS}$ dan $103^{\circ} 40^{\prime} 1,67^{\prime \prime}-103^{\circ} 40^{\prime} 0,22^{\prime \prime}$ BT.

\section{Batas Wilayah Administrasi}


Sebelah Utara : Kabupaten Muaro Jambi.

Sebelah Timur : Kabupaten Muaro Jambi.

Sebelah Selatan : Kabupaten Muaro Jambi.

Sebelah Barat : Kabupaten Muaro Jambi.

Dari topografinya, Kota Jambi relatif datar dengan ketinggian 0-60 m diatas permukaan laut. Bagian bergelombang terdapat di utara dan selatan kota, sedangkan daerah rawa terdapat di sekitar aliran Batanghari, yang merupakan sungai terpanjang di pulau Sumatera dengan panjang keseluruhan lebih kurang $1.700 \mathrm{~km}$ (11 km yang berada di wilayah kota Jambi dengan lebar sungai $\pm 500 \mathrm{~m}$ ), sungai ini berhulu pada Danau Diatas di Provinsi Sumatera Barat dan bermuara di pesisir timur Sumatera pada kawasan selat Berhala.

Kota Jambi beriklim tropis dengan suhu rata-rata minimum berkisar antara $22,1-23,3{ }^{\circ} \mathrm{C}$ dan suhu maksimum antara $30,8-32,6^{\circ} \mathrm{C}$, dengan kelembaban udara berkisar antara $82-87 \%$. Sementara curah hujan terjadi sepanjang tahun sebesar 2.296,1 mm/tahun (rata-rata 191,34 $\mathrm{mm} /$ bulan) dengan musim penghujan terjadi antara Oktober-Maret dengan rata-rata 20 hari hujan/bulan, sedangkan musin kemarau terjadi antara April-September dengan rata-rata 16 hari hujan/bulan.

Wilayah Kota Jambi dibagi dalam 8 kecamatan terdiri dari Kecamatan Danau Teluk dengan luas 15,70 km (7,64\%), Jambi Selatan dengan luas 34,07 km (15,59\%), Jambi Timur dengan luas 20,21 km (9,84\%), Jelutung dengan luas 7,92 km (3,86\%), Kota Baru dengan luas $77,78 \mathrm{~km}(37,87 \%)$, Pasar Jambi dengan luas 4,02 km (1,96\%), Pelayangan dengan luas 15,29 $\mathrm{km}(7,44 \%)$, dan Kecamatan Telanaipura seluas 30,39 km (14,80\%) serta 62 kelurahan dengan jumlah penduduk pada tahun 2010 mencapai 476.038 jiwa terdiri dari penduduk laki-laki 243.249 jiwa dan 232.789 jiwa perempuan. Dengan luas wilayah 205,38 $\mathrm{Km}^{2}$, dengan tingkat kepadatan penduduk mencapai 2.318 orang $/ \mathrm{km}^{2}$.

\section{Jumlah dan Tingkat Kepadatan Penduduk}

Jumlah penduduk di Kota Jambi dari tahun ke tahun terus mengalami peningkatan dari faktor kelahiran, datang, kematian dan pergi. Berdasarkan hasil Sensus Penduduk 2008, penduduk Kota Jambi berjumlah 627.245 orang yang terdiri dari 313.489 orang (49,97 persen) laki-laki dan 313.756 orang (50,02 persen) perempuan. Berdasarkan hasil Sensus Penduduk 2008 jumlah penduduk tercatat 627.245 orang. Komposisi penduduk berdasarkan jenis kelamin adalah 24,76 persen laki-laki dan 50,02 persen perempuan. Secara keseluruhan jumlah penduduk perempuan lebih tinggi dibandingkan dengan penduduk laki-laki seperti tampak dari rasio jenis kelamin penduduk yang lebih kecil dari 100. Rasio jenis kelamin adalah perbandingan antara banyaknya penduduk laki-laki dengan penduduk perempuan pada suatu daerah dan waktu tertentu. Biasanya dinyatakan dengan banyaknya penduduk laki-laki untuk 100 penduduk perempuan. Dengan luas wilayah 72,00 Km², kepadatan penduduk Kota Jambi 8,712 jiwa/km².

\subsubsection{Kabupaten Batang Hari}

Kabupaten Batang Hari terletak di bagian timur Provinsi Jambi dengan Luas Wilayah 5.180,35 Km2 dan berada diantara 1o 15' Lintang Selatan sampai dengan 2o 2' Lintang Selatan 
dan diantara 102o 30` Bujur Timur sampai dengan 104o 30` Bujur Timur, dengan batas wilayah sebagai berikut ;

- Sebelah Timur dengan kabupaten Muaro jambi

- Sebelah Utara dengan Kabupaten Muaro jambi dan Kabupaten Tebo

- Sebelah Barat dengan Kabupaten Tebo,

- Sebelah selatan berbatasan dengan Kabupaten Sorolangun, Kabupaten Muaro jambi, dan Kabupaten Musi Banyu Asin Provinsi Sumatera Selatan.

Secara topografis Kabupaten Batang Hari merupakan wilayah dataran rendah dan rawa yang dibelah Sungai Batang Hari dan sepanjang tahun tergenang air, dimana menurut elevasinya daerah ini terdiri dari 0-10 meter dari permukaan laut (11,80\%), 11-100 meter dari permukaan laut $83,70 \%$, dan 4,50 \% wilayahnya berada pada ketinggian 101-500 meter dari permukaan laut.

Kabupaten Batang Hari terletak di bagian tengah Provinsi Jambi dengan luas wilayah $5.180,35 \mathrm{Km} 2$. Kabupaten Batang Hari secara geografis terletak pada posisi $1^{\circ} 15^{\prime}$ lintang selatan sampai dengan $2^{\circ} 2^{\prime}$ lintang selatan dan diantara $102^{\circ} 30^{\prime}$ bujur timur sampai dengan $104^{\circ} 30^{\prime}$ bujur timur. Dalam lingkup provinsi letak Kabupaten Batang Hari berada di wilayah bagian tengah provinsi dan merupakan daerah perbukitan.

Kabupaten ini pada akhir tahun 2000 mempunyai jumlah penduduk 191.727 jiwa. Dilihat dari struktur umur, sekitar 60,19 persen adalah penduduk usia produktif dan sisanya 39,81\% kaum lanjut usia, dan anak-anak yang memerlukan sentuhan investasi untuk menjadikan mereka generasi yang berkualitas di masa depan. Penduduk di daerah ini terdiri dari berbagai sukiu seperti : Melayu, Jawa, Sunda, Batak, Minang, Cina, dan Suku-suku lain yang jumlahnya relatif kecil.

Berdasarkan letak geografisnya Kabupaten Batang Hari berbatasan :

1. Sebelah Utara berbatasan dengan Kabupaten Tanjung Jabung Barat.

2. Sebelah Selatan berbatasan dengan Kabupaten Sarolangun dan Provinsi Sumatera Selatan.

3. Sebelah Timur berbatasan dengan Kabupaten Muaro Jambi.

4. Sebelah Barat berbatasan dengan Kabupaten Tebo.

Wilayah administrasi Kabupaten Batang Hari terdiri dari 8 (delapan) kecamatan yang meliputi 13 (dua belas) kelurahan dan 96 (sembilan puluh satu) desa dengan berbagai perbedaan perkembangan, baik karena potensi geografis, sumber daya alam, sumber daya manusia maupun karena pembangunan prasarana pada masing-masing kecamatan dan antar kecamatan. Dilihat dari aspek geografis, kabupaten ini mempunyai letak yang strategis karena merupakan lalu lintas yang menghubungkan kawasan barat sumatera. Sesuai dengan UU No. 45 Tahun 1999, maka Kabupaten Batang Hari dimekarkan menjadi 2 (dua) kabupaten yaitu Kabupaten Batang Hari dengan Ibukota Muara Bulian dan Kabupaten Muaro Jambi dengan Ibukota Sengeti. Untuk lebih jelasnya luas wilayah Kabupaten Batang Hari per kecamatan pada Tabel. dan orientasi serta wilayah administrasi Kabupaten Batang Hari dapat di lihat pada Gambar 2.1. dan Gambar 2.2. 
Pembagian Luas Wilayah Per Kecamatan di Kabupaten Batang Hari Tahun 2004

\begin{tabular}{|l|l|l|l|}
\hline No & K e c a m a t a n & $\begin{array}{l}\text { Luas } \\
(\mathrm{Km} 2)\end{array}$ & $\begin{array}{l}\text { Prosentase } \\
\text { Luas } \\
\text { persen })\end{array}$ \\
\hline 1 & Maro Sebo Ulu & $1.143,13$ & 22,07 \\
\hline 2 & Mersam & 705,10 & 13,62 \\
\hline 3 & Batin XXIV & 801,51 & 15,47 \\
\hline 4 & Muara Tembesi & 342,42 & 6,61 \\
\hline 5 & Maro Sebo Ilir & 264,81 & 5,11 \\
\hline 6 & Muara Bulian & 484,22 & 9,35 \\
\hline 7 & Bajubang & 481,66 & 9,30 \\
\hline 8 & Pemayung & 957,50 & 18,48 \\
\hline Jumlah & $\mathbf{5 . 1 8 0 , 3 5}$ & $\mathbf{1 0 0 , 0 0}$ \\
\hline
\end{tabular}

Wilayah Kabupaten Batang Hari secara umum adalah berupa daerah perbukitan dengan ketinggian berkisar antara 11 - 500 m dari permukaan laut. Sebagian besar wilayah Kabupaten Batang Hari berada pada Daerah Aliran Sungai (DAS) Sungai Batanghari dengan rawa-rawa yang sepanjang tahun tergenang air. Secara geomorfologis wilayah Kabupaten Batang Hari merupakan daerah landai yang memiliki kemiringan berkisar antara 0 - 8 persen (92,28 persen).

Kecamatan yang terletak didaerah hulu Sungai Batanghari cenderung lebih bergelombang dibandingkan daerah hilirnya. Daerah bergelombang terdapat di Kecamatan Maro Sebo Ulu, Kecamatan Batin XXIV, Kecamatan Mersam dan Kecamatan Maro Sebo Ilir. Kecamatan Muara Tembesi, Kecamatan Muara Bulian, Kecamatan Bajubang dan Kecamatan Pemayung memiliki topografi yang cenderung lebih datar/landai sedangkan daerah dengan topografi miring dalam wilayah Kabupaten Batang Hari bisa dikatakan tidak ada.

Kabupaten Batang Hari beriklim tropis dengan temperatur udara berkisar antara 20-30 derajat celcius. Hasil pengamatan dalam 5 (lima) tahun terakhir menunjukkan bahwa jumlah curah hujan rata-rata pertahun berkisar antara 2.264,6 - 2.976,4 mm dengan kelembaban antara 62,66 - 84,55 persen serta penyinaran berkisar antara 89,3 - 133,9 persen. Curah hujan di Kabupaten Batang Hari selama tahun 2004 berjumlah 2.398,3 mm dengan banyaknya hari hujan 176 hari. Rata-rata curah hujan per bulan berkisar 199,9 mm sementara rata-rata jumlah hari hujan perbulan adalah 14 hari.

Wilayah Kabupaten Batang Hari dilalui oleh dua sungai besar yaitu Batang Tembesi dan Sungai Batanghari. Beberapa sungai lainnya yang relatif besar antara lain adalah Sungai Dangun Bangko, Sungai Kayu Aro, Sungai Rengas, Sungai Lingkar, Sungai Kejasung Besar, Sungai Jebak. Disamping sungai besar tadi terdapat pula beberapa sungai kecil yang merupakan anak-anak sungai yaitu Sungai Singoan, Sungai Bernai, Sungai Mersam, Sungai Bulian, Sungai Kandang, Sungai Aur, Sungai Bacang dan lain - lain. 
Kondisi geologi dan struktur tanah yang terdapat dalam wilayah Kabupaten Batang Hari antara lain didominasi oleh Neogin seluas 283.986 Ha diikuti endapan seluas 171.662 Ha dan Tufa Vulcan seluas 84.472 Ha. Penyebaran struktur jenis Neogin terkonsentrasi di wilayah Kecamatan Maro Sebo Ulu seluas 74.660 Ha atau 26,29 persen, sebagian wilayah Kecamatan Pemayung seluas 53.822 Ha atau 18,95 persen dan Kecamatan Mersam seluas 43.353 Ha atau 15,26 persen. Untuk jenis endapan tersebar hampir merata di tiap kecamatan sedangkan Tufa Vulcan terkonsentrasi di Kecamatan Batin XXIV seluas 32.247 Ha atau 38,17 persen dan selebihnya hampir menyebar disemua kecamatan. Keadaan struktur tanah yang ada di Kabupaten Batang Hari terdiri dari 2 (dua) jenis tanah, yaitu jenis tanah alluvial dan padsolik merah kuning. Jenis tanah alluvial berada di sekitar Sungai Batanghari dan Sungai Batang Tembesi.

\subsubsection{Kabupaten Muaro Jambi}

Kabupaten Muari Jambi terletak di antara 1o 15o 20' Lintang Selatan dan diantara 103 o 10' - 104 o 20' Bujur Timur dengan luas wilayah $5.246 \mathrm{~km} 2$, dengan batas wilayah sebagai berikut :

- Sebelah Utara dengan Kabupaten Tanjung Jabung Timur

- Sebelah Timur dengan Kabupaten Tanjung Jabung Timur

- Sebelah Barat dengan Kabupaten Batang Hari dan Kabupaten Tanjung Jabung Barat

- Sebelah selatan berbatasan dengan Provinsi Sumatera Selatan.

Wilayah administrasi Kabupaten Muaro Jambi terdiri dari 8 (delapan) kecamatan yang meliputi 5 (lima) kelurahan dan131 (seratus tiga puluh satu) desa dengan berbagai perbedaan perkembangan, baik karena potensi geografis, sumber daya alam, sumber daya manusia maupun karena pembangunan prasarana pada masing-masing kecamatan dan antar kecamatan.

\subsubsection{Provinsi Sulawesi Utara}

Propinsi Sulawesi Utara terletak di jazirah utara Pulau Sulawesi dan merupakan salah satu dari tiga propinsi di Indonesia yang terletak di sebelah utara garis khatulistiwa. Dua propinsi lainnya adalah Propinsi Sumatera Utara dan Propinsi Daerah Istimewa Aceh. Dilihat dari letak geografis Sulawesi Utara terletak pada 0.300-4.300 Lintang Utara (LU) dan 1210-1270 Bujur Timur (BT).

Sulawesi Utara merupakan salah satu dari 7 Propinsi Kepulauan yang terdiri dari 258 pulau dan 11 diantaranya berbatasan langsung dengan negara tetangga Filipina dan Laut Pasifik. Adapun secara administratif pulau yang termasuk wilayah Provinsi Sulawesi Utara dapat dilihat pada table dibawah ini:

Rekapitulasi Jumlah Pulau Di Provinsi Sulawesi Utara

\begin{tabular}{||l||c||c||c||}
\hline KABUPATEN/KOTA & JML & TERAK \\
& PULAU & BERPEGHNI & BERPENGHUNI \\
\hline
\end{tabular}




\begin{tabular}{||l||c||c||c||}
\hline Kota Manado & 3 & 3 & - \\
\hline \hline Kota Bitung & 17 & 1 & 16 \\
\hline Kab. Bolaang Mongondow & 17 & 4 & 13 \\
\hline \hline Kab. Bolmong Utara & 6 & - & 6 \\
\hline \hline Kab. Minahas Utara & 19 & 7 & 12 \\
\hline \hline Kab. Minahasa Tenggara & 24 & 3 & 21 \\
\hline \hline Kab. Minahasa Selatan & 4 & - & 9 \\
\hline \hline Kab. Kep. Talaud & 16 & 7 & 40 \\
\hline \hline Kab. Kep. Sangihe & 105 & 27 & $\mathbf{1 9 9}$ \\
\hline \hline Kab. Kep. Sitaro & $\mathbf{2 5 8}$ & 7 & $\mathbf{5 9}$ \\
\hline \hline Jumlah & & & 48 \\
\hline
\end{tabular}

\subsubsection{Kota Manado}

Kota Manado terletak di ujung jazirah utara pulau Sulawesi, pada posisi geografis $124^{\circ} 40^{\prime}-124^{\circ} 50^{\prime}$ BT dan $1^{\circ} 30^{\prime}-1^{\circ} 40^{\prime}$ LU. Iklim di kota ini adalah iklim tropis dengan suhu rata-rata $24^{\circ}-27^{\circ} \mathrm{C}$. Curah hujan rata-rata $3.187 \mathrm{~mm} /$ tahun dengan iklim terkering di sekitar bulan Agustus dan terbasah pada bulan Januari. Intensitas penyinaran matahari rata-rata 53\% dan kelembaban nisbi $\pm 84 \%$.

Luas wilayah daratan adalah 15.726 hektar. Manado juga merupakan kota pantai yang memiliki garis pantai sepanjang 18,7 kilometer. Kota ini juga dikelilingi oleh perbukitan dan barisan pegunungan. Wilayah daratannya didominasi oleh kawasan berbukit dengan sebagian dataran rendah di daerah pantai. Interval ketinggian dataran antara 0-40\% dengan puncak tertinggi di gunung Tumpa.

Wilayah perairan Kota Manado meliputi pulau Bunaken, pulau Siladen dan pulau Manado Tua. Pulau Bunaken dan Siladen memiliki topografi yang bergelombang dengan puncak setinggi 200 meter. Sedangkan pulau Manado Tua adalah pulau gunung dengan ketinggian \pm 750 meter. 
Sementara itu perairan teluk Manado memiliki kedalaman 2-5 meter di pesisir pantai sampai 2.000 meter pada garis batas pertemuan pesisir dasar lereng benua. Kedalaman ini menjadi semacam penghalang sehingga sampai saat ini intensitas kerusakan Taman Nasional Bunaken relatif rendah.

Kota Manado berbatasan dengan Kabupaten Minahasa dan Selat Mantehage di sebelah Utara, dengan Kabupaten Minahasa di sebelah Timur, dengan Kabupaten Minahasa di sebelah Selatan dan dengan Teluk Manado di sebelah Barat. Jarak dari kota Manado ke Tondano adalah $28 \mathrm{~km}$, ke Bitung $45 \mathrm{~km}$ dan ke Amurang $58 \mathrm{~km}$.

Wilayah perairan Kota Manado meliputi pulau Bunaken, pulau Siladen dan pulau Manado Tua. Pulau Bunaken dan Siladen memiliki topografi yang bergelombang dengan puncak setinggi 200 meter. Sedangkan pulau Manado Tua adalah pulau gunung dengan ketinggian \pm 750 meter.

Sementara itu perairan teluk Manado memiliki kedalaman 2-5 meter di pesisir pantai sampai 2.000 meter pada garis batas pertemuan pesisir dasar lereng benua. Kedalaman ini menjadi semacam penghalang sehingga sampai saat ini intensitas kerusakan Taman Nasional Bunaken relatif rendah.

Kota Manado berbatasan dengan Kabupaten Minahasa dan Selat Mantehage di sebelah Utara, dengan Kabupaten Minahasa di sebelah Timur, dengan Kabupaten Minahasa di sebelah Selatan dan dengan Teluk Manado di sebelah Barat. Jarak dari kota Manado ke Tondano adalah 28 km, ke Bitung $45 \mathrm{~km}$ dan ke Amurang $58 \mathrm{~km}$.

\subsubsection{Kota Bitung}

Kota Bitung merupakan salah satu pemerintah kota yang ada di Provinsi Sulawesi Utara dengan luas wilayah daratan $304 \mathrm{~km}^{2}$. Sebagian besar wilayah daratan merupakan daerah berombak, berbukit dan gunung. Secara geografis Kota Bitung terletak pada posisi diantara

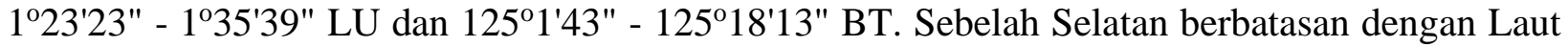
Maluku, sebelah Utara berbatasan dengan Kecamatan Likupang dan Kecamatan Dimembe (Kabupaten Minahasa Utara), Sebelah Timur berbatasan dengan Laut Maluku dan Samudera Pasifik sedangkan sebelah Barat berbatasan dengan Kecamatan Kauditan (Kabupaten Minahasa Utara). Wilayah daratan mempunyai luas $304 \mathrm{~km}^{2}$, secara administratif terbagi dalam lima wilayah kecamatan serta enam puluh kelurahan. Lima kecamatan tersebut masing-masing Kecamatan Bitung Utara (136,40 km2 ) meliputi 12 kelurahan, Kecamatan Bitung Tengah (24 km2 ) meliputi 10 kelurahan, Kecamatan Bitung Barat (33,62 km2) meliputi 10 kelurahan, Kecamatan Bitung Timur (59,08 km2) terdiri dari 13 kelurahan dan Kecamatan Bitung Selatan yang terdapat di Pulau Lembeh $(50.90 \mathrm{~km} 2)$ meliputi 15 kelurahan.

Sebagai pintu gerbang jalur laut di Provinsi Sulawesi Utara, dengan berbagai aktifitas perdagangan dan pendidikan serta dengan keberadaan sumber daya alam yang cukup memadai, Kota Bitung memiliki lahan sawah seluas $156 \mathrm{Ha}$, lahan kering $28.719 \mathrm{Ha}$ dan lainnya $1252 \mathrm{Ha}$, menunjukkan penggunaan lahan dalam pembangunan Kota Bitung cenderung maksimal. Kota Bitung merupakan kota multi dimensi dengan keragaman etnis yang dalam kesehariannya berkembang dalam nuansa kebersamaan dengan menghargai keragaman tersebut dengan didukung semangat dan budaya Mapalus. Kelurahan yang ada masih ada yang mempunyai ciri pedesaan baik dilihat dari segi fisik maupun pola hidup masyarakatnya. Masih ada beberapa 
kelurahan yang bercirikan kelurahan pesisir (Bitung Selatan, Bitung Timur dan beberapa kelurahan di Bitung Utara) maupun kelurahan yang bercirikan masyarakat petani (Bitung Utara).

Keberhasilan pembangunan Kota Bitung yang dicerminkan dari laju pertumbuhan ekonomi cukup menggembirakan, telah menjadi daya tarik tersendiri bagi para migran untuk tinggal dan bekerja di Kota Bitung. Rata-rata kepadatan penduduk pada Tahun 2005 mencapai sekitar 558 jiwa per $\mathrm{km}^{2}$. Menyadari heterogenitas penduduk dengan berbagai latar belakang budaya maka pembangunan Kota Bitung diarahkan pada terwujudnya Kota Bitung sebagai kota pelabuhan internasional, industri, pariwisata, perdagangan dan jasa yang berwawasan lingkungan dan unggul di era globalisasi sesuai dengan visi yang akan dicapai oleh pemerintah dan masyarakat Kota Bitung. Berbagai tantangan, potensi dan dinamika lingkungan strategis yang mempengaruhi perkembangan pembangunan Kota Bitung merupakan motivasi bagi pemerintah dan masyarakat serta semua stake holders pembangunan untuk merancang dan melaksanakan pembangunan dengan mengarahkan pada skala prioritas yang dapat menggerakkan roda perekonomian rakyat dan menjamin kelangsungan pembangunan yang berkelanjutan (sustainable development).

\section{Tanjung dan Teluk}

Di sepanjang pantai Sulawesi Utara baik di pantai dataran utama maupun di pantai pulaupulau, terdapat banyak tanah yang menjorok ke tengah laut (tanjung) dan perairan laut yang menjorok ke daratan (teluk). Beberapa tanjung yang cukup ternama adalah Tanjung Atep, Tanjung Pulisan, Tanjung Salimburung, Tanjung Kelapa (di wilayah Kabupaten Minahasa); Tanjung Binta, Tanjung Dulang, Tanjung Flesko, dan Tanjung Tanango (di wilayah Kabupaten Bolaang Mongondow). Sementara di Kabupaten Sangihe Talaud antara lain; Tanjung Binta, Tanjung Barurita, Tanjung Bulude, Tanjung Bunangkem, Tanjung Buwu dan Tanjung Esang. Teluk-Teluk yang cukup dikenal di wilayah ini antara lain; Teluk Amurang, Teluk Belang, Teluk Manado, Teluk Kema (Minahasa dan Manado); Teluk Tombolata, Teluk Taludaa dan Teluk Bolaang (Bolaang Mongondow), Teluk Manganitu, Teluk Peta, Teluk Miulu, Teluk Dago dan Teluk Ngalipeang (Sangihe Talaud) sebagai tempat perdagangan dan wisata.

\subsubsection{Kabupaten Minahasa Utara}

Letak geografis Kabupaten Minahasa Utara antara $124^{\circ} 40^{\prime} 38,39^{\prime \prime}$ hingga $125^{\circ} 15^{\prime}$ 15,53' ' BT dan antara $1^{\circ} 17^{\prime} 51,93^{\prime}$ ' hingga $1^{\circ} 56^{\prime} 31,03^{\prime \prime}$ LU dengan batas-batas: sebelah utara wilayah Kabupaten Sangihe dan Laut Sulawesi, sebelah Timur Kota Bitung dan Laut Maluku, sebelah selatan Kabupaten Minahasa.

Kabupaten Minahasa Utara beribukotakan Airmadidi. Memiliki luas wilayah 955,32 km2 dan terbagi menjadi 8 kecamatan. Wilayahnya berbatasan dengan Kabupaten Kepulauan Sangihe dan Talaud dan Laut Sulawesi di sebelah utara, Kabupaten Minahasa di sebelah selatan, Kota Manado di sebelah barat, dan Kota Bitung dan Laut Maluku di sebelah timur. Topografi wilayahnya sebagian besar berupadataran rendah, dan sebagian kecil berbukit-bukit dan bergunung memungkinkan dikembangkannya wisata alam, budaya dan bahari. Kegiatan menyelam, snorkeling, renang, sport fishing, dan rekreasi luar ruangan. 


\subsubsection{Provinsi Banten}

Wilayah Banten terletak di antara 5 $5^{\prime} 50^{\prime \prime}-7^{\circ} 1^{\prime} 11^{\prime \prime}$ Lintang Selatan dan 105¹'11"106 ${ }^{\circ}$ '12" Bujur Timur, berdasarkan Undang-Undang Republik Indonesia Nomor 23 tahun 2000 luas wilayah Banten adalah 9.160,70 km². Provinsi Banten terdiri dari 4 kota, 4 kabupaten, 154 kecamatan, 262 kelurahan dan 1.273 desa.

Wilayah laut Banten merupakan salah satu jalur laut potensial, Selat Sunda merupakan salah satu jalur lalu lintas laut yang strategis karena dapat dilalui kapal besar yang menghubungkan Australia dan Selandia Baru dengan kawasan Asia Tenggara misalnya Thailand, Malaysia, dan Singapura. Di samping itu Banten merupakan jalur penghubung antara Jawa dan Sumatera. Bila dikaitkan posisi geografis dan pemerintahan maka wilayah Banten terutama daerah Tangerang raya (Kota Tangerang, Kabupaten Tangerang, dan Kota Tangerang selatan) merupakan wilayah penyangga bagi Jakarta. Secara ekonomi wilayah Banten memiliki banyak industri. Wilayah Provinsi Banten juga memiliki beberapa pelabuhan laut yang dikembangkan sebagai antisipasi untuk menampung kelebihan kapasitas dari pelabuhan laut di Jakarta dan ditujukan untuk menjadi pelabuhan alternatif selain Singapura.

Batas-batas Wilayah Propinsi Banten adalah sebagai berikut :

- Sebelah Utara dengan Laut Jawa

- Sebelah Selatan dengan Samudera Indonesia

- Sebelah Barat dengan Selat Sunda

- Sebelah Timur dengan Daerah Khusus Ibukota Jakarta dan Jawa Barat.

\subsubsection{Kabupaten Pandeglang}

Wilayah Kabupaten Pandeglang secara geografis terletak antara $6^{\circ} 21^{\prime}-7^{\circ} 10^{\prime}$ Lintang Selatan dan $104^{\circ} 48^{\prime}-106^{\circ} 11^{\prime}$ Bujur Timur dengan luas daerah $2.747 \mathrm{~km}^{2}$ atau sebesar 29,98 persen dari luas Provinsi Banten. Kota Pandeglang sebagai Ibukota Kabupaten berjarak $23 \mathrm{~km}$ dari Ibukota Provinsi Banten (Serang) dan $111 \mathrm{~km}$ dari Ibukota Negara Indonesia, Jakarta. Bentuk topografi wilayah Kabupaten Pandeglang di daerah Tengah dan Selatan pada umumnya merupakan dataran dengan ketinggian gunung-gunungnya yang relatif rendah yaitu Gunung Payung (480 m), Gunung Honje (623 m), Gunung Tilu (582) dan Gunung Raksa (320 m). Luas wilayah ini sekitar 85,07 persen dari luas kabupaten.

Sementara daerah Utara sekitar 14,93 \% dari luas kabupaten merupakan dataran tinggi karena memiliki gunung-gunung seperti Gunung Karang (1.778 m), Gunung Pulosari (1.346 m) dan Gunung Aseupan $(1.174 \mathrm{~m})$. Dari segi geomorfologi, wilayah Kabupaten Pandeglang termasuk ke dalam Zona Bogor yang merupakan jalur perbukitan.

\section{Batas Wilayah Administrasi}

Sebelah Utara : Kabupaten Serang.

Sebelah Timur : Kabupaten Lebak.

Sebelah Selatan : Samudra Indonesia.

Sebelah Barat : Selat Sunda. 
Sejak bulan Juli 2007 Kabupaten Pandeglang dibagi menjadi 35 kecamatan dan 335 desa/kelurahan dengan 2 (dua) tambahan kecamatan, yaitu kecamatan Majasari dan kecamatan Sobang. Status hukum desa dan kelurahan di Kabupaten Pandeglang telah berstatus desa dan kelurahan definitif. Dari 335 desa/kelurahan yang ada, 322 merupakan desa sedangkan 13 sisanya merupakan kelurahan. Berdasarkan data Podes Sensus Ekonomi 2007, 311 desa/kelurahan berstatus pedesaan dan hanya 24 yang berstatus perkotaan. Hal ini disebabkan oleh keberadaan sarana dan prasarana, seperti keadaan jalan serta fasilitas sosial dan umum yang belum menyebar secara merata di setiap desanya.

Dari 13 Kelurahan di Kabupaten Pandeglang, Kelurahan Kabayan adalah salah satu kelurahan terdekat dan menjadi Kelurahan Penyangga dari Pusat Pemerintahan Kabupaten Pandeglang, Kelurahan Kabayan merupakan gerbang masuk menuju Pandeglang melalui arah sebelah timur, yaitu dari Bogor dan Kabupaten Lebak.

\subsubsection{Kabupaten Lebak}

Secara geografis wilayah Kabupaten Lebak berada pada $105^{\circ} 25^{\prime}-106^{\circ} 30^{\prime}$ BT dan $6^{\circ} 18^{\prime}$ $7^{\circ} 00^{\prime}$ LS. Bagian utara kabupaten ini berupa dataran rendah, sedang di bagian selatan merupakan pegunungan, dengan puncaknya Gunung Halimun di ujung tenggara, yakni di perbatasan dengan Kabupaten Bogor dan Kabupaten Sukabumi. Sungai Ciujung mengalir ke arah utara, merupakan sungai terpanjang di Banten. Kabupaten Lebak secara topografi memiliki 3 (tiga) karakteristik ketinggian dari permukaan laut, yaitu:

1. 0 - 200 Meter, untuk wilayah sepanjang Pantai Selatan.

2. 201 - 500 Meter, untuk wilayah Lebak Tengah.

3. 501 - 1000 Meter, untuk wilayah Lebak Timur dengan puncaknya yaitu Gn. Sanggabuana dan Gn. Halimun.

Ketinggian dari permukaan laut setiap Ibu Kota Kecamatan di Kabupaten Lebak sangat beragam, yang tertinggi adalah Kecamatan Muncang dan Sobang (260 meter), yang terendah Kecamatan Bayah dan Cihara (3 meter).

\section{Batas Wilayah Administrasi}

Sebelah Utara $\quad$ : Kabupaten Serang dan Tangerang.

Sebelah Timur $\quad$ : Kabupaten Bogor dan Kabupaten Sukabumi.

Sebelah Selatan : : Samudera Indonesia.

Sebelah Barat $\quad$ : Kabupaten Pandeglang.

Kabupaten Lebak memiliki luas wilayah $304.472 \mathrm{Ha}\left(3.044,72 \mathrm{Km}^{2}\right)$ yang terdiri dari 28

Kecamatan dengan 340 desa dan 5 kelurahan. Kecamatan paling luas wilayahnya adalah Kecamatan Cibeber dan yang paling kecil luas wilayahnya adalah Kecamatan Kalanganyar. Pusat pemerintahan di Kecamatan Rangkasbitung, yang berada di bagian utara wilayah kabupaten. Kota ini dilintasi jalur kereta api Jakarta-Merak. Baduy merupakan salah satu objek 
wisata yang dimiliki Kabupaten Lebak dan sering dikunjungi wisatawan mancanegara karena memiliki keunikan tersendiri.

Sedangkan dari kondisi jarak dari Ibu Kota Kecamatan ke Kota Rangkasbitung sebagai Ibu Kota Kabupaten Lebak, Kecamatan paling jauh adalah Kecamatan Cilograng sejauh 160 KM, Kecamatan paling dekat adalah Kecamatan Rangkasbitung dengan jarak 1 KM.

Seiring dengan semakin meningkatnya jumlah penduduk dan volume kegiatan pemerintahan, pembangunan dan pemberdayaan masyarakat desa, maka dikeluarkan Peraturan Daerah Kabupaten Lebak Nomor 1 Tahun 2008 mengenai pemekaran 25 desa di Kabupaten Lebak yang pada akhirnya jumlah desa/kelurahan berjumlah 340 desa dan 5 Kelurahan.

\subsubsection{Kabupaten Tangerang}

Kabupaten Tangerang terletak di bagian Timur Propinsi Banten pada koordinat $6^{\circ} 00^{\prime}-$ $6^{\circ} 20^{\prime} \mathrm{LS}$ dan $106^{\circ} 20^{\prime}-106^{\circ} 43^{\prime} \mathrm{BT}$. Luas wilayah Kabupaten Tangerang 1.110,38 $\mathrm{Km}^{2}$ atau 12,62 $\%$ dari seluruh luas wilayah Propinsi Banten.

Secara Topografi, Kabupaten Tangerang berada pada wilayah dataran yang terdiri dari wilayah dataran rendah dan dataran tinggi. Dataran rendah sebagian besar berada di wilayah Utara yaitu Kecamatan Teluknaga, Mauk, Kemiri, Sukadiri, Kresek, Kronjo, Pakuhaji, dan Sepatan. Sedangkan dataran tinggi berada di wilayah Bagian Tengah ke arah Selatan. Ketinggian wilayah berkisar antara $0-85 \mathrm{~m}$ di atas permukaan laut. Cuaca hujan setahun rata-rata $1,745 \mathrm{~mm}$ dan temperatur udara berkisar antara $23^{\circ} \mathrm{C}-33^{\circ} \mathrm{C}$. Iklim ini dipengaruhi oleh wilayah di bagian uatara yang merupakan daerah pesisir pantai dengan panjang $\pm 50 \mathrm{~km}$.

\section{Batas Wilayah Administrasi}

Sebelah Utara $\quad$ : Laut Jawa.

Sebelah Timur : : Provinsi DKI Jakarta dan Kota Tangerang.

Sebelah Selatan $\quad$ : Kabupaten Bogor dan Kota Depok.

Sebelah Barat $\quad$ : Kabupaten Serang dan Lebak.

Jarak antara Tangerang dengan pusat pemerintahan Republik Indonesia sekitar $30 \mathrm{~km}$. Keduanya dihubungkan dengan jalur lalu lintas darat bebas hambatan Jakarta-Merak yang menjadi alur utama lalu lintas perekonomian antara Pulau Jawa dengan Pulau Sumatera. Semula luas daerah Kabupaten Tangerang adalah 128.281 ha atau $1.283 \mathrm{Km}^{2}$. Luas daerah tersebut mengalami pengurangan dengan terbentuknya Kotamadya Tangerang pada tahun 1993 (UU No.2 tahun 1993) yang secara administratif pemerintahan berdiri sendiri dan statusnya setingkat dengan Kabupaten Tangerang serta mengalami pengurangan luas wilayah kembali dengan terbentuknya Kota Tangerang Selatan pada tahun 2008 (UU RI No. 51 tahun 2008) sehingga luas wilayah Kabupaten Tangerang saat ini adalah 1.013,22 $\mathrm{Km}^{2}$.

Lahan di wilayah Kabupaten Tangerang difungsikan antara lain sebagai lahan pertanian (sawah, kebun, perkebunan dan peternakan, perikanan (tambak), hutan, permukiman, industri, perdagangan, padang golf, perairan dan lain-lain). Saat ini fungsi tersebut mengalami perubahan 
dengan kecenderungan lahan pertanian makin menyusut, sebaliknya lahan non pertanian (permukiman, industri, perdagangan) makin bertambah.

Secara administratif, Kabupaten Tangerang terdiri dari 29 Kecamatan, Kelurahan dan desa. Wilayah Kabupaten Tangerang juga dibagi ke dalam tiga wilayah pusat pertumbuhan yaitu Balarja, Tigaraksa serta Teluknaga.

Kecamatan di Kabupaten Tangerang

\begin{tabular}{|c|c|c|c|}
\hline No & Kecamatan & $\begin{array}{c}\text { Luas Daerah } \\
(\mathrm{Km} 2)\end{array}$ & Keterangan \\
\hline 1. & Tigaraksa & 48.74 & \\
\hline 2. & Cisoka & 55.99 & \\
\hline 3. & Solear & & Pemekaran dari Kec. Cisoka \\
\hline 4. & Jambe & 26.02 & \\
\hline 5. & Cikupa & 42.68 & \\
\hline 6. & Panongan & 34.93 & \\
\hline 7. & Curug & 40.97 & \\
\hline 8. & Kelapa Dua & & Pemekaran dari Kec. Curug \\
\hline 9. & Legok & 41.06 & \\
\hline 10. & Pagedangan & 50.57 & \\
\hline 11. & Cisauk & 43.38 & \\
\hline 12. & Pasar Kemis & 60.53 & \\
\hline 13. & Sindang Jaya & & Pemekaran dari Kec. Pasar Kemis \\
\hline 14. & Rajeg & & \\
\hline 15. & Mekarbaru & & Pemekaran dari Kec. Kronjo \\
\hline 16. & Balaraja & 57.48 & \\
\hline 17. & Sukamulya & & Pemekaran dari Kec. Balaraja \\
\hline 18. & Jayanti & 26.91 & \\
\hline 19. & Kresek & 55.60 & \\
\hline 20. & Gunungkaler & & Pemekaran dari Kec. Kresek \\
\hline 21. & Kronjo & 68.05 & \\
\hline 22. & Mauk & 51.42 & \\
\hline 23. & Kemiri & 32.70 & \\
\hline 24. & Sukadiri & 24.14 & \\
\hline 25. & Sepatan & 56.24 & \\
\hline 26. & Sepatan Timur & 35.59 & Pemekaran dari Kec. Sepatan \\
\hline 27. & Pakuhaji & 51.87 & \\
\hline 28. & Teluknaga & 40.58 & \\
\hline 29. & Kosambi & 29.76 & \\
\hline
\end{tabular}

\subsubsection{Provinsi Papua}

Papua adalah sebuah provinsi di Indonesia yang terletak di pulau Nugini bagian barat atau west New Guinea. Papua juga sering disebut sebagai Papua Barat karena Papua bisa merujuk kepada seluruh pulau Nugini termasuk belahan timur negara tetangga, east New Guinea atau Papua Nugini. Papua Barat adalah sebutan yang lebih disukai para nasionalis yang ingin memisahkan diri dari Indonesia dan membentuk negara sendiri. Provinsi ini dulu dikenal dengan 
panggilan Irian Barat sejak tahun 1969 hingga 1973, namanya kemudian diganti menjadi Irian Jaya oleh Soeharto pada saat meresmikan tambang tembaga dan emas Freeport, nama yang tetap digunakan secara resmi hingga tahun 2002.

Nama provinsi ini diganti menjadi 'Papua' sesuai UU No 21/2001 Otonomi Khusus Papua. Pada masa era kolonial Belanda, daerah ini disebut Nugini Belanda (Dutch New Guinea). Asal kata Irian adalah Ikut Republik Indonesia Anti-Netherland. Kata Papua sendiri berasal dari bahasa melayu yang berarti rambut keriting, sebuah gambaran yang mengacu pada penampilan fisik suku-suku asli.

Pada tahun 2004, disertai oleh berbagai protes, Papua dibagi menjadi dua provinsi oleh pemerintah Indonesia; bagian timur tetap memakai nama 'Papua' sedangkan bagian baratnya menjadi Irian Jaya Barat.

Luas wilayah Luas $420.540 \mathrm{~km}$

\subsubsection{Kota Jayapura}

Posisi / Letak Kota Madya Daerah Tingkat II Jayapura berdiri sejak tanggal 21 September 1993 berdasarkan Undang - undang No. 6 Tahun 1993 terletak dibagian Utara

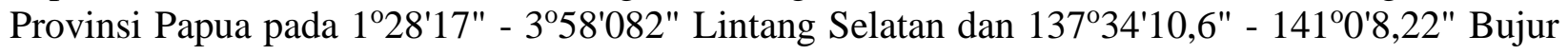
Timur.

Luas Kota Jayapura adalah $940 \mathrm{Km}^{2}$ atau $94.000 \mathrm{Ha}$, Terdiri dari 4 Distrik, terbagi habis menjadi 20 Kelurahan dan 11 Kampung. Wilayah Kota Mempunyai Batas Administratif :

- Utara : lautan Pasifik

- Selatan : Distrik Arso Kabupaten Keerom

- $\quad$ Timur : Negara PNG

- Barat : Distrik Sentani dan Depapre Kabupaten Jayapura

Kotamadya Jayapura dengan luas wilayah 94.000 Ha terdapat $\pm 30 \%$ tidak layak huni, karena terdiri dari perbukitan yang terjal, rawa-rawa dan hutan dilindung dengan kemiringan $40 \%$ bersifat konservasi dan hutan lindung.

Kota ini didominasi oleh kawasan terbuka berupa hutan sekunder sampai primer. Kawasan terbuka meliputi fungsi lindung dan fungsi budidaya.

\begin{tabular}{|l|l|l|l|}
\hline \multicolumn{5}{|l|}{ Luas Pemanfaatan Lahan di Kota Jayapura Tahun 2004 } \\
\hline Kawasan & Penggunaan Lahan & Luas Area (Ha) & Pemanfaatan (\%) \\
\hline Budidaya & Pemukiman & $8.537,82$ & 9,08 \\
\hline & Wilayah Produksi & $3.082,00$ & 3,28 \\
\hline & Alang-alang & $1.875,00$ & 1,99 \\
\hline & Rawa / Pasang Surut & 75,00 & 0,09 \\
\hline & Danau & 650,00 & 0,69 \\
\hline Jumlah & Hutan yang belum difungsikan & $\mathbf{1 4 . 2 1 9 , 8 2}$ & $\mathbf{1 5 , 1 3}$ \\
\hline Hutan Lindung & Hutan Lindung Peg. Djar & $2.246,00$ & 73,29 \\
\hline & & & 2,39 \\
\hline
\end{tabular}




\begin{tabular}{|c|c|c|c|}
\hline & Hutan Lindung Abepura & 561,20 & 0,60 \\
\hline & Cagar Alam Peg. Cycloop & $6.431,78$ & 6,84 \\
\hline & Taman Wisata Teluk Youtefa & $1.650,00$ & 1,76 \\
\hline \multicolumn{2}{|l|}{ Jumlah } & $79.780,18$ & 84,87 \\
\hline \multicolumn{2}{|c|}{\begin{tabular}{|l|l|} 
J U M L A H TO T A L \\
\end{tabular}} & $94.000,00$ & 100,00 \\
\hline
\end{tabular}

\subsubsection{Kabupaten Jayapura}

Kabupaten Jayapura secara yuridis sudah dimekarkan sesuai Undang-Undang Nomor 26 Tahun 2003 menjadi 3 (tiga) Kabupaten yaitu Kabupaten Jayapura, Kabupaten Keerom dan Kabuapten Sarmi. Ditinjau dari astronomi Kabupaten Jayapura terletak pada $129^{\circ} 00^{\prime} 16^{\prime \prime}$ BB $141^{\circ} 01^{\prime} 47^{\prime \prime}$ BT dan 2023'10" LU - 9 $15^{\prime} 00^{\prime \prime}$ LS, dengan batas-batas wilayah administrasi sebagai berikut :

- Sebelah Utara berbatasan dengan Samudra Pasifik dan Kabupaten Sarmi.

- Sebelah Selatan berbatasan dengan Kabupaten Pegunungan Bintang.

- Sebelah barat berbatasan dengan Kabupaten Sarmi.

- Sebelah Timur berbatasan dengan Kota Jayapura dan Kabupaten Keerom.

- Luas wilayah Kabupaten Jayapura saat ini adalah $\pm 16.385 .405 \mathrm{~km}^{2}$.

Keadaan topografi dan lereng umumnya relatif terjal dengan kemiringan $5 \%-30 \%$ serta mempunyai ketinggian aktual $0,5 \mathrm{~m}$ dpl - $1500 \mathrm{~m}$ dpl. Daerah pesisir pantai utara umumnya berupa dataran rendah yang bergelombang dengan kemiringan $0 \%-10 \%$ yang ditutupi dengan endapan alluvial. secara fisik, selain dataran juga terdiri dari rawa ( $\pm 13,700 \mathrm{Ha})$. sebagian besar wilayah Kabupaten Jayapura $(72.09 \%$ ) berada pada kemiringan diatas $41 \%$, sedangkan kemiringan $0-15 \%$ berkisar $23,74 \%$.

\section{Ketinggian (Fisiografi)}

Ketinggian tempat sebagian besar dibawah $500 \mathrm{~m}$ dpl ( \pm 606.400 ha atau 61,01 \% ) ketinggian 500-1000 m dpl dan ketinggian $1000-2000 \mathrm{~m}$ dpl ( \pm 149.900 ha atau $15.08 \%$ ). Pegunungan di wilayah Kabupaten Jayapura antara lain pegunungan Cycloop yang terbentang antar Distrik Sentani, Sentani Barat, Sentani Timur dan Depapre disebelah Utara, selain itu disebelah Selatan terdapat pegunungan Kramor di Distrik Kaureh.

\subsubsection{Provinsi Bali}

\subsubsection{Kabupaten Badung}

Secara geografis Kabupaten Badung berada pada 08 14'17"-08 50'57" LS dan $115^{\circ} 05^{\prime} 02^{\prime \prime}-$ $115^{\circ} 15^{\prime} 09^{\prime \prime}$ BT, membentang di tengah Pulau Bali dengan luas wilayah 418,52 $\mathrm{km}^{2}$ ( 7,43\% luas Pulau Bali ), bagian utara daerah ini merupakan daerah pegunungan yang berudara sejuk, berbatasan dengan Kabupaten Buleleng, sedangkan di bagian selatan merupakan dataran rendah dengan pantai berpasir putih dan berbatasan langsung dengan Samudra Indonesia. Bagian tengah merupakan daerah persawahan dengan pemandangan yang asri dan indah, berbatasan dengan Kabupaten Gianyar dan Kota Denpasar disebelah Timur, sedangkan di sebelah Barat berbatasan dengan kabupaten Tabanan. Secara topografi, Kabupaten Badung merupakan daerah berikilim 
tropis yang memiliki dua musim yaitu musim kemarau (April - Oktober) dan musim hujan (Nopember - Maret), dengan curah hujan rata-rata pertahun antara 893,4 - 2.702,6 mm. Suhu rata-rata $25^{\circ}-30^{\circ} \mathrm{C}$ dengan Kelembaban udara rata-rata mencapai $79 \%$.

\section{Batas Wilayah Administrasi}

Sebelah Utara : Kabupaten Buleleng.

Sebelah Timur : Kabupaten Gianyar dan Kota Denpasar.

Sebelah Selatan : Samudera Indonesia.

Sebelah Barat : Kabupaten Tabanan.

Secara administratif Kabupaten Badung terbagi menjadi 6 wilayah kecamatan yang terbentang dari bagian Utara ke Selatan yaitu Kecamatan Petang, Abiansemal, Mengwi, Kuta, Kuta Utara, \& Kuta Selatan. Disamping itu di wilayah ini juga terdapat 16 Kelurahan, 46 Desa, 369 Banjar Dinas, 164 Lingkungan 8 Banjar Dinas Persiapan dan 8 Lingkungan Persiapan. Dari 6 kecamatan ini, Kecamatan Petang memiliki luas wilayah terbesar yakni $115 \mathrm{Km}^{2}$, sedangkan Kecamatan Kuta merupakan kecamatan yang terkecil dengan luas wilayah $17,52 \mathrm{Km}^{2}$.

Di Kabupaten Badung terdapat 26 daerah yang dapat disebut daerah urban, sedang 36 lainnya masih bersifat rural. Sementara itu yang menarik adalah selain lembaga Pemerintahan Kabupaten Badung juga memiliki Lembaga Adat yang terdiri dari 119 Desa Adat, 523 Banjar dan 523 Sekaa Teruna. Disamping itu, terdapat pula 1 BPLA Kabupaten dan 6 BPLA Kecamatan serta 1 Widyasabha Kabupaten dan 6 Widyasabha Kecamatan. Sebaga lembaga tradisional, lembaga adat tersebut memiliki peran penting dalam pembangunan di Kabupaten Badung pada khususnya, dan Bali pada umumnya.

Sebagaimana lazimnya sebuah lembaga adat, anggota masyarakat adat ini terikat dalam suatu aturan adat yang disebut awig-awig. Keberadaan awig-awig ini sangat mengikat warganya sehingga umumnya masyarakat sangat patuh kepada adat. Sebab, keberadaan lembaga adat ini telah menjadi sarana yang sangat ampuh dalam menjaring partisipasi masyarakat. Banyak keberhasilan program yang dicanangkan pemerintah di daerah ini terjadi karena adanya keterlibatan dan peran serta lembaga adat yang ada.

\section{Jumlah dan Tingkat Kepadatan Kependudukan}

Jumlah penduduk di Kabupaten Badung dari tahun ke tahun terus mengalami peningkatan dari faktor kelahiran, datang, kematian dan pergi. Berdasarkan hasil Sensus Penduduk 2010, penduduk Kabupaten Badung berjumlah 388.514 jiwa yang terdiri dari 195.206 jiwa (50,27\%) laki-laki dan 193.308 jiwa (49,75\%) perempuan, sebagian besar penduduk bermukim di Kecamatan Mengwi 27,72\% (103,769 jiwa) dan Kecamatan Abiensemal 20,76\% (77,735 jiwa). Kecamatan Petang merupakan kecamatan yang jumlah penduduknya paling rendah, yakni 7,38\% (27,632 jiwa). Secara keseluruhan jumlah penduduk laki-laki lebih tinggi dibandingkan dengan penduduk perempuan seperti tampak dari rasio jenis kelamin penduduk yang lebih kecil dari 100. Dengan luas wilayah $418,52 \mathrm{~km}^{2}$, kepadatan penduduk Kabupaten Badung 928,30 jiwa/ $/ \mathrm{km}^{2}$. 
Pertumbuhan penduduk yang tinggi terjadi di Kecamatan Kuta selatan 9,11\%, Kuta 5,93\% dan Kuta Utara 6,94\%. Hal ini dimungkinkan karena pembangunan fisik perumahan dan sarana pariwisata sangat pesat di Kuta Selatan dan Kuta. Sedangkan Kuta Utara sebagai daerah penyangga dengan pembangunan perumahan dan pemukiman baru. Pertumbuhan terendah terjadi di Kecamatan Petang 0,37\%, sedangkan Mengwi 2,46\% dan Abiansemal 1,77\%. Badung Selatan dengan laju pertumbuhan penduduk cukup tinggi sudah tentu sangat memerlukan penataan administrasi kependudukan yang lebih baik.

\subsubsection{Kabupaten Buleleng}

Secara geografis wilayah Kabupaten Buleleng berada pada posisi $8^{\circ} 03^{\prime} 40^{\prime \prime}-8^{\circ} 23^{\prime} 00^{\prime \prime}$ LS dan 114 $25^{\prime} 55^{\prime \prime}-115^{\circ} 27^{\prime} 28^{\prime \prime}$ BT. Kabupaten Buleleng terletak di belahan utara Pulau Bali memanjang dari barat ke timur dan mempunyai pantai sepanjang $144 \mathrm{Km}$. Kabupaten Buleleng merupakan daerah berbukit yang membentang di bagian selatan, sedangkan di bagian utara merupakan dataran rendah. Di Kabupaten Buleleng juga terdapat gunung berapi dan tidak berapi. Gunung yang tertinggi adalah Gunung Tapak (1903 M) berada di Kecamatan Sukasada sementara yang paling rendah adalah gunung Jae $(222 \mathrm{M})$ berada di wilayah Kecamatan Gerokgak. Selain itu di Kabupaten Buleleng terdapat dua buah danau yaitu Danau Tamblingan (110 hektar) berada di Kecamatan Banjar. Sedangkan Danau Buyan (360 hektar) terletak di Kecamatan Sukasada.

Menyatunya ataupun relatif dekatnya antara wilayah pegunungan dengan pantai memberikan makna tersendiri bagi Kabupaten Buleleng dibandingkan dengan Kabupaten lainnya di Provinsi Bali. Kondisi yang khas ini menjadikan topografi wilayah Buleleng sering disebut Nyegara Gunung. Kabupaten Buleleng memiliki iklim tropis yang dipengaruhi oleh angin musim yang berganti setiap enam bulan. Buleleng termasuk pada daerah bayang-bayang hujan, dengan curah hujan berkisar antara bulan Oktober-April, sedangkan musim panas berkisar antara bulan April-Oktober. Kondisi Buleleng yang Nyegara Gunung, dimana di bagian selatan merupakan perbukitan dan pegunungan menjadi curah hujan ataupun intensitas hujan relatif lebih tinggi di wilayah Buleleng bagian selatan. Boleh dikatakan hampir tidak ada bulan-bulan kering terutama di sekitar Danau Tamblingan dan Danau Buyan.

\section{Batas Wilayah Administrasi}

Sebelah Utara : Laut Jawa/Bali.

Sebelah Timur : Kabupaten Karangasem.

Sebelah Selatan : Kabupaten Badung, Gianyar, Bangli dan Tabanan.

Sebelah Barat : Kabupaten Jembrana.

Kabupaten Buleleng berbatasan dengan Kabupaten Jembrana dibagian Barat, laut Jawa/Bali di Bagian Utara, dengan Kabupaten Karangasem dibagian Timur dan di sebelah Selatan berhadapan dengan 4 Kabupaten yaitu : Badung, Gianyar, Bangli, dan Kabupaten Tabanan. Luas Kabupaten Buleleng secara keseluruhan 1.365,88 $\mathrm{Km}^{2}$ atau $24,25 \%$ dari luas Propinsi Bali, dimana kecamatan Gerokgak merupakan kecamatan terluas yakni 26,11\%, 
Kecamatan Busungbiu seluas 14,40\%, Kecamatan Sukasada dan Banjar masing-masing 12,66\% dan 12,64\%. Kecamatan Kubutambahan sebesar 8,66\%, Kecamatan Seririt 8,18\%, Kecamatan Tejakula 7,15\%, Kecamatan Sawan 6,77\% dan Kecamatan Buleleng 3,44 \%.

Dalam rangka memudahkan dan meningkatkan koordinasi perencanaan maupun pelaksanaan pembangunan di seluruh wilayah Kecamatan sesuai karakteristik wilayahnya, Pemerintah Kabupaten Buleleng mengelompokkan sub wilayah pembangunan menjadi 3 yaitu:

a. Wilayah Pembangunan Buleleng Barat terdiri dari 4 kecamatan masing-masing yaitu Kecamatan Gerokgak dengan luas wilayah $356,57 \mathrm{Km}^{2}$, Kecamatan Seririt dengan luas wilayah 111,78 Km², Kecamatan Busungbiu dengan luas wilayah 196,62 $\mathrm{Km}^{2}$, Kecamatan Banjar dengan luas wilayah $172,60 \mathrm{Km}^{2}$. Pusat pertumbuhan dan perkembangan pada wilayah pembangunan Buleleng Barat ini adalah kecamatan/kota Seririt, dengan sub pusat pertumbuhan lainnya adalah Kota Kecamatan Gerokgak.

b. Wilayah Pembangunan Buleleng Tengah terdiri dari 2 kecamatan masing-masing yaitu Kecamatan Buleleng dengan luas wilayah $46,94 \mathrm{Km}^{2}$ dan Kecamatan Sukasada dengan luas wilayah $172,93 \mathrm{Km}^{2}$. Pusat pertumbuhan dan pengembangan wilayah pembangunan Buleleng Tengah ini adalah Kota Singaraja dan sub pertumbuhan lainnya terletak di Desa Pancasari.

c. Wilayah Pembangunan Buleleng Timur terdiri dari 3 kecamatan masing-masing Kecamatan Tejakula dengan luas wilayah 97,68 $\mathrm{Km}^{2}$, Kecamatan Kubutambahan dengan luas wilayah 118,24 $\mathrm{Km}^{2}$, Kecamatan Sawan dengan luas wilayah 92,52 $\mathrm{Km}^{2}$, Pusat pertumbuhan dan pengembangan wilayah pembangunan Buleleng Timur ini adalah Kota Kecamatan Kubutambahan / Desa Kubutambahan.

Pemerintah Kabupaten Buleleng secara administrasi terdiri dari 9 Kecamatan, 129 Desa, 19 Kelurahan, 63 Lingkungan, 535 Dusun/Banjar, dan 168 Desa Adat. Adapun 9 Kecamatan dimaksud yaitu : Kecamatan Tejakula, Kecamatan Kubutambahan, Kecamatan Seririt, Kecamatan Sawan, Kecamatan Buleleng, Kecamatan Busungbiu, Kecamatan Sukasada, Kecamatan Banjar, dan Kecamatan Gerokgak.

Administrasi Pemerintahan Kabupaten Buleleng

Tahun $2008-2010$

\begin{tabular}{|l|l|r|r|r|}
\hline \multirow{2}{*}{ Administrasi Pemerintahan } & \multirow{2}{*}{ SATUAN } & \multicolumn{3}{|c|}{ TAHUN } \\
\cline { 3 - 5 } & & 2008 & \multicolumn{1}{c|}{2009} & \multicolumn{1}{c|}{2010} \\
\hline Kecamatan & Kec & $9 \mathrm{kec}$ & $9 \mathrm{kec}$ & $9 \mathrm{kec}$ \\
\hline Desa & Desa & $129 \mathrm{desa}$ & $129 \mathrm{desa}$ & $129 \mathrm{desa}$ \\
\hline Kelurahan & Kel & $19 \mathrm{kel}$ & $19 \mathrm{kel}$ & $19 \mathrm{kel}$ \\
\hline Lingkungan & Lingk & $55 \mathrm{lingk}$ & $63 \mathrm{lingk}$ & $63 \mathrm{lingk}$ \\
\hline Dusun/banjar & Ds/bjr & $540 \mathrm{ds} / \mathrm{bjr}$ & $535 \mathrm{ds} / \mathrm{bjr}$ & $535 \mathrm{ds} / \mathrm{bjr}$ \\
\hline Desa adat & Desa adat & $166 \mathrm{ds}$. adat & $168 \mathrm{ds}$. adat & $168 \mathrm{ds}$. adat \\
\hline
\end{tabular}

SUMBER : BPMPD Kab. Buleleng, 2010

\subsubsection{Kabupaten Karangasem}


Wilayah Kabupaten Karangasem secara geografis terletak $8^{\circ} 00^{\prime} 00^{\prime \prime}-8^{\circ} 41^{\prime} 37,8^{\prime \prime}$ LS dan $115^{\circ} 35^{\prime} 9,8^{\prime \prime}-115^{\circ} 54^{\prime} 8,9^{\prime \prime}$ BT dengan luas daerah 839,54 $\mathrm{Km}^{2}$ atau $14,90 \%$ dari luas Propinsi Bali $\left(5.632,86 \mathrm{Km}^{2}\right)$. Kabupaten Karangasem mempunyai curah hujan sedang, dengan tingkat kesuburan tanah yang sedang dan hampir sebagian tanah di daerah ini ditutupi oleh pasir/material hasil letusan Gunung Agung. Kabupaten Karangasem mempunyai iklim tropis yang sangat dipengaruhi oleh angin musim dan memiliki 2 (dua) musim yaitu musim kemarau dan musim hujan. Jenis tanah di wilayah Kabupaten Karangasem didominasi oleh tanah regosol dan tanah latosol. Khususnya di daerah dataran tinggi sebagian besar terbentuk dari tanah jenis andosol.

\section{Batas Wilayah Administrasi}

Sebelah Utara : Laut Jawa.

Sebelah Timur : Selat Lombok.

Sebelah Selatan: Samudera Indonesia.

Sebelah Barat : Kabupaten Klungkung, Bangli dan Buleleng.

Secara keseluruhan luas wilayah Kabupaten Karangasem adalah 839,54 km² yang terbagi dalam 8 Kecamatan dengan luas masing - masing kecamatan sebagai berikut :

Luas Wilayah Per Kecamatan di Kabupaten Karangasem

\begin{tabular}{|c|l|c|c|}
\hline NO & KECAMATAN & LUAS WILAYAH $(\mathrm{km} 2)$ & PROSENTASE (\%) \\
\hline 1 & Rendang & 109,70 & 13,07 \\
\hline 2 & Sidemen & 35,15 & 4,19 \\
\hline 3 & Manggis & 69,83 & 8,32 \\
\hline 4 & Karangasem & 94,23 & 11,22 \\
\hline 5 & Abang & 134,05 & 15,97 \\
\hline 6 & Bebandem & 81,51 & 9,71 \\
\hline 7 & Selat & 80,35 & 9,57 \\
\hline 8 & Kubu & 234,72 & 27,96 \\
\hline \multicolumn{2}{|r|}{ JUMLAH } & $\mathbf{8 3 9 , 5 4}$ & $\mathbf{1 0 0}$ \\
\hline \multicolumn{2}{r}{ Sumber Data : BPS Kab. Karangasem, 2010} & \\
\end{tabular}

Kabupaten Karangasem tahun 2010 terdiri dari 8 Kecamatan, 3 Kelurahan, 75 desa, 581 Banjar Dinas/Lingkungan, 190 Desa Adat dan 605 Banjar Adat. Untuk menjalankan roda pemerintahan di masing-masing tingkat wilayah dikepalai oleh seorang Camat untuk tingkat kecamatan, Lurah/Kepala Desa untuk tingkat Kelurahan/Desa, Kepala Lingkungan untuk tingkat lingkungan dan Kelian Banjar untuk tingkat Banjar Dinas. 


\subsection{Tipologi dan Akar Permasalahan}

\subsubsection{Provinsi Jambi}

Tabel 1. Tipologi Permasalahan di Kanwil BPN Provinsi Jambi

\begin{tabular}{|l|l|l|l|}
\hline No. & TIPOLOGI & Jumlah & $\%$ \\
\hline 1 & Masalah Penguasaan dan Pemilikan Tanah & 177 & 70,52 \\
\hline 2 & Masalah batas/letak bidang tanah & 34 & 13,54 \\
\hline 3 & Masalah prosedur Penetapan Hak \& Pendaftaran Tanah & 31 & 12,35 \\
\hline 4 & Masalah pelaksanaan putusan pengadilan & 1 & 0,39 \\
\hline 5 & Masalah tanah ulayat & 4 & 1,59 \\
\hline 6 & Masalah tanah obyek Landreform & 3 & 1,19 \\
\hline 7 & Masalah ganti rugi tanah ex. Partikelir & 1 & 0,39 \\
\hline 8 & Masalah pengadaan tanah & - & - \\
\hline Jumlah & 251 & 100 \\
\hline
\end{tabular}

Selain masalah tersebut di atas, masih ada masalah lain yaitu :

a. Batas administrasi wilayah yang belum tegas (penetapan batas);

b. Adanya pemekaran wilayah yang tidak diikuti dengan penegasan batas wilayah;

c. Toponimi yang belum dibakukan

d. Adanya anggapan masyarakat tertentu bahwa tanah negara hanya dikuasai/dimiliki oleh masyarakat wilayah tersebut.

e. Adanya keterangan tanah (sporadik) yang tidak sesuai dengan kondisi fisik tanah atau letak tanah.

f. Penggunaan dan pemanfaatan tanah tidak sesuai dengan sifat dan pemberian haknya.

g. Terjadinya kecemburuan sosial di bidang pertanahan.

h. Anggota kelompok tani tidak percaya kepada pengurus koperasi. 
Dari tabel di atas menunjukkan tipologi permasalahan yang paling banyak terjadi di wilayah ini adalah penguasaan/pemilikan tanah.

Berdasarkan validasi data tahun 2010, diketahui jumlah :

Sengketa : 134 kasus

$>$ Konflik : 25 kasus

$>$ Perkara : 92 kasus

$>$ Total kasus : 251 kasus

Hal di atas menunjukkan jumlah/kuantitas konflik paling rendah dibandingkan perkara dan sengketa.

Para pihak yang terkait dalam konflik tersebut, antara lain :

Badan Hukum dengan masyarakat

$>$ Masyarakat dengan Masyarakat ; jumlahnya sedikit

$>$ Masyarakat dengan Instansi Pemerintah

Tabel.2 Data konflik 2007-2010

\begin{tabular}{|r|l|c|c|c|c|}
\hline \multirow{2}{*}{$\begin{array}{l}\text { No } \\
\text {. Kantor Pertanahan }\end{array}$} & \multicolumn{5}{|c|}{ Konflik } \\
\cline { 2 - 6 } & & 2007 & 2008 & 2009 & 2010 \\
\hline 1. & Kabupaten Muaro Jambi & - & 3 & 2 & 3 \\
\hline 2. & Kabupaten Batanghari & & & & \\
\hline 3. & Kota Jambi & - & 4 & 6 & 7 \\
\hline & & & & & \\
\hline
\end{tabular}

\subsubsection{Kabupaten Muaro Jambi}

Bapak Mujahidin, ${ }^{9}$ Kepala Kantor Pertanahan Muora Jambi, mengungkapkan beberapa kendala dalam penyelesaian konflik pertanahan. Antara lain:

a. Dana ditentukan sama tidak memperhitungkan besar kecilnya volume. Pendanaan juga menimbulkan pertanyaan, apakah setiap kasus penyelesaiannya dengan pembayaran; Lalu siapa yang harus membayar pengeluaran di obyek sengketa, pembayaran tersebut hanya untuk biaya transpor atau masuk kas negara sebagai Pendapatan Negara Bukan Pajak, dan jika menjadi PNBP apa produknya, karena yang tumpang tindih bukan sertifikatnya tapi garapannya.

${ }^{9}$ Diskusi di Kanwil BPN Jambi dan di Kantor Pertanahan Muaro Jambi, 13 April 2011 
b. Ketidaksinkronan antar seksi;

c. Ketidaktegasan dalam mengamankan sertifikat;

d. Ketidakuatan seksi konflik pertanahan menghadapi tekanan;

e. Lemahnya pemahaman seksi konflik pertanahan terhadap Peraturan Kepala BPN tentang Pennyelesaian Konflik Pertanahan;

f. Bagaimana menghubungkan persoalan pertanahan dengan HAM.

Konflik pertanahan di Muaro Jambi disebabkan oleh perkembangan masyarakat menjadi pekebun, dahulu batas wilayah tidak jelas, untuk menggarap lahan dahulu harus berombongan untuk mencegah babi hutan, dan dahulu gubernur mengundang perusahaan-perusahaan untuk menggarap lahan. Perkembangan masyarakat menjadi pekebun inilah yang menimbulkan konflik pertanahan karena menganggap tanahnya masuk areal perusahaan.

Konflik antara Masyarakat dan Badan hukum di Muaro Jambi adalah kasus PT Kirana Sakernan yang semula namanya Brahma Bina Bakti, sekarang berubah lagi menjadi PT Brahma Bina Bakti. Akar masalahnya karena ada pengaduan masyarakat desa tanjung lanjut yang memohon pengembalian lahan perkebunan kelapa sawit seluas 2100 ha yang dikuasai PT Kirana Sekernan sejak tahun 2001. Adapun yang dipermasalahkan adalah tanah HGU PT Kirana Sekernan. Perkembangan terakhir tahapan penyelesaiannya berdasarkan hasil mediasi tanggal 25 Oktober 2010 akan dilakukan identifikasi melalui citra satelit dan ground truth terhadap batas HGU maupun inventarisasi penguasaan dan pemilikan tanah masyarakat yang dienclave dalam HGU. Konflik di daerah ini juga disebabkan karena tidak adanya batas desa, seperti yang terjadi pada kkasus PT Kirana Sakernan di atas, BPN mengatakan itu termasuk desa Bukit Baling namun masyarakat mengatakan itu termasuk desa Tanjung Lanjut, sampai hari ini belum dilakukan pengukuran.

Lebih lanjut, dari diskusi dengan Bapak Kakanwil Provinsi Jambi, diperoleh keterangan bahwa sumber dari konflik pertanahan disebabkan oleh cara pandang di BPN tentang kebenaran formal, bukannya kebenaran material. Misalnya di data yuridis yaitu perijinan. Ijin lokasi bersumber dari tata ruang; Analisasi Mengenai Dampak Lingkungan (Amdal) oleh Dinas Lingkungan Hidup; Ganti rugi pelepasan hak oleh Dinas Perkebunan dan terakhir Ijin Usaha Perkebunan. Sedari awal proses tersebut tidak melibatkan BPN, padahal jika secara formal terpenuhi maka BPN akan mengeluarkan HGU, sehingga yang formal tadi bisa jadi ada masalah ganti rugi yang belum tuntas. Sehingga ketika HGU diterbitkan ternyata ada penolakan warga.

Penolakan warga biasanya berupa spontanitas massa yang kemudian didampingi LSM (NGO) mengadu ke Pemerintah baik melalu aksi demonstrasi maupun surat pengaduan.

\subsubsection{Kabupaten Batanghari}

Ada beberapa konflik yang belum bisa terselesaikan, yaitu kasus : 
1. PT Asiatic Persada dengan 235 KK ( Plasma PTP Nusantara VI) yang berada di HGU PT Asiatic Persada

PT Asiatic Persada memiliki HGU sebesar 20.000 ha yang di dalamnya tinggal Suku Anak Dalam. 1. 000 ha dimitrakan dengan Suku Anak Dalam yang diatur melalui Peraturan Gubernur. Kemitraan ini dimanajemen lewat "Koperasi Sangat Mandiri” yang dibina oleh Pemda dalam hal ini Dinas Koperasi. Untuk supaya tepat sasaran, masyarakat yang mengaku Suku Anak Dalam diseleksi keasliannya dengan melihat keturunan dan sejarah oleh tetua-tetua adat Suku Anak Dalam

2. PT Asiatic Persada dengan Suku Anak dalam (SAD)

PT Asiatic Persada memiliki HGU sebesar 20.000 ha yang di dalamnya tinggal Suku Anak Dalam. Hasil mediasi oleh Pemkab/Pemprov, telah ada kesepakatan tahun 2009 bahwa pihak perusahaan menyerahkan areal kebun kelapa sawit seluas 1. 000 ha dimitrakan dengan Suku Anak Dalam yang diatur melalui Peraturan Gubernur. Kemitraan ini dimanajemen lewat "Koperasi Sangat Mandiri" yang dibina oleh Pemda dalam hal ini Dinas Koperasi. Untuk supaya tepat sasaran, masyarakat yang mengaku Suku Anak Dalam diseleksi keasliannya dengan melihat keturunan dan sejarah oleh tetua-tetua adat Suku Anak Dalam.

3. PT. Tunjuk Langit Sejahtera dengan petani plasama

Tipologi masalah $=$ Penetapan hak dan Pendaftaran tanah

Akar masalah, sertipikasi untuk wilayah KUD Sri Harapan telah diselesaikan, sedangkan sertipikasi untuk KUD Bangun Mitra belum bisa dilaksanakan karena belum memenuhi syarat yuridis (sporadik) kepemilikan tanah.Pola kemitraan dilaksanakan pada tahun 1994/1995 menyangkut 8500 ha dengan proporsi $30 \%$ untuk perusahaan dan $70 \%$ untuk masayarakat, dalam pelaksanaannya ada masalah, karena ada kebun yang belum siap diserahkan akibat tanam tumbuhnya tidak sesuai dan ada petani yang belum mendapat kebun.

Dilihat dari inti persoalan bukan merupakan ranah BPN (BPN hanya mengurus tanah yang sudah terdaftar).

4. $\quad$ PT SDM (pemegang HGU) dengan masyarakat yang mengokupasi (terindikasi terlantar)

Luas HGU 14.225 ha, melakukan program inti murni, HGU ini kemudian terindikasi terlantar, hampir $40 \% \mathrm{HGU}$ diterlantarkan, ada yang diokupasi masyarakat dengan ditanami karet, ada juga hutan yang belum terbuka. Sekarang perusahaan ingin mengusahakan HGU nya, tapi terbentur dengan tanah yang diokupasi oleh masyarakat. Saat ini sedang dilakukan mediasi, dan menunggu kebijakan BPN mengenai tanah terlantar.

Menurut Ibu Sri Noviyana, Kepala Seksi Konflik Pertanahan Kantor Pertanahan Batanghari, kendala dari mediasi adalah Perusahaan sering ingkar janji dan sumber daya manusia di Kantor Pertanahan Batanghari belum memadai.

Di kabupaten Batanghari konflik pertanahan terbesar adalah antara Badan Hukum dengan masyarakat, persoalannya meliputi HGU dan proses kerjasama kemitraan. 
Berdasarkan Peraturan Pemerintah Nomor 38 Tahun 2007, ada 9 item tugas BPN yang diserahkan ke Pemda yang kemudian menjadi tugas pokok Asisten I dan Asisten II, beberapa diantaranya adalah Tata ruang, Hak ulayat, Pembukaan lahan, Konflik pertanahan, dan lain-lain

Di Batanghari, Asisten I membentuk tim yang bersifat insindental untuk menyelesaikan konflik pertanahan secara mediasi. Selain itu ada pula Tim Pengawasan, Pembinaan dan Penyelesaian Permasalahan Perkebunan.

\subsubsection{Kota Jambi}

Responden menjelaskan upayanya meminimalisir konflik pertanahan secara litigasi. Untuk itu Kantah Kota Jambi mengedepankan alternatif penyelesaian masalah secara non litigasi yaitu melalui mediasi. Dan dari puluhan konflik pertanahan yang dimediasi oleh Kantah Kota Jambi tersebut, hanya ada dua kasus yang tidak tercapai kesepakatan sehingga dilanjutkan ke Pengadilan. Kebijakan ini diambil karena dengan mediasi kasus lebih cepat selesai, biaya lebih murah, dan tanah bisa lebih cepat diakses.

Sebelum dilakukan mediasi, harus dilakukan upaya Pra Mediasi, dimana Kantah Kota Jambi mencari data dan saksi serta menyusun analisa permasalahan. Setelah itu baru proses mediasi yang ditarget selesai dengan tiga kali pertemuan.

Kendala dari mediasi ini antara lain

Jika BPN tidak dalam posisi netral;

$>$ Jumlah SDM Kantah yang tidak memadai, karena setiap bulannya ada empat ribu permohonan pelayanan pertanahan, lima kasus pertanahan, dan belum termasuk pelaksanaan progam Prona, P4T dan Konsolidasi Tanah.

$>$ Bagaimana agar kesepakatan yang sudah disetujui oleh para pihak yang bersengketa di taati sehingga bisa langsung dilaksanakan

\subsubsection{Provinsi Sulawesi Utara}

\subsubsection{Di Kota Manado}

Diperoleh berbagai gambaran mengenai konflik yang terjadi di wilayah ini, yang umumnya merupakan kasus lama dan sampai saat ini belum terselesaikan, yaitu :

4. Kasus Saptamarga antara TNI versus 130 Pensiunan. Obyek sengketa adalah bekas Hak Barat (Eigendom) yang selama ini dihuni oleh para Veteran Trikora. TNI berpegang pada Undang-Undang No. 1 Tahun 2004, bahwa asetnya ini masuk dalam Inventaris Kekayaan Milik Negara (IKMN), sedangkan para pensiunan meminta sertifikat hak milik atas nama pribadi-pribadi, yang mana permohonan sertikat ini ditolak BPN. Konflik kemudian 
menjadi antara BPN dengan pensiunan ketika para pensiunan ini memperkarakan penolakan permohonan sertikat ini ke Pengadilan Tata Usaha Negara (PTUN) hingga Mahmakah Agung (MA).

Putusan MA menyatakan: (1). Surat Keputusan Kantor Pertanahan tentang penolakan permohonan sertifikat dinyatakan tidak sah; (2). TNI tidak bisa membuktikan bahwa tanah tersebut adalah asetnya.

Kantor Pertanahan Kota Manado tetap tidak berani mengeluarkan sertfikat, dan meminta petunjuk dari dari BPN Pusat, tetapi hingga kini belum ada tanggapan. Padahal sekarang Kantor Pertanahan Kota Manado juga disurati oleh Komisi Nasional Hak Asasi Manusia (Komnas HAM), karena para pensiunan mengadukan permasalahan ini ke Kantor Komnas HAM di Jakarta.

5. Kasus Perorangan versus masyarakat (Kasus Maskeret), yaitu tanah konversi hak barat yang diokupasi warga semenjak tahun 1960. Putusan pengadilan menyatakan konversi hak barat tersebut adalah sah. Putusan Gelar Perkara di BPN Pusat merekomendasikan Kanwil BPN Sulut atau Kantah Kota Manado menjadi mediator, karena konversi sah (masyarakat tidak bisa membatalkan hak). Namun Notulen Gelar Perkara berbunyi konversi tidak sah.

Dari dua kasus tersebut, kapasitas penyelesaian konflik pertanahan BPN dalam hal ini Kantah Kota Manado menghadapi kendala berupa:

(1). Ketiadaan satu bahasa;

(2). Ketiadaan Petunjuk;

(3). Ketiadaan perlindungan hukum dari instansi;

(4). Tidak sesuai dengan volume anggaran;

(5). Terbawa peraturan perundangan instansi lain, padahal UUPA 1960 sebagai landasan hukum BPN lebih tua dibandingkan peraturan perundangan instansi lain yang terkait pertanahan.

Reklamasi pantai di Kota Manado, juga menimbuklan konflik pertanahan. Status tanah hasil reklamasi berupa Hak Pengelolaan (HPL) diperoleh Pemda. Dalam konflik pertanahan tersebut BPN memediasi konflik antara Pemda dengan pengembang. Konflik ini bersumber dari besaran porsi tanah yang dikuasai Pemda dengan pengembang.

\subsubsection{Di Kota Bitung}

1. Konflik pertanahan terbesar adalah di eks Hak Guna Usaha (HGU). Dari 5 eks HGU, 3 berkonflik, dan 1 sengketa antara pemegang hak dengan Pemkab. Yang dapat dijadikan contoh di sini adalah ketika HGUnya mau habis, si pemilik HGU ke masyarakat. Oleh BPN dikeluarkan sertfikat, sertikat di eks HGU juga dibagikan ke Pemda dan koperasi karyawan Kanwil BPN. Namun kelompok masyarakat lain menolak sertfikat tersebut dan memperkarakan ke PTNU serta menduduk lahan eks HGU tersebut, kemudian memicu terjadinya konflik fisik. Artinya secara yuridis dikuasasi para pemegang hak, namun secara fisik dikuasai masyarakat penggarap.

Bahwasanya, berdasarkan Peraturan Kepala BPN (Perkaban), prioritas redistribusi tanah eks HGU antara lain : (1). Yang punya HGU lama; (2). Pemerintah Kabupaten; (3). Masyarakat sekitar; (4). Bekas buruh perkebunan tersebut; (5). Koperasi BPN. 
Konflik pertanahan di eks HGU disebabkan oleh beberapa faktor:

(1). Celah hukum. Pemegang hak, HGUnya belum habis (kurang dua tahun, dimana seharusnya hak-haknya telah hilang), tetapi masih menginginkan hak, ada Peraturan Pemerintah yang memungkinkan masih punya hak perdata. Ada juga HGU tidak diperpanjang tapi juga tidak perbarui (Se-Sulawesi Utara ada 70 kasus);

(2). Siapa yang mengatur peruntukan eks HGU;

(3). Tidak ada yang menyerap aspirasi masyarakat, karena Dinas Perkebunan ada di Pemerintah Provinsi, sedangkan tanah ada di Pemkab/Pemkot;

2. Contoh konflik pertanahan yang lain adalah Pertamina versus masyarakat. Meski putusan pengadilan menyatakan Pertamina harus keluar dari lahan dan membayar ganti rugi. Pertamina tidak mau keluar lahan dan terus menegosiakan angka ganti rugi.

Obyek konflik tanah seluas 4,5 ha, yang dikuasai Pertamina semenjak tahun 1967, dan kini diguggat oleh 300 orang ahli waris. Pada tahun 2009 coba dimediasi, tapi tidak ada titik temu sehingga ahli waris membikin tenda simbol perlawanan di depan depo Pertamina di lokasi konflik. Tuntutan warga ini diperkuat putusan pengadilan. Putusan pengadilan bersumber pada sertifikat tanah Pertamina yang tanpa Surat Ukur, hanya gambar desa.

3. Konflik pertanahan juga terjadi di pulau kecil, yang bernama pulau Lembeh (5.040 ha). Awalnya tanah tersebut adalah Tanah Adat (Pasini), kemudian oleh Pemerintah Kolonial Hindia Belanda, pengelolaannya diserahkan kepada satu orang.

Pada tahun 1988, keluarlah Surat Keputusan Menteri Dalam Negeri dijadikan Tanah Negara, berdasarkan pertimbangan Panitia landreform. Kemudian diredistribusikan untuk berbagai macam peruntukan yang tidak ada peta peruntukannya yang seharusnya dibikin oleh Pemda. Kemudian BPN melakukan pensertifikatan secara sporadis yang tidak ada peta peruntukannya dan 1.000 ha pulau tersebut dinyatakan sebagai hutan lindung. Namun warga menuntut 300 ha berdasarkan SK Mendagri.

Pulau tersebut kini dibagi menjadi 2 kecamatan dan 17 kelurahan, dengan ahli waris yang menuntut 300 ha tersebut sebanyak 16.000 orang, yang terdiri dari 2 keluarga besar yang tidak akur. Setiap Pemilu, kandidat peserta Pemilu selalu menjanjikan penyelesaian konflik ini. BPN Pusat pernah fasilitasi mediasi antara instansi pemerintah dengan masyarakat, yang keputusannya adalah pemetaan, tetapi tidak jelas siapa yang harus memetakan. Di pesisir Bitung, di Selat Lembeh, ada juga eks HGU yang dikuasasi satu orang, dan orang inilah yang meredistribusikan lahan dan menjual lahan.

\subsubsection{Di Kabupaten Minahasa Utara}

1. Konflik pertanahan di desa Wori Kecamatan Wolo terjadi di tanah bekas HGB dan HGU yang kini secara fisik diduduki masyarakat.

2. Sedangkan di kecamatan Kema konflik pertanahan bersumber dari hak milik asal konversi yang tidak dicek secara fisik, penyelesaian dilakukan secara parsial melalui mekanisme jual beli.

3. Konflik di desa likupang terjadi pada awalnya berdasarkan kutipan register tanah desa likupang tahun 1914 persil No. 211, folio No. 65, luasnya \pm 685 ha, tertulis atas nama lemuel Mantiri, satu-satunya ahli waris dari Lambertus Mantiri. Kemudian pada tahun 
1933 tanah tersebut dimiliki oleh Louis Mantiri, Wellem Mantiri, Christina Mantiri (para ahli waris/anak-anak dari Lambertus Mantiri dan Calesina Bojoh (suami istri).

Pada tahun 1965 tanah tersebut terkena Undang-Undang No. 56/Prp/1960 dan dinyatakan dikuasai negara berdasarkan Surat keputusan panitia Landreform Daerah Tk II Minahasa tgl 25 januari 1965 No. SK/XVI/149/I/1965.

Dari luas tanah tersebut terdapat 2 desa areal permukiman yaitu Desa Maen dan desa Wineru yang sudah ada sebelum tahun 1929, kemudian lokasi tanah tersebut seluas $450 \mathrm{Ha}$ dikuasai oleh PT Dinealator Likupang Beach yang telah dijadikan obyek pariwisata dengan berdirinya hotel dan sarana penunjang lainnya. Masyarakat Desa Maen dan desa Wineru menganggap bahwa ahli waris Louis Mantiri dan jacoba Maringka tidak lagi berhak atas tanah tersebut karena mereka sudah menduduki dan menguasai tanah itu turun temurun.

Konflik antar masyarakat juga terjadi, meliputi kasus-kasus tapal batas dan waris, yang dapat diselesaikan lewat mediasi dengan pendekatan kearifan asli, yaitu Hukum Tua (Kades), pendekatan agama, dan pendekatan kemanusiaan.

\subsubsection{Provinsi Banten}

Konflik yang terjadi di Provinsi Banten tersebar di beberapa kabupaten dan tipologi permasalahan pada umumnya adalah mengenai penguasaan/pemilikan tanah.

\subsubsection{Kabupaten Lebak}

1. Terjadinya pembebasan tanah untuk waduk karian seluas 217 ha pada tahun 2007 yang menimbulkan sengketa antara PTP VIII(HGU) versus masyarakat. PTP VIII melanjutkan HGU PT Kargo yang mempunyai perjanjian dengan masyarakat untuk menggarap kemudian PT Kargo dialihkan ke PT Linggar sari, lalu dialihkan lagi ke PTP VIII dan sampai saat ini belum balik nama. Sebenarnya HGU sudah berakhir tahun 2005 sewaktu masih dikuasai oleh PT Linggar sari, akhirnya Pemkab Lebak, yang membebaskan tanah mengalami kesulitan pembayaran ganti rugi harus ke pihak mana.

2. Adanya konflik pertanahan antara petani penggarap dengan PT Bantam. Menurut Serikat Petani Indonesia (SPI) yang mewakili petani penggarap, kepada Kanwil BPN Provinsi Banten menyatakan bahwasanya HGU telah berakhir dan tanah tidak dimanfaatkan oleh perusahaan, sehingga kemudian digarap oleh petani. Tuntutan SPI adalah perpanjangan HGU ditolak dan tanah yang digarap petani diredistribusikan kepada para petani penggarap.

Sedangkan menurut Kantor Pertanahan Kabupaten Lebak, bahwasanya perusahaan tidak menelantarkan dan HGU sudah mengajukan perpanjangan HGU. Namun karena konflik, maka permohonan perpanjangan tidak diproses. Adapun kondisi di lapangan, masyarakat sudah mematok tanah yang masih produktif tersebut.

\subsubsection{Kabupaten Pandeglang}


Konflik pertanahan di Taman Nasional Ujung Kulon (TNUK).

Sejak jaman Belanda, wilayah yang saat ini dikukuhkan menjadi Taman Nasional Ujung Kulon (TNUK) telah didiami oleh warga 6 desa (Desa Ujung Jaya, Taman Jaya, Cigorondong, Tunggal Jaya, Kerta Mukti dan Kertajaya) di Kecamatan Sumur, Pandeglang, Banten. Keenam desa tersebut merupakan hasil pemekaran dari desa Cigorondong pada tahun 1977.

Keberadaan masyarakat desa Ujung Jaya yang terdiri dari 5 kampung: Cikawung Sabrang, Legon Pakis, Cikawung Girang, Sempur, Taman Jaya Girang telah berlangsung turun temurun dengan mengandalkan penghidupannya dari mengolah lahan pertanian (sawah dan kebun). Sebagian besar penduduk hingga saat ini menjadi petani. Dari penuturan masyarakat, Kampung Cikawung Girang, Legon Pakis, Cikawung Sabrang merupakan hadiah (upah kerja) dari Pemerintah Kolonial Belanda setelah masyarakat melaksanakan kerja pembuatan Lapangan Banteng dan jalan.

Secara administratif, desa Ujung Jaya merupakan hasil dari pemekaran desa Taman Jaya pada tahun 1982. terdiri dari 3.641 jiwa dengan 869 kepala keluarga, luas desa mencapai 900 Ha, termasuk tanah yang diserobot oleh TNUK.

Ujung Kulon diakui memiliki keanekaragaman hayati flora dan fauna. Atas dasar itu kemudian pada tahun 1921, Ujung Kulon dan Pulau Panaitan ditetapkan oleh Pemerintah Belanda sebagai Cagar Alam Ujung Kulon-Panaitan Melalui SK. Pemerintah Belanda No. 60 tanggal 16 Nopember 1921.

Tahun 1932 diadakan pengukuran tanah oleh Belanda di Ujung Kulon yang dibuktikan melalui Peta Tanah Milik (PTM) tahun 1935. Kepada warga yang menempati lahan di Desa Ujung Jaya pada saat itu diberikan surat kepemilikan tanah berbentuk Girik (cap singa) bagi masyarakat.

Tahun 1937, Status Cagar Alam Ujung Kulon-Panaitan diubah menjadi Suaka Margasatwa Ujung Kulon-Panaitan oleh Pemerintah Kolonial Belanda melalui Keputusan No. 17 Juni 1937.

Tahun 1958 oleh Kantor Tjabang Pendaftaran Tanah Milik Serang dikeluarkan Surat Tanda Pendaftaran Tanah Milik Indonesia yang dibuktikan melalui sertifikat cap Garuda.

Sejak tahun 1965 masyarakat telah mendapatkan Bukti Surat Pembayaran Pajak Hasil Bumi dari aktivitas pengolahan lahan pertanian dari Kantor Padjak Tjabang Serang. Pada tahun yang sama, status Kawasan berubah kembali menjadi Kawasan Suaka Alam berdasarkan SK. Menteri Pertanian No. 48/UM/1958 tertanggal 17 April 1958 dengan memasukkan kawasan perairan laut selebar 500 Meter dari batas air laut surut terendah Semenanjung Ujung Kulon, dan memasukan pulau-pulau kecil disekitarnya seperti Pulau Peucang, Pulau Panaitan, dan pulau-pulau Handeuleum (Pulau Boboko, pulau Pamanggan).

Tahun 1967 melalui SK Menteri Pertanian No. 16/KPTS/UM/3/1967 tanggal 16 Maret 1967, kawasan Cagar Alam Ujung Kulon diperluas dengan memasukan Gunung Honje Selatan seluas 10.000 hektar. Perluasan areal tersebut juga membuat pemukiman warga sejumlah desa menjadi bagian dari Kecamatan Sumur.

Tahun 1979, area kawasan Cagar Alam Ujung Kulon kembali diperluas. SK. Menteri Pertanian No. 39/KPTS/UM/1979 tanggal 11 Januari 1979 memasukkan lahan seluas 9.498 hektar di Gunung Honje sebelah Utara yang didiami penduduk yang terbagi beberapa desa di kecamatan Cimanggu kedalam kawasan Cagar Alam. 
Tahun 1984, Cagar Alam Ujung Kulon yang tadinya di kelola oleh Kehutanan (biasa disebut masyarakat sebagai Bohir) berubah dengan dibentuknya Taman Nasional Ujung Kulon melalui SK Menteri Kehutanan No. 96/KPTS/II/1984 yang wilayahnya meliputi: Semenanjung Ujung Kulon seluas 39.120 Ha, Gunung Honje seluas 19.498 Ha, Pulau Peucang dan Panaitan seluas 17.500 Ha, Kepulauan Krakatau seluas 2.405,1 Ha, dan hutan Wisata Carita seluas 95 Ha.

Perubahan bentuk pengelolaan kawasan mulai menimbulkan ketegangan. Pengukuhan wilayah taman nasional menjadikan sejumlah desa di kecamatan Cimanggu dan Sumur masuk pada wilayah kawasan Taman Nasional Ujung Kulon.

Kampung Legon Pakis dan beberapa kampung lainnya serta areal perkebunan/sawah milik masyarakat yang merupakan kawasan pemukiman yang berada dalam zona kelola masyarakat dalam kawasan taman nasional menjadi pemukiman yang mula-mula akan direlokasi.

Perubahan tapal batas taman nasional membuat perubahan pula pada penempatan Pos Jaga Suaka. Yang awalnya berada di Cilintang, dimana disana telah dibuat batas wilayah secara bersama oleh warga dan petugas Suaka, juga ikut dipindahkan. Menurut masyarakat Legon Pakis, seharusnya batas wilayah antara TNUK dengan lahan masyarakat berada di sebelah timur: Cipakis, sebelah barat: cilintang dan sebelah selatan: cihujan.

Masyarakat Legon Pakis sejak itu dipaksa pindah ke Kampung Pamatang Laja. Namun masyarakat tidak bersedia pindah, karena objek relokasi sangat jauh dari tempat asal, tidak terdapat areal pertanian/sawah untuk penghidupan masyarakat dan tanah tidak dapat ditanami.

Sejak saat itu, masyarakat yang berdiam diwilayah yang diclaim sebagai kawasan taman nasional mengalami intimidasi, kekerasan dari petugas Taman Nasional. Pengadaan listrik secara swadaya tidak diperbolehkan, masyarakat dilarang menebang tanaman kayu untuk kebutuhan sehari-hari, pekerjaan mengolah lahan juga terganggu, lahan pertanian, saung dan kebun warga dirusak. Masyarakat dituduh melakukan perambahan hutan dan ditangkap.

Di Legon Pakis, dari $155 \mathrm{KK}$, jumlah penduduk menyusut menjadi $85 \mathrm{KK}$ akibat masyarakat dilarang menebang pohon yang ditanamnya, dilarang membangun rumah (jumlah rumah dilarang bertambah), sekolah madrasah swadaya masyarakat ditutup, dan bahkan perbaikan mesjid yang telah berdiri sejak tahun 1950an harus melalui perundingan yang alot.

Pada tanggal 26 Pebruari 1992, Ujung Kulon ditetapkan menjadi Taman Nasional Ujung Kulon (TNUK) melalui SK Menteri Kehutanan No. 284/Kpts-II/1992, dengan luas areal 120.551 Ha. Pada tahun yang sama Komisi Warisan Dunia dari UNESCO menetapkan TNUK sebagai World Heritage Site dengan Surat Keputusan No. SC/Eco/5867.2.409.

Semenjak dinyatakan sebagai taman nasional, kegiatan-kegiatan Kantah Kabupaten Pandegelang belum bisa bisa dijalankan karena masuk kawasan yang dikelola Perhutani, Cikeusik, dan beberapa tempat lainnya. Bahkan, menurut bapak Khaerudin, Kepala Subseksi Konflik Pertanahan Kantor Pertanahan Kabupaten Pandeglang, DIPA (Dokumen Isian Pelaksanaan Anggaran) Kantah Pandeglang, anggarannya tidak bisa keluar karena terindikasi masuk kawasan hutan Kali Alas.

Di dalam konflik pertanahan di wilayah kehutanan, Kantor Pertanahan biasanya melakukan konfirmasi kepada Perhutani, namun biasanya Perhutani tidak memberikan informasi, dan terhadap konflik pertanahan di wilayah kehutanan, Perhutani kebijakannya tidak jelas, apakah dienclave atau resettlement. 
Pemda memiliki inisiatif guna menyelesaikan konflik pertanahan di wilayah kehutanan, terakhir Pemkab Pandegelang mengundang lintas instansi guna mencari penyelesaian konflik pertanahan di wilayah kehutanan, hasilnya pertemuan tersebut adalah penduduk dikeluarkan dari wilayah hutan, untuk itu perlu pendataan, padahal dalam persepsi penduduk, mereka sah menempati lahan karena membayar SPPT PBB (Surat Pemberitahuan Pajak Terutang Pajak Bumi dan Bangunan).

Menurut bapak Kakan Pandegelang, solusi untuk konflik pertanahan di wilayah kehutanan adalah enclave dan relokasi penduduk dengan memperhatikan kebutuhan pemukiman dan penghidupan masyarakat. Kemudian diberi tanda-tanda batas hutan yang jelas, karena ada kasus di mana ladang masuk hutan dan tegakan hutan di ladang masyarakat.

\subsubsection{Kabupaten Tangerang}

Di wilayah Kabupaten Tangerang konflik yang dominan adalah masalah permohonan sehingga trend mediasi terus naik, hal ini ditandai dengan selalu ada permintaan mediasi. Kasus sengketa pertanahan yang dimediasi melahirkan kesepakatan, hal ini disebabkan karena petugas yang memiliki pengalaman, petugas memahami karakter masyarakat, petugas tidak memihak dari kedua belah pihak yang bersengketa. Juga ditemukan kasusnya dimediasi, kemudian diajukan ke pengadilan oleh pihak yang bersengketa untuk mengetahui posisi hukumnya. Setelah mengetahui kemungkinan yang akan terjadi jika kasusnya diteruskan di pengadilan, para pihak akhirnya melakukan perdamaian di luar mediasi Kantah dan pengadilan, tetapi kesepakatan damainya dilaporkan ke Kantah.

Tipologi konflik pertanahan di Kabupaten Tangerang umumnya adalah mengenai penguasaan dan pemilikan tanah:

a. Sengketa lama yang berkembang menjadi konflik dan kasus masuk ke pengadilan, misalnya kasus badan hukum (Bumi Serpong Damai) versus perseorangan;

b. Tanah-tanah bekas Hak Barat (Belanda), biasanya yang mengaku ahli waris De Meyer;

c. Tanah Eks Pejuang 45.

d. Penguasaan dan pemilikan tanah.

Tabel 3. Beberapa Penanganan Sengketa, Konflik Kantor Pertanahan Di Kabupaten tangerang Tahun 2011

\begin{tabular}{|c|c|c|c|c|c|c|}
\hline No & Para Pihak & Pokok Masalah & $\begin{array}{c}\text { Jenis } \\
\text { Masalah }\end{array}$ & $\begin{array}{l}\text { Letak \& Luas } \\
\text { Tanah }\end{array}$ & $\begin{array}{c}\text { Upaya } \\
\text { Penyelesaia } \\
n\end{array}$ & Keterangan \\
\hline 1. & $\begin{array}{l}\text { Yohanes } \\
\text { Indrayono } \\
\text { vs Abdul } \\
\text { Kodir }\end{array}$ & $\begin{array}{l}\text { Tumpang Tindih } \\
\text { antara sertipikat HM } \\
\text { dengan sertipikat } \\
\text { HGB dalam satu } \\
\text { wilayah yang sama. }\end{array}$ & Sengketa & $\begin{array}{l}\text { Ds Kedaung Kec. } \\
\text { Pamulang } \\
\text { Luas : } 840 \mathrm{M} 2\end{array}$ & Mediasi & $\begin{array}{l}\text { Telah diundang mediasi } \\
\text { tetapi pihak Kantah dan } \\
\text { Yohanes (pelapor) } \\
\text { kesulitan mencari } \\
\text { alamat Abdul kodir, } \\
\text { sebab di cari di alamat } \\
\text { yg diwarkah tidak } \\
\text { diketemukan. }\end{array}$ \\
\hline 2. & Hadi Arsali & Sengketa & Sengketa & Pakulonan & Mediasi & Mediasi Lanjutan \\
\hline
\end{tabular}




\begin{tabular}{|c|c|c|c|c|c|c|}
\hline & $\begin{array}{l}\text { vs PT. Alfa } \\
\text { Goldland } \\
\text { Serpong } \\
\text { (Alam } \\
\text { Sutera) }\end{array}$ & $\begin{array}{l}\text { Penguasaan } \\
\text { kepemilikan antara } \\
\text { tanah adat dengan } \\
\text { HGB }\end{array}$ & & $\begin{array}{l}\text { Kec. } \quad \text { Serpong } \\
\text { Utara } \\
\text { Luas : } 2.670 \mathrm{M} 2\end{array}$ & & \\
\hline 3. & $\begin{array}{l}\text { Dadang } \\
\text { Abuhanifah } \\
\text { Zachri, BA } \\
\text { vs Ir. Ida } \\
\text { Bagus } \\
\text { Rajendra } \\
\text { Wesnawa }\end{array}$ & $\begin{array}{lr}\text { Penguasaan } & \text { dan } \\
\text { pemilikan } & \text { tanah } \\
\text { berdasarkan } & \\
\text { Girik/Letter } \text { C desa }\end{array}$ & Sengketa & $\begin{array}{l}\text { Ds. Pondok Karya } \\
\text { Kec. Pondok Aren } \\
\text { Luas : } 602 \text { M2 }\end{array}$ & Mediasi & $\begin{array}{l}\text { Pihak Pelapor } \\
\text { mengajukan gugatan ke } \\
\text { PTUN (selesai) }\end{array}$ \\
\hline 4. & $\begin{array}{l}\text { Ujang } \\
\text { Zulkarnaen } \\
\text { vs PT. Reni } \\
\text { Jaya }\end{array}$ & $\begin{array}{l}\text { Tumpang tindih } \\
\text { antara SHM No. } 272 \\
\text { dengan HGB a.n PT. } \\
\text { Reni Jaya }\end{array}$ & Sengketa & $\begin{array}{lr}\text { Kel. } & \text { Pondok } \\
\text { Benda } & \text { Kec. } \\
\text { Ciputat Kota } & \end{array}$ & Mediasi & $\begin{array}{l}\text { Dua mediasi terakhir } \\
\text { bulan maret tetapi tdk } \\
\text { ada kesepakatan } \\
\text { disarankan untuk ke } \\
\text { Pengadilan (selesai) }\end{array}$ \\
\hline
\end{tabular}

Kendala yang dihadapi Kantor Pertanahan dalam penyelesaian konflik pertanahan, antara lain:

a) Penyelesaian hanya dalam formal, meski kasus tidak selesai.

b) Suatu kasus bisa penanganannya selesai, tapi kasusnya tidak selesai.

c) Kesulitan mengikuti Petunjuk Teknis.

d) Volume pekerjaan yang tidak sesuai dengan jumlah staf.

e) Pihak pelapor sering tidak datang ketika diundang mediasi tanpa laporan alasan ketidakhadirannya.

\subsubsection{Provinsi Papua}

\subsubsection{Kota Jayapura}

Tiga hal mendasar yang menjadi pangkal timbulnya masalah tanah di Kota Jayapura khususnya dan Provinsi Papua pada umumnya adalah :

1. Adanya perbedaan persepsi hukum pertanahan antara masyarakat adat dengan hukum pertanahan nasional. Perbedaan tersebut dapat dipahami, karena hukum pertanahan nasional dibangun berlandaskan hukum ADAT MELAYU, sedangkan masyarakat adat sejak lahir dalam hidupnya dituntun dengan hukum adat MELANESIA sehingga sangat dimungkinkan adanya prinsip yang tidak singkron bahkan bertentangan. Walaupun belum ditemukan referensi yang menguraikan adanya perbedaan persepsi antara hukum adat Melayu dengan hukum adat Melanesia. Namun dalam kehidupan sehari-hari khususnya dalam pengelolaan masalah tanah dapat ditemui adanya perbedaan tersebut misalnya : 
a. Adanya anggapan bahwa Tanah adalah mama, artinya permasalahan tanah menyangkut masalah kehormatan keluarga sementara dalam hukum nasional tanah cenderung diartikan sebagai obyek atau komoditas.

b. Tanah dapat dialihkan kepada pihak lain, tetapi sebatas hak untuk memakai ( bukan untuk memiliki). Padahal dalam hukum Pertanahan Nasional, apabila sebidang tanah telah dialihkan kepada pihak lain maka hubungan hukum antara tanah dengan bekas pemiliknya menjadi putus.

\section{Batas Tanah Ulayat Tidak Jelas}

Pengakuan wilayah ulayat masih tradisional dan menjadikan batas alam sebagai batas tanah ulayatnya. Seperti : gunung, bukit, pohon besar dan sungai (tidak permanen). Pada saat tanah belum mempunyai nilai ekonomis atau masih rendah nilai ekonominya, tanah tersebut tidak menjadi masalah. Faktor kekerabatan memberi toleransi apabila pihak adat suku lain datang ke lokasi untuk sekedar berburu atau memetik hasil alam lainnya (meramu).

Masalahnya menjadi lain apabila tanah tersebut sudah mempunyai nilai ekonomis. Tanah dapat diperebutkan antara berbagai suku, dan untuk memperebutkan tanah tersebut tidak tertutup kemungkinan terjadinya pertikaian antara suku.

3. Struktur Pemilikan Tanah Tidak Jelas.

Tidak dapat dipastikan siapa yang mempunyai kewenangan untuk melakukan perbuatan hukum atas bidang tanah ulayat.

Ada pihak yang menyatakan bahwa yang berhak melakukan perbuatan hukum atas tanah adat / ulayat adalah ONDOAFI tetapi ada pihak yang menentangnya dengan argumentasi bahwa ondoafi hanya berfungsi sebagai pengayom, pelindung, dan mengkoordinasikan beberapa kepala suku, sedangkan yang mempunyai kewenangan operasional termasuk melakukan perbuatan hukum atas tanah adalah KEPALA SUKU.

Saat ini timbul fenomena baru, yaitu adanya beberapa pihak yang mengupayakan agar setiap pembayaran ganti rugi tanah memberi perhitungan tersendiri bahkan ada yang menuntut agar pemberian ganti rugi dibayarkan kepada MATA RUMAH karena merekalah yang menguasai, menggarap dan memanfaatkan tanah itu.

Tidak Ada Tanah Yang Tidak Bertuan kalimat tersebut merupakan prinsip yang dipegang kuat oleh masyarakat adat walaupun suatu kawasan belum pernah dijamah oleh seseorang atau sekelompok orang, namun seluruh tanah di Provinsi Papua adalah tanah adat / ulayat

Menurut Undang Undang No. 41 Tahun 1999 menyatakan bahwa kawasan hutan adalah tanah negara, namun kenyataannya apabila ada kegiatan yang menggunakan tanah (sekalipun kawasan hutan lindung) harus memberikan ganti rugi kepada masyarakat yang mengaku sebagai pemiliknya. Kondisi sebagaimana dimaksud di atas menimbulkan berbagai permasalahan yang dapat mengganggu kegiatan pembangunan, pemerintahan dan kemasyarakataan. Okupasi liar, pemalangan lokasi, tuntutan ganti rugi aset pemerintah, penjualan berulang dan lain-lain sering ditemui di Kota Jayapura Provinsi Papua. 
Ada beberapa jenis konflik yang terjadi di wilayah ini, yaitu :

1. Okupasi Liar

Suatu kawasan tertentu yang telah dilepaskan hak atas tanahnya, apabila dalam kurun waktu tertentu belum dimanfaatkan dapat dikuasai kembali baik oleh pihak yang telah melepaskan maupun pihak lain yang diberi kewenangan oleh pihak yang telah menjual. Bahkan ada yang menjual kembali tanah yang pernah dijualnya

2. Pemalangan Lokasi.

Bidang tanah yang pernah dijual oleh orang tuanya sering dituntut ganti rugi tanahnya oleh keturunanya. Apabila tidak dipenuhi tuntutan ganti rugi dimaksud mereka dapat melakukan pemalangan lokasi dengan pengerahan massa sebagai upaya pemaksaan kehendak.

3. Tuntutan Ganti Rugi Aset Pemerintah

Banyak aset Pemerintah (termasuk lokasi Kantor Pertanahan Kota Jayapura) yang telah didaftarkan (bersertipikat) dan dikuasai serta digunakan secara terus menerus dimana pendaftaran dan penguasaan tersebut didasari dengan OVEREENSCOMST 1956 tetapi dituntut ganti rugi tanahnya oleh masyarakat adat dengan alasan belum ada pembayaran kepada mereka. Ironisnya untuk menyelesaikan tuntutan tersebut tidak mau mengajukan gugatan melalui lembaga peradilan. Mereka lebih suka menempuh cara penekanan dan pemaksaan kehendak sebagaimana diuraikan pada angka 2 di atas.

4. Penjualan Berulang

Ketidakjelasan batas wilayah mengakibatkan tidak jelasnya pemilikan bidang tanah tertentu. Dapat saja terjadi satu bidang tanah diaku sebagai milik oleh beberapa suku tertentu. Akibatnya bidang tanah tersebut apabila telah dijual kepada pihak lain sering terjadi suku yang lain menjual tanah yang sama kepada pihak yang berbeda

Pemahaman terhadap istilah Turun Temurun.

Ada sementara masyarakat yang mempunyai pemahaman berbeda dengan pemahaman masyarakat yang lazim dianut oleh masyarakat Indonesia. Terkait dengan hak turun temurun terhadap tanah, menurut mereka tidak ada batas waktu untuk menikmati hasil dari tanah itu .

5. Tanah yang telah dijual oleh orang tua kemudian diolah / digarap oleh pembeli, karena yang mereka itu hanya mempunyai hak untuk memakai maka turunan dari penjual sampai tingkatan yang tidak terbatas dianggap mempunyai hak menikmati hasil dari tanah tersebut.

Kondisi sebagaimana diuraikan di atas dapat terjadi secara terpisah dan dapat pula terjadi bersamaan. Tanpa pemahaman yang tepat dan mendalam terhadap persepsi tersebut, maka kita akan mengatakan bahwa perbuatan itu tidak benar, bertentangan dengan aturan, melanggar hukum dan berbagai istilah lain yang menyatakan perbuatan tersebut sifatnya negatif. Namun kita akan berkata lain apabila kita mempunyai referensi yang cukup terhadap masalah tersebut. ${ }^{10}$

10 Andriatmo, kepala Bidang Pemberdayaan Kantor Wilayah BPN Provinsi Papua, 2011. 


\subsubsection{Kabupaten Jayapura}

Konflik yang terjadi di Kabupaten Jayapura tidak sebanyak jumlahnya dengan Kota Jayapura, relatif sedikit. Ada beberapa kasus yang agak besar yakni masalah Bandara Udara Sentani dimana masyarakat adat menuntut bahwa bagian dari bandara yakni runway merupakan tanah masyarakat adat dari suatu suku disana. Sudah terjadi penggantian dari Pemerintah Daerah hanya saja belum lama ini ada dari suku adat lainpun yang mengklaim bahwa daerah bandara merupakan tanah masyarakat adat suku tersebut. Hal inilah yang menjadi permasalahan tidak selesai selesai karena apabila telah terjadi kesepakatan untuk penggantian maka nantinya ada masyarakat adat suku lainnya yang akan menuntut tanah yang disengketakan tadi.

\subsubsection{Provinsi Bali}

Konflik yang terjadi di Provinsi Bali kebanyakan berasal dari masyarakat adat, dimana sejak adanya desa adat yang diberdayakan sejak terbitnya Undang-Undang Otonomi Daerah terbagi atas dua yaitu :

1. Desa Dinas (Pemerintahan)

2. Desa Adat yang mengurusi adat-istiadat dan membawahi empat atau lebih Desa Dinas

Bentuk/tipe masalah yang banyak ditemukan di wilayah ini adalah masalah penguasaan dan pemilikan tanah.

Para pihak yang terkait dalam konflik ini adalah :

1. Desa adat versus desa adat

2. Desa adat versus badan hukum

3. Desa adat versus pemda provinsi

4. Desa adat versus masyarakat adat

\subsubsection{Kabupaten Buleleng}

Konflik yang ditemukan di di Buleleng antara lain :

\section{Kasus Sumber Kelampok}

Merupakan konflik yang sudah lama terjadi kabupaten Buleleng yaitu adanya tanah HGU yang telah habis masa berlakunya, namun belum diajukan permohonan perpanjangan hak, karena terjadi perebutan penguasaan tanah tersebut antara Pemerintah Provinsi Bali, Pemerintah Kabupaten Buleleng, perusahaan/badan hukum dan masyarakat sekitar.

Dikenal sebagai HGU Nomor 1/Desa Sumberklampok atas nama PT Darma Jati dan HGU Nomor 2 dan 3/Desa Sumberklampok atas nama PT Margarana. Kondisi fisik dilapangan tanah perkebunan tersebut dipergunakan untuk perumahan yang ditata dengan baik dan dekat dengan jalan raya, dari tahun 1992 pihak perkebunan tidak pernah menerima hasil karena sebagian besar kelapa tidak berbuah 
Kemudian HGU Nomor 1/Desa Pemuteran seluas 246,5000 ha tidak diperpanjang oleh PT Margarana karena adanya surat Bupati kepada Kepala Kantor Pertanahan tanggal 5 Agustus 2003 yang isinya meminta Kepala Kantor Pertanahan Buleleng untuk tidak menyetujui permohonan perpanjangan HGU yang dikuasai oleh PT Margarana, hal ini beralasan karena ditinjau dari segi produktivitas hasil tanaman kelapa dan kapuk kurang berhasil karena dari 9.233 pohon kelapa hanya menghasilkan kelapa sebanyak 111.069 butir per tahun dan kapuk hanya menghasilkan 12 ton per tahun, kemudian lokasi perkebunan tersebut sesuai dengan Rencana Umum Tata Ruang Wilayah tersebut ditetapkan sebagai kawasan wisata. Kondisi fisik dilapangan tanah perkebunan tersebut sebagian sudah dikuasai oleh masyarakat baik eks pekerja perkebunan maupun masyarakat disekitar lokasi secara liar. Dari sisi pemanfaatannya untuk perkebunan kelapa dan kapuk yang sesuai hanya seluas 61,63 ha atau $25 \%$ sedangkan pemanfaatan yang tidak sesuai seluas 187,87 ha atau $75 \%$ meliputi pemukiman dan areal pertanian rakyat.

\section{Kasus Desa Lemukih}

Konflik terjadi antara masyarakat dengan Pemegang sertipikat yang berakhir dengan bentrokan terjadi di Desa Adat Lemukih Kecamatan Sawan Kabupaten Buleleng yang pada akhirnya dilakukan rapat koordinasi yang diketuai oleh Gubernur Bali dengan mengundang beberapa pihak yang terkait diantaranya adalah :

- Ketua Komisi I DPRD Prov. Bali

- Kapolda Bali

- Bupati Buleleng

- Kapolres Buleleng

- Tim Investigasi masalah Lemukih

- Asisten Pemerintahan Sekda Prov. Bali

- Ka Kanwil BPN Prov. Bali

- Kepala Badan Kesbangpol dan Linmas Prov. Bali

- Kepala Biro Pemerintahan Setda Prov. Bali

- Kepala Biro Ekonomi dan Pembangunan Setda Prov. Bali

- Kepala Biro Humas dan Protokol Setda Prov. Bali

- Kepala Badan Kesbangpol dan Linmas Kab. Buleleng

- Kepala Kantor Pertanahan Kab. Buleleng

- Camat Sawan Kab. Buleleng

- Kepala Desa Lemukih, Kecamatan Sawan Kab. Buleleng

- Bendesa Pekraman Lemukih Kec. Sawan Kab. Buleleng

Berdasarkan data-data dari Kantor Pertanahan Kabupaten Buleleng tentang masalah sengketa tanah Desa Adat Lemukih sebagai berikut : 
1. Bahwa untuk tanah-tanah laba Pura dikarenakan pura sudah ditunjuk sebagai badan hukum keagamaan yang dapat mempunyai hak milik atas tanah sesuai dengan SK Kemendagri tgl 24 September 1986 No. SK.556/DJA/1986, maka terhadap tanah-tanah milik Pura baik untuk tegak Pura maupun pelaba Pura dalam pensertipikatannya ditempuh melalui jalur konversi.

2. Bahwa untuk proses penerbitan sertipikat yang bermasalah dimaksud ditempuh melalui penyalinan penegasan hak (konversi tidak langsung) yang seharusnya terlebih dahulu dilakukan peralihan hak dari tanah Druwe Pura kepada perorangan dibuktikan dengan kuitansi jual beli/hibah/tukar/menukar, yang ternyata dalam berkas penerbitan surat keputusannya tidak diketemukan bukti-bukti tersebut.

3. Dengan tidak adanya bukti peralihan hak, sehingga mengakibatkan cacat administrasi dalam prosedur penerbitan SK Gubernur yang menjadi dasar penerbitan sertipikat dimaksud.

Dari substansi permasalahan tersebut dapat disimpulkan sebagai berikut :

Status tanah tersebut adalah tanah Druwe Pura yang dalam prosedur penerbitan sertipikat atas nama perorangan tidak dibuktikan adanya peralihan hak sehingga terdapat cacat administrasi dalam penerbitan sertipikatnya.

> Dalam sertipikat yang dikeluarkan oleh Kantor Pertanahan Kabupaten Buleleng tidak mencantumkan letak dan batas tanah, oleh karenanya BPN pada tanggal 27 Agustus 2009 merencanakan melakukan pengukuran namun suasana sudah tidak kondusif dikarenakan warga pemegang sertipikat melakukan protes bahkan cenderung mengarah ke tindak kriminal sehingga petugas merasa tidak bisa melaksanakan tugasnya karena jiwanya terancam selanjutnya kegiatan pengukuran tersebut tidak bisa dilanjutkan. Pasca pembatalan pengukuran terjadi berbagai kasus hukum di Desa Lemukih mulai dari perusakan sampai pada pembakaran rumah dan penganiayaan warga.

> Komisi I DPRD dalam kasus ini mengharapkan agar dapat diselesaikan secara musyawarah dan mufakat namun apabila berlanjut dan berujung konflik, maka mengajak Pemerintah Kabupaten Buleleng untuk berani mengungkap pihak-pihak yang bermain dalam memperkeruh suasana, dan meminta agar segera diambil tindakan sesuai dengan ketentuan dan hukum yang berlaku.

\subsubsection{Kabupaten Karang Asem}

Adanya Pemunder (wasiat) Desa Adat Culik yang isinya diyakini sebagai alat bukti kepemilikan terhadap tanah-tanah yang ada di wilayah Desa Adat Culik termasuk didalamnya tanah yang dikuasai oleh Dadia I Gede Badung. Bertitik tolak dari wasiat tersebut telah diambil tindakan pemasangan papan nama di atas tanah milik adat yang dikuasai oleh Dadia I Gede Badung oleh warga Desa Adat Culik. Dengan adanya pemasangan papan nama maka pihak Dadia I Gede Badung berdasarkan surat pengurus Dadia I Gede Badung tanggal 5 Nopember 2000 Nomor 06/DIGB/KEB/2000 memohon perlindungan hukum kepada pemerintah Kabupaten Karang Asem. Kemudian terhadap permohonan perlindungan hukum tersebut telah diadakan 
pembahasan dengan pihak instansi terkait termasuk Kantah Kabupaten Karang Asem dengan hasil :

- Secara yuridis formal tanah-tanah yang diterbitkan sertipikat-sertipikat atas nama Pura Dadia I Gede Badung, dikuasai/dimiliki turun temurun sejak tahun 1924 berdasarkan "Keputusan De Raad Van Kertha'S" dan sesuai pula dengan surat berupa Petuk D, diperkuat lagi dengan Surat Keterangan dari Kepala Kantor Iuran Pembangunan Daerah Bali Selatan tanggal 15 Juli 1970 No.189 dan No. 190 tahun 1970, putusan Pengadilan Negeri Amlapura Nomor 25/Pdt/K.A/1970 tanggal 19 November 1970, putusan Pengadilan Tinggi Denpasar Nomor 128/PTD/1970/Pdt tanggal 14 Februari 1972 dan Putusan Mahkamah Agung Republik Indonesia Nomor 774.K/Sip/1972 tanggal 14 Januari 1976 dalam perkara perdata antar Dadia I Gede Badung sebagai tergugat dan Desa Adat Culik sebagai penggugat yang telah mempunyai kekuatan hukum tetap.

- Bahwa dengan telah diterbitkan sertipikat-sertipikat hak milik tersebut di atas, pihak Desa Adat Culik tetap mengklaim bahwa tanah tersebut merupakan milik Pura Puseh Desa Adat Culik dengan bukti pemilikan berupan Pemunder (wasiat dari Raja Karang Asem) dan lebih lanjut pihak Desa Adat Culik bersama warganya datang ke Kantah Kabupaten Karang Asem meminta agar sertipikatsertipikat tersebut dibatalkan.

- Posisi permasalahan tersebut saat ini sebagai berikut :

- Atas dasar Putusan Pengadilan Tata Usaha Negara Nomor 13/G/2001/PTUN Denpasar tanggal 14 Nopember 2001 (Kantah Kabupaten Karang Asem selaku pihak yang dikalahkan telah melakukan upaya hukum banding).

- Atas dasar Putusan Pengadilan Tinggi Tata Usaha Negara Surabaya Nomor 34/B/TUN/2002/PTTUN tanggal 14 Maret 2002 Kantah Kabupaten Karang Asem selaku pihak yang dikalahkan, oleh karenanya telah mengajukan upaya hukum kasasi kepada Mahkamah Agung RI, karena Kantah Kabupaten Karang Asem tidak pernah mengirim memori banding yang disebabkan adanya penekanan-penekanan yang dilakukan oleh Desa Adat Culik yang berakibat Kantah Kabupaten Karang Asem dirusak, dan sebagian peralatan dan berkas-berkas pelayanan dibakar oleh pihak Desa Adat Culik.

- Secara fisik tanah tersebut tetap digarap oleh penggarap Dadia I Gede Badung dan menurut informasi dari Desa Adat Culik ada beberapa bidang tanah dimaksud hasilnya oleh para penggarap diberikan kepada Desa Adat Culik.

- Masalah terakhir pihak Dadia I Gede Badung dikeluarkan (dipecat) dari Desa Adat Culik, sebagai akibat dari dikeluarkannya dari Desa Adat Culik pihak Dadia I Gede Badung ingin membentuk Desa Adat tersendiri, namun dalam rangka untuk meresmikan pembentukan Desa Adat yang baru bernama Desa Adat Kebon Dungus tersebut terjadi kerusuhan (pembakaran rumah penduduk warga Dadia I Gede Badung dan menimbulkan korban jiwa satu orang, tanggal 4 Juni 2002).

\section{Tabel 4. Studi Kasus Desa Culik}

\begin{tabular}{|c|c|c|}
\hline Pokok Masalah & Identifikasi Masalah & Penyelesaian Masalah \\
\hline 1 & 2 & 3 \\
\hline Terbitnya Sertipikat & 1. Desa Adat Culik menemukan & 1.a. Dilaporkan ke Kanwil BPN \\
\hline
\end{tabular}




\begin{tabular}{|c|c|c|}
\hline $\begin{array}{l}\text { atas nama Pura Dadia } \\
\text { I Gede Badung }\end{array}$ & $\begin{array}{l}\text { data di Kantor Pertanahan } \\
\text { 2. Mohon ijin untuk mendapatkan } \\
\text { data ke Kantah Kab. Kr. Asem } \\
\text { 3. Disetujui denga Surat Kakanwil } \\
\text { BPN tanggal 26 April 2001 } \\
\text { Nomor 630.1.61-455 } \\
\text { 4. Desa adat mengajukan } \\
\text { pendaftaran gugatan PTUN } \\
\text { Denpasar Nomor Perkara 29 } \\
\text { Mei, REG No. } \\
\text { 13/6/2001/PTUN.DPS } \\
\text { 5eputusan PTUN Denpasar tgl } \\
\text { 5 Nopember 2001 isinya BPN } \\
\text { dikalahkan } \\
\text { 6erdasar point 5 Desa Adat } \\
\text { Culik (Penggugat) mohon agar } \\
\text { BPN tergugat tidak banding } \\
\text { dengan surat tgl } 9 \text { Nopember } \\
\text { 2001 No. 81/DAK/PL/2001 } \\
\text { 7. Diteruskan ke Kanwil BPN } \\
\text { dengan surat tgl 22 Nopember } \\
\text { 2001 No. 570.1-1812-KRS. } \\
\text { 8. Kanwil BPN Provinsi Bali } \\
\text { meneruskan ke BPN Pusat tgl 23 } \\
\text { Nopember 2001 No. R.570.61- } \\
\text { 1195. } \\
\text { 9. Surat dari BPN Pusat tgl 27 } \\
\text { Nopember 2001 N0. } \\
\text { X.570.81.3351-DI.2 isinya harus } \\
\text { dilakukan hukum banding } \\
\text { 10. Desa Adat Culik menyampaikan } \\
\text { pernyataan sikap di DPRD Kab. } \\
\text { Kr. Asem tgl 24 Desember 2001 } \\
\text { 11. Tanggal 26 Desember 2001 di } \\
\text { rapatkan Pemda dan Muspida. } \\
\text { Keputusan tidak ada karena } \\
\text { peserta meninggalkan tempat } \\
\text { Akan menggunakan cara sendiri } \\
\text { 12. Tanggal 28 Desember 2001 } \\
\text { terjadi pengrusakan dan } \\
\text { pembakaran Kantor Pertanahan }\end{array}$ & $\begin{array}{l}\text { Provinsi Bali tgl } 28 \\
\text { Desember 2001 via } \\
\text { telepon } \\
\text { b. Sekitar jam 11 WITA } \\
\text { Bapak Kakanwil datang ke } \\
\text { Kr. Asem langsung } \\
\text { mengadakan pertemuan } \\
\text { dengan Muspida Kab. Kr. } \\
\text { Asem. } \\
\text { Hasil Rapat: } \\
\text { Perlu adanya Kamtibmas } \\
\text { di Kab. Kr. Asem } \\
\text { c. Bupati Kr. Asem di ketahui } \\
\text { ketua DPR menyarankan } \\
\text { mencabut upaya banding } \\
\text { dengan surat tgl 28 } \\
\text { Desember 2001 No. } \\
\text { 180/5060/HK } \\
\text { Upaya banding dari } \\
\text { Kantah Pertanahan Kab. } \\
\text { Kr. Asem tetap } \\
\text { dilaksanakan dengan surat } \\
\text { tgl. 26 Nopember 2001 } \\
\text { No. 570.61-1819-KRS. } \\
\text { Dengan putusan PTUN } \\
\text { Surabaya No. } \\
\text { 34/B/TUN/2001/PT.TUN.SB } \\
\text { Y tgl 14 Maret 2002 } \\
\text { menguatkan putusan PTUN } \\
\text { Denpasar. } \\
\text { 3. Kantah mengajukan } \\
\text { permohonan kasasi dan } \\
\text { diterima PT.TUN Denpasar } \\
\text { tgl. 20 Mei 2002 } \\
\text { 4. Belum ada putusan } \\
\text { sampai saat ini. }\end{array}$ \\
\hline
\end{tabular}

\subsection{Para Pihak Dalam Penanganan Konflik}

PP No. 38 tahun 2007 tentang Pembagian Urusan Pemerintahan Antara Pemerintah, Pemerintahan Daerah Provinsi, dan Pemerintahan Daerah Kota/Kabupaten dinyatakan bahwa kewenangan Pemerintah di bidang pertanahan dilaksanakan oleh Pemerintah Kabupaten/Kota.Kewenangan sebagaimana dimaksud adalah : 
a. pemberian ijin lokasi;

b. penyelenggaraan pengadaan tanah untuk kepentingan pembangunan;

c. penyelesaian sengketa tanah garapan;

d. penyelesaian masalah ganti kerugian dan santunan tanah untuk pembangunan;

e. penetapan subyek dan obyek redistribusi tanah, serta ganti kerugian tanah kelebihan maksimum dan tanah absentee;

f. penetapan dan penyelesaian masalah tanah ulayat;

g. pemanfaatan dan penyelesaian masalah tanah kosong;

h. pemberian ijin membuka tanah;

i. perencanaan penggunaan tanah wilayah Kabupaten/Kota.

Berdasarkan kewenangan tersebut di atas, maka Pemerintah Daerah membentuk Tim Penyelesaian Sengketa dan Konflik Pertanahan.

\subsubsection{Provinsi Jambi}

Adanya SK Gubernur No. 96/Kep.Gub/Ekbang-SDA/2011 tentang Pembentukan Tim Inventarisasi, Pengkajian dan Mediasi Konflik Lahan di Provinsi Jambi. Tim sengketa terdiri dari 1)Tim Koordinasi, dengan susunan personalia antara lain Gubernur Jambi, Wakil Gubernur Jambi, Ketua DPRD Jambi, Kapolda Jambi, Ketua Pengadilan Tinggi Jambi, Kepala Kejaksaan Tinggi Jambi, Ketua Komisi II DPRD Jambi sebagai Pengarah, 2) Pokja Inventarisasi dan Pengkajian,3) Pokja Fasilitasi dan Mediasi, 4) Sekretariat. Tugas dari Tim Sengketa antara lain, 1)melakukan koordinasi dengan seluruh komponen stakeholder dalam rangka penyelesaian konflik, 2) melakukan inventarisasi dan pengkajian konflik lahan yang terjadi di Provinsi Jambi, 3) memetakan konflik sesuai dengan kewenangan dan memeberikan rekomendasi kepada daerah Provinsi /Kabupaten/Kota untuk menyelesaikan konflik sesuai dengan kewenangannya, 4)melakukan fasilitasi dan mediasi dalam rangka penyelesaian konflik, 5) memberikan pendapat, saran dan pertimbangan hukum terkait dengan konflik lahan baik kepada Pemerintah, pengusaha ataupun kepada masyarakat, 6) melaporkan hasil kerjanya kepada Gubernur.

Sebelum dibentuk Tim di atas, pembentukan Tim Sengketa bersifat temporer dengan memperhatikan dampak dari kasus yang ada.

\subsubsection{Provinsi Sulawesi Utara}

Belum ada Tim Sengketa khusus yang menangani konflik pertanahan.

\subsubsection{Provinsi Banten}

Belum ada Tim Sengketa khusus yang menangani konflik pertanahan

\subsubsection{Provinsi Papua}


Papua juga sudah mengeluarkan Keputusan Gubernur No. 189 tahun 2009 tentang Pembentukan Tim terpadu Penyelesaian Masalah-masalah Pertanahan di Provinsi Papua. Tugas dari Tim ini adalah 1) mengidentifikasi masalah-masalah pertanahan di Provinsi Papua, 2) membahas dan mengkaji masalah-masalah pertanahan di Provinsi Papua, 3) memberikan saran pertimbangan kepada Gubernur Provinsi Papua untuk penyelesaian masalah pertanahan di Provinsi Papua. Yang termasuk sebagai Dewan Pembina Tim yaitu Gubernur, Wakil Gubernur, Ketua DPR Papua, dan Ketua Majelis Rakyat Papua.

\subsubsection{Provinsi Bali}

Belum ada Tim Sengketa khusus yang menangani konflik pertanahan

\subsection{Upaya penanganan konflik}

\subsubsection{Provinsi Jambi}

Dari berbagai permasalahan tersebut di atas, telah dilakukan upaya mediasi bagi para pihak yang terkait. Di bawah ini tabel mediasi yang sudah dilaksanakan di Provinsi Jambi.

Tabel 5. Mediasi Konflik Pertanahan di Provinsi Jambi

\begin{tabular}{|c|c|c|c|}
\hline No & Tipologi Masalah & Akar Masalah & Penyelesaian \\
\hline 1. & $\begin{array}{l}\text { Penguasaan dan } \\
\text { pemilikan tanah }\end{array}$ & $\begin{array}{l}\text { Pengaduan masyarakat Desa Tanjung } \\
\text { Lanjut yang memohon pengembalian } \\
\text { lahan Perkebunan Kelapa Sawit } \\
\text { seluas } 2.100 \text { ha yang dikuasai PT. } \\
\text { Kirana Sekernan sejak tahun } 2001 . \\
\text { Lahan yang dipermasalahkan dalam } \\
\text { bentuk HGU PT. Kirana Sekernan }\end{array}$ & $\begin{array}{l}\text { Hasil mediasi tanggal } 25 \text { Oktober } \\
2010 \text { akan dilakukan identifikasi } \\
\text { melalui citra satelit dan ground } \\
\text { truth terhadap batas HGU } \\
\text { maupun inventarisasi penguasaan } \\
\text { dan pemilikan tanah masyarakat } \\
\text { yang dienclave dalam HGU }\end{array}$ \\
\hline 2. & $\begin{array}{l}\text { Penguasaan dan } \\
\text { pemilikan tanah }\end{array}$ & $\begin{array}{l}\text { Luas areal yang diserahkan oleh } \\
\text { Kelompok Tani Berkah Abadi kepada } \\
\text { PT Kirana Sekernan selaku Avalis } \\
\text { Kelompok Tani Seruni diduga } \\
\text { melebihi dari luas yang diperjanjikan } \\
\text { seluas } 648,35 \text { ha }\end{array}$ & $\begin{array}{l}\text { Telah dimediasi } \text { dengan } \\
\text { kesepakatan akan dilakukan } \\
\text { pengukuran kembali atas biaya } \\
\text { Kelompok Tani Berkah Abadi. } \\
\text { Pelaksanaan pengukuran tidak } \\
\text { ditindaklanjuti karena biaya } \\
\text { pengukuran yang sebelumnya } \\
\text { telah disetorkan oleh Kelompok } \\
\text { Tani Berkah Abadi ditarik } \\
\text { kembali disebabkan pada saat } \\
\text { survei pendahuluan areal yang } \\
\text { dipermasalahkan tidak dapat } \\
\text { diidentifikasi dengan tegas letak } \\
\text { dan batas tanah dimaksud. } \\
\text { Dengan demikian permasalahan } \\
\text { tersebut tidak dapat dimediasikan } \\
\text { lebih lanjut sehingga disarankan }\end{array}$ \\
\hline
\end{tabular}




\begin{tabular}{|c|c|c|c|}
\hline & & & $\begin{array}{l}\text { penyelesaiannya melalui jalur } \\
\text { hukum }\end{array}$ \\
\hline 3. & $\begin{array}{l}\text { Penguasaan dan } \\
\text { pemilikan tanah }\end{array}$ & $\begin{array}{l}\text { Pemberian kebun plasma dari PTPN } \\
\text { VI kabupaten Muaro Jambi kepada } \\
235 \text { KK yang berada di lahan HGU } \\
\text { PT. Asiatic Persada. Tanah yang } \\
\text { dipermasalahkan adalah HGU PT. } \\
\text { Asiatic Persada }\end{array}$ & 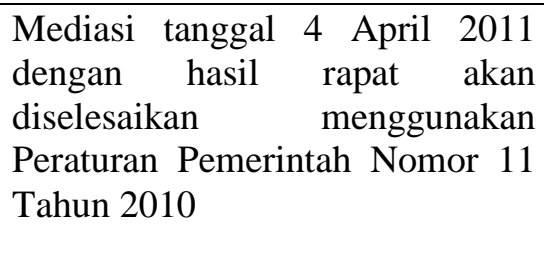 \\
\hline 4. & $\begin{array}{l}\text { Penguasaan dan } \\
\text { pemilikan tanah }\end{array}$ & $\begin{array}{l}\text { Pembagian Kebun Plasma untuk Suku } \\
\text { Anak Dalam. }\end{array}$ & $\begin{array}{l}\text { Hasil mediasi } \\
\text { Pemkab/Pemprov, telah ada } \\
\text { kesepakatan tahun } 2009 \text { bahwa } \\
\text { pihak perusahaan menyerahkan } \\
\text { areal kebun kelapa sawit seluas } \\
1.000 \text { ha kepada Suku Anak } \\
\text { Dalam di Kabupaten Batanghari }\end{array}$ \\
\hline 5. & $\begin{array}{lr}\text { Penguasaan } & \text { dan } \\
\text { pemilikan tanah. } & \text { Batas dan letak } \\
\text { bidang tanah } & \end{array}$ & $\begin{array}{l}\text { Sering berubahnya daftar kelompok } \\
\text { tani/anggota kelompok tani; Sebagian } \\
\text { areal masuk ke dalam kawasan hutan }\end{array}$ & $\begin{array}{l}\text { Hasil mediasi oleh Pemkab } \\
\text { Tangjung Jabung Timur tanggal } \\
23 \text { Agustus 2006 telah ada } \\
\text { kesepakatan damai bahwa PT } \\
\text { Bukit Barisan Indah Prima akan } \\
\text { menyerahkan sebagian areal } \\
\text { kebun kelapa sawit seluas 151 ha } \\
\text { kepada Kelompok Tani Batu } \\
\text { Awang/Batu Ampar. }\end{array}$ \\
\hline 6. & $\begin{array}{l}\text { Penguasaan dan } \\
\text { pemilikan tanah }\end{array}$ & $\begin{array}{l}\text { Dalam pembangunan kebun } \\
\text { kemitraan Suku Anak Dalam Sialang } \\
\text { Pungguk, bahwa, bahwa dari } 53 \mathrm{KK} \\
\text { Suku Anak Dalam Sialang Pungguk } \\
\text { berhak mendapat kebun plasma. } \\
\text { Tanah yang dipermasalahkan adalah } \\
\text { kebun kemitraan PT. Indo Kebun } \\
\text { Unggul berdasarkan Ijin Lokasi } \\
\text { seluas 12.898 ha yang berlokasi di } \\
\text { kecamatan Muara Bulian kabupaten } \\
\text { Batanghari }\end{array}$ & $\begin{array}{l}\text { Telah ada kesepakatan damai } \\
\text { melalui musyawarah pada tanggal } \\
12 \text { April } 2007 \text { bahwa pihak } \\
\text { perusahaan akan menyerahkan } \\
\text { kebun plasma di wilayah Muara } \\
\text { Singoan kecamatan Muara Bulian } \\
\text { kepada } 40 \text { KK Suku Anak Dalam }\end{array}$ \\
\hline 7. & $\begin{array}{l}\text { Penguasaan dan } \\
\text { pemilikan tanah }\end{array}$ & $\begin{array}{l}\text { Permohonan pencabutan HGU PT. } \\
\text { Jambi Agro Wijaya oleh } 7 \text { desa di } \\
\text { kecamatan Rauh kabupaten } \\
\text { Sarolangun karena ditelantarkan/tidak } \\
\text { ditanami oleh pemegang hak }\end{array}$ & $\begin{array}{l}\text { Sedang dimediasi oleh Pemkab } \\
\text { Sarolangun }\end{array}$ \\
\hline 8. & $\begin{array}{l}\text { Penguasaan dan } \\
\text { pemilikan tanah }\end{array}$ & $\begin{array}{l}\text { Konflik pertanahan antara PT. Sari } \\
\text { Aditya Loka (SAL) dengan } \\
\text { masyarakat desa Aburan Seberang } \\
\text { kecamatan Tebo Tengah kabupaten } \\
\text { Tebo }\end{array}$ & $\begin{array}{l}\text { Karena tidak ada kata sepakat, } \\
\text { maka penyelesaiannya melalui } \\
\text { jalur hukum }\end{array}$ \\
\hline 9. & $\begin{array}{l}\text { Penguasaan dan } \\
\text { pemilikan tanah }\end{array}$ & $\begin{array}{l}\text { Tanah seluas } 7.000 \text { ha di desa } \\
\text { Pangkal Duri kecamatan Mendahara } \\
\text { kabupatan Tanjung Jabung Timur, } \\
\text { yang dimana tanah tersebut oleh } \\
\text { masyarakat dianggap miliknya }\end{array}$ & $\begin{array}{l}\text { Pada tanggal } 8 \text { Juni } 2010 \text { telah } \\
\text { dibahas di tingkat provinsi } \\
\text { mendengarkan paparan data hasil } \\
\text { peninjauan lapangan oleh Tim } \\
\text { Verivikasi Provinsi Jambi }\end{array}$ \\
\hline
\end{tabular}




\begin{tabular}{|l|l|l|}
\hline & $\begin{array}{l}\text { berdasarkan Surat Keterangan Tanah, } \\
\text { tetapi PT. Wira Karya Sakti (WKS) } \\
\text { melalui pola kemitraan yang belum } \\
\text { terealisasi menggusur tanaman dan } \\
\text { gubuk masyarakat }\end{array}$ \\
\hline
\end{tabular}

Di Muaro Jambi, dalam konflik pertanahan, masyarakat tidak mengadu ke BPN, tetapi ke Pemkab. Di Pemkab mulai tahun 2005 dibentuk Tim Sengketa yang dipimpin oleh Asisten Dua, keanggotaanya juga melibatkan unsur dari kejaksaan dan kepolisian, Kantor Pertanahan masuk juga sebagai anggota sekaligus Tim Teknis. Tim ini melandaskan dirinya pada Peraturan Pemerintah Nomor 38 Tahun 2007 tentang Pembagian Urusan Pemerintahan Antara Pemerintah dengan Pemerintah Daerah Provinsi dan Pemerintah Daerah Kabupaten/Kota.

Fungsi Tim Sengketa adalah melakukan mediasi konflik pertanahan di berbagai tingkatan, mulai dari desa, kecamatan, kabupaten dan provinsi. Jika ada sengketa, tim langsung terjun ke lokasi. Konfliknya biasanya sengketa batas dan sengketa musiman saat panen durian dan duku. Batas desa belum ada yang pasti, akan timbul masalah apabila ada investasi yang masuk.

Kebijakan mediasi ini didukung oleh kultur masyarakat yang takut menggeser batas tanah dan masih kentalnya kekerabatan juga koordinasi antar intansi yang baik. Kesulitan memediasi justru pada pendatang yang memandang tanah dari segi komersil yang tinggi dan apabila melibatkan pengacara. Berita Acara Mediasi tidak dipublikasikan, untuk menghindari dicari-cari celah hukumnya.

Menurut Bapak Hasmi Hanafi, ${ }^{11}$ Kepala Kantor Pertanahan Batanghari, di era otonomi daerah, seharusnya ada koordinasi lintas instansi dalam upaya penyelesaian konflik pertanahan. Sebagai contoh di kabupaten Batanghari, lewat Surat Keputusan Bupati tentang tim terpadu untuk Suku Anak Dalam.

PT Asiatik Persada memiliki HGU sebesar 20.000 ha yang di dalamnya tinggal Suku Anak Dalam. 1. 000 ha dimitrakan dengan Suku Anak Dalam yang diatur melalui Peraturan Gubernur. Kemitraan ini dimanajemen lewat "Koperasi Sangat Mandiri" yang dibina oleh Pemda dalam hal ini Dinas Koperasi. Untuk supaya tepat sasaran, masyarakat yang mengaku Suku Anak Dalam diseleksi keasliannya dengan melihat keturunan dan sejarah oleh tetua-tetua adat Suku Anak Dalam.

Menurut Ibu Sri Noviyana, Kepala Seksi Konflik Pertanahan Kantor Pertanahan Batanghari, kendala dari mediasi adalah Perusahaan sering ingkar janji dan sumber daya manusia di Kantor Pertanahan Batanghari belum sesuai dengan progam.

Di kabupaten Batanghari konflik pertanahan terbesar adalah antara Badan Hukum dengan masyarakat, persoalannya meliputi HGU dan proses kerjasama kemitraan.

\footnotetext{
${ }^{11}$ Diskusi di Kanwil BPN Jambi, 13 April 2011 dan di Kantor Pertanahan Muaro Jambi, 14 April 2011
} 
Berdasarkan Peraturan Pemerintah Nomor 38 Tahun, ada 9 item tugas BPN yang diserahkan ke Pemda yang kemudian menjadi tugas pokok Asisten I dan Asisten II, beberapa diantaranya adalah Tata ruang, Hak ulayat, Pembukaan lahan, Konflik pertanahan, dan lain-lain. Di Batanghari, Asisten I membentuk tim yang bersifat insindental untuk menyelesaikan konflik pertanahan secara mediasi. Selain itu ada pula Tim Pengawasan, Pembinaan dan Penyelesaian Permasalahan Perkebunan.

Tabel 6. Konflik Pertanahan yang Dimediasi Pemerintah Kabupaten

\begin{tabular}{|c|c|c|c|}
\hline No & Nama Perusahaan & Permasalahan & Hasil Mediasi \\
\hline 1 & $\begin{array}{l}\text { Tunjuk Lestari (TLS) } \\
\text { Sejahtera }\end{array}$ & $\begin{array}{l}\text { Kemitraan melalui KKPA pada tahun } \\
1994 / 1995 \text { di areal } 8.900 \text { ha, dengan } \\
\text { komposisi } 30 \% \text { untuk perusahaan } \\
\text { dengan HGU inti dan } 70 \% \text { untuk } \\
\text { masyarakat dengan HGU plasma. } \\
\text { Yang di HGU plasma mengalami } \\
\text { masalah berupa pembangunan } \\
\text { perkebunan yang tertatih-tatih, } \\
\text { tanaman tidak sesuai dan petani tidak } \\
\text { mendapatkan lahan }\end{array}$ & $\begin{array}{llr}\text { 1. } & \text { Kebun yang tidak } \\
\text { terbangun akan di bangun } \\
\text { dibawah pengawasan } \\
\text { Pemda; } \\
\text { 2. } & \begin{array}{l}\text { Penyelesaian } \\
\text { melalui } \\
\text { proposional }\end{array} & \text { hutang } \\
& \text { konversi }\end{array}$ \\
\hline 2 & Sawit Jaya Makmur & $\begin{array}{l}\text { HGU No. } 18 \text { tahun } 1997 \text { di areal seluas } \\
14.025 \text { ha untuk perkebunan inti } \\
\text { murni, } 40 \% \text { terindikasi terlantar. } \\
\text { Lahan yang terlantar dalam situasi } \\
\text { diokupasi oleh masyarakat dan sisanya } \\
\text { ditumbuhi semak belukar. Mendengar } \\
\text { adanya PP tentang Penertiban dan } \\
\text { Pendayagunaan Tanah Terlantar, } \\
\text { perusahaan membuka lahan yang } \\
\text { bersentuhan dengan lahan yang } \\
\text { diokupasi masyarakat }\end{array}$ & $\begin{array}{lll}\text { Perusahaan tidak } & \text { boleh } \\
\text { memperluas lahan di lahan } \\
\text { okupasi masyarakat }\end{array}$ \\
\hline
\end{tabular}

\subsubsection{Provinsi Sulawesi Utara}

Dalam kasus Maskeret, yaitu tanah konversi hak barat yang diokupasi warga semenjak tahun 1960. Putusan pengadilan menyatakan konversi hak barat tersebut adalah sah. Putusan Gelar Perkara di BPN Pusat merekomendasikan Kanwil BPN Sulut atau Kantah Kota Manado menjadi mediator, karena konversi sah (masyarakat tidak bisa membatalkan hak). Namun Notulen Gelar Perkara berbunyi konversi tidak sah.

Kantor Pertanahan Kota Manado juga memediasi konflik antara Pemda dengan pengembang terkait reklamasi pantai di Kota Manado, status tanah hasil reklamasi berupa Hak Pengelolaan (HPL) diperoleh Pemda.

\subsubsection{Provinsi Banten}




\section{Tabel 7. Beberapa Penanganan Sengketa, Konflik Kantor Pertanahan Di Kabupaten Tangerang Tahun 2011}

\begin{tabular}{|c|c|c|c|c|c|c|}
\hline $\begin{array}{l}\mathrm{N} \\
\mathrm{o}\end{array}$ & Para Pihak & Pokok Masalah & $\begin{array}{c}\text { Jenis } \\
\text { Masalah }\end{array}$ & $\begin{array}{l}\text { Letak \& Luas } \\
\text { Tanah }\end{array}$ & $\begin{array}{c}\text { Upaya } \\
\text { Penyelesaian }\end{array}$ & Keterangan \\
\hline 1. & $\begin{array}{l}\text { Yohanes } \\
\text { Indrayono vs } \\
\text { Abdul Kodir }\end{array}$ & $\begin{array}{l}\text { Tumpang Tindih } \\
\text { antara sertipikat HM } \\
\text { dengan sertipikat } \\
\text { HGB dalam satu } \\
\text { wilayah yang sama. }\end{array}$ & Sengketa & $\begin{array}{l}\text { Ds Kedaung Kec. } \\
\text { Pamulang } \\
\text { Luas : } 840 \mathrm{M} 2\end{array}$ & Mediasi & $\begin{array}{l}\text { Telah diundang mediasi } \\
\text { tetapi pihak Kantah dan } \\
\text { Yohanes (pelapor) } \\
\text { kesulitan mencari alamat } \\
\text { Abdul kodir, sebab di } \\
\text { cari di alamat yg } \\
\text { diwarkah tidak } \\
\text { diketemukan. }\end{array}$ \\
\hline 2. & $\begin{array}{l}\text { Hadi Arsali vs } \\
\text { PT. Alfa } \\
\text { Goldland } \\
\text { Serpong } \\
\text { (Alam Sutera) }\end{array}$ & $\begin{array}{l}\text { Sengketa Penguasaan } \\
\text { kepemilikan antara } \\
\text { tanah adat dengan } \\
\text { HGB }\end{array}$ & Sengketa & $\begin{array}{l}\text { Kel. Pakulonan } \\
\text { Kec. Serpong Utara } \\
\text { Luas : } 2.670 \mathrm{M} 2\end{array}$ & Mediasi & Mediasi Lanjutan \\
\hline 3. & $\begin{array}{l}\text { Dadang } \\
\text { Abuhanifah } \\
\text { Zachri, BA vs } \\
\text { Ir. Ida Bagus } \\
\text { Rajendra } \\
\text { Wesnawa }\end{array}$ & $\begin{array}{l}\text { Penguasaan dan } \\
\text { pemilikan tanah } \\
\text { berdasarkan } \\
\text { Girik/Letter C desa }\end{array}$ & Sengketa & $\begin{array}{l}\text { Ds. Pondok Karya } \\
\text { Kec. Pondok Aren } \\
\text { Luas : } 602 \text { M2 }\end{array}$ & Mediasi & $\begin{array}{l}\text { Pihak Pelapor } \\
\text { mengajukan gugatan ke } \\
\text { PTUN (selesai) }\end{array}$ \\
\hline 4. & $\begin{array}{l}\text { Ujang } \\
\text { Zulkarnaen vs } \\
\text { PT. Reni Jaya }\end{array}$ & $\begin{array}{l}\text { Tumpang tindih } \\
\text { antara SHM No. } 272 \\
\text { dengan HGB a.n PT. } \\
\text { Reni Jaya }\end{array}$ & Sengketa & $\begin{array}{l}\text { Kel. Pondok Benda } \\
\text { Kec. Ciputat Kota }\end{array}$ & Mediasi & $\begin{array}{l}\text { Dua mediasi terakhir } \\
\text { bulan maret tetapi tdk } \\
\text { ada kesepakatan } \\
\text { disarankan untuk ke } \\
\text { Pengadilan (selesai) }\end{array}$ \\
\hline
\end{tabular}

Kendala yang dihadapi Kantor Pertanahan dalam penyelesaian konflik pertanahan, antara lain:

1). Penyelesaian hanya dalam formal, meski kasus tidak selesai.

2). Suatu kasus bisa penanganannya selesai, tapi kasusnya tidak selesai.

3). Kesulitan mengikuti Petunjuk Teknis.

4). Volume pekerjaan yang tidak sesuai dengan jumlah staf.

5). Apakah BPN tidak bisa menentukan benar dan salahnya sebuah kasus. 
6). Pihak pelapor sering tidak datang ketika diundang mediasi tanpa laporan alasan ketidakhadirannya.

\subsubsection{Provinsi Papua}

Mediasi yang telah dilakukan oleh BPN Provinsi Jayapura antara lain terhadap :

- Konflik bandara sentani, yang pada tahun 2001 telah dibayarkan ganti rugi kepada masyarakat sebesar 15 milyar, namun kemudian pada tahun 2009 kembali masyarakat menuntut ganti rugi sebesar 72 milyar, sudah dilakukan mediasi namun sampai saat ini belum dicapai titik temu.

- Kasus tanah Pemda di kecamatan sentani yang berhadapan dengan masyarakat suku ongge, telah dilakukan gelar perkara di Kanwil BPN Provinsi pada tahun 2008 dan di BPN Pusat pada tahun 2010, yanghasilnya pembatalan sertipikat atas nama Elias Ongge di atas tanah Pemda.

\subsubsection{Provinsi Bali}

Terhadap konflik di Desa Adat Lemukih Kecamatan Sawan Kabupaten Buleleng yang pada akhirnya dilakukan upaya mediasi yang diketuai oleh Gubernur Bali dengan mengundang beberapa pihak yang terkait diantaranya adalah :

- Ketua Komisi I DPRD Prov. Bali

- Kapolda Bali

- Bupati Buleleng

- Kapolres Buleleng

- Tim Investigasi masalah Lemukih

- Asisten Pemerintahan Sekda Prov. Bali

- Ka Kanwil BPN Prov. Bali

- Kepala Badan Kesbangpol dan Linmas Prov. Bali

- Kepala Biro Pemerintahan Setda Prov. Bali

- Kepala Biro Ekonomi dan Pembangunan Setda Prov. Bali

- Kepala Biro Humas dan Protokol Setda Prov. Bali

- Kepala Badan Kesbangpol dan Linmas Kab. Buleleng

- Kepala Kantor Pertanahan Kab. Buleleng

- Camat Sawan Kab. Buleleng

- Kepala Desa Lemukih, Kecamatan Sawan Kab. Buleleng 
- Bendesa Pekraman Lemukih Kec. Sawan Kab. Buleleng

Walaupun telah berkali-kali dilakukan upaya mediasi namun sampai saat ini konflik belum juga dapat diselesaikan.

\section{BAB V PEMBAHASAN}

\subsection{Identifikasi Konflik}

Konflik secara harfiah diartikan secara luas oleh masyarakat, yaitu setiap pertentangan yang terjadi diantara dua pihak atau lebih karena adanya perbedaan pandangan sehingga konflik juga identik dengan permasalahan pertanahan. Luasnya pengertian konflik perlu diberikan batasan yang konkrit untuk membedakan dengan kasus pertanahan.

Pengertian konflik pertanahan kemudian didefinisikan dan dituangkan kedalam Peraturan Kepala Badan Pertanahan Nasional No. 3 tahun 2011 tentang Pengelolaan Pengkajian Dan Penanganan Kasus Pertanahan. Dalam Perkaban tersebut, dicantumkan bahwa Kasus Pertanahan adalah sengketa, konflik, atau perkara pertanahan yang disampaikan kepada Badan Pertanahan Nasional Republik Indonesia untuk mendapatkan penanganan penyelesaian sesuai ketentuan peraturan perundang-undangan dan/atau kebijakan pertanahan nasional.

Selanjutnya dalam pasal 1 point 3 dicantumkan bahwa konflik pertanahan yang disingkat konflik adalah perselisihan pertanahan antara orang perseorangan, kelompok, golongan, organisasi, badan hukum, atau lembaga yang mempunyai kecenderungan atau sudah berdampak luas secara sosio-politis. Dalam pasal 1 point 2 disebutkan bahwa sengketa pertanahan yang selanjutnya disingkat sengketa adalah perselisihan pertanahan antara orang perseorangan, badan hukum, atau lembaga yang tidak berdampak luas secara sosio-politis. Kemudian dalam point 4 mengenai

Perkara Pertanahan yang selanjutnya disingkat Perkara adalah perselisihan pertanahan yang penyelesaiannya dilaksanakan oleh lembaga peradilan atau putusan lembaga peradilan yang masih dimintakan penanganan perselisihannya di Badan Pertanahan Nasional Republik Indonesia. Dari pengertian tersebut di atas, terlihat bahwa perbedaan sengketa dengan konflik adalah terletak pada a) dampaknya, dimana konflik mempunyai dampak yang luas secara sosiopolitis, b) antara kelompok, golongan dan organisasi, yang berarti melibatkan banyak orang(massal). 
Dari data kasus pertanahan tahun 2007 menunjukkan bahwa jumlah kasus pertanahan adalah sebagai berikut :
a. Sengketa : 4.581 kasus
b. Konflik : 858 kasus
c. Perkara : 2.052 kasus

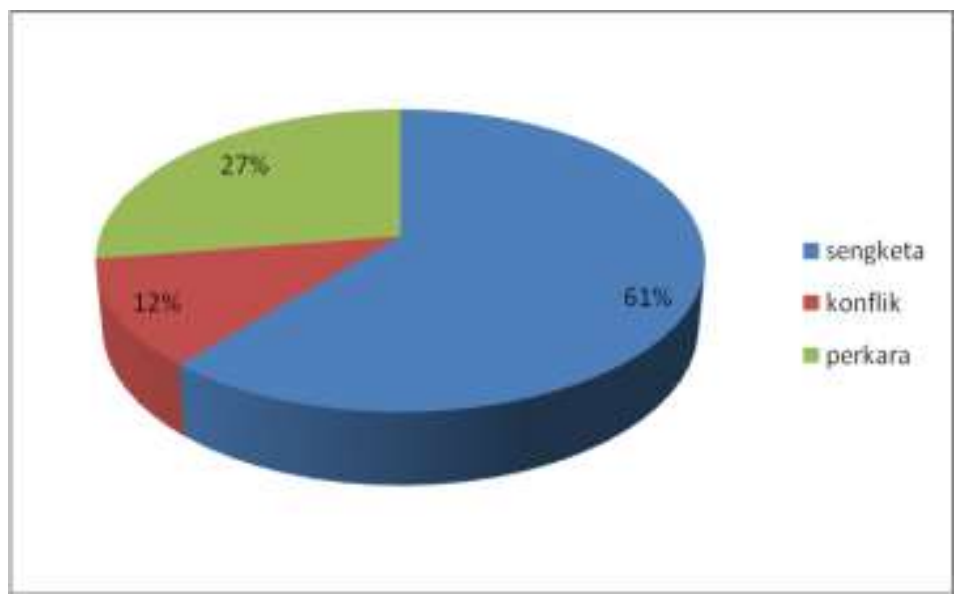

Gambar 1. Kasus Pertanahan

Dari gambar di atas menunjukkan bahwa kuantitas konflik sangat kecil dibandingkan dengan perkara apalagi sengketa, demikian juga hasil pengumpulan data di 14 lokasi penelitian menunjukkan bahwa jumlah/kuantitas konflik pertanahan jauh lebih kecil dibandingkan perkara dan sengketa, tidak lebih dari 10 kasus konflik untuk setiap kota dan kabupaten tahun 2007 sampai 2010 yaitu sejak dibentuknya Deputi Bidang Pengkajian dan Penanganan Sengketa dan Konflik Pertanahan. Walaupun sangat kecil, namun tingkat penyelesaiannya sangat rendah dibandingkan perkara dan sengketa. Sengketa relatif lebih mudah untuk diselesaikan secara mediasi karena tidak melibatkan orang banyak/kelompok.

\subsection{Bentuk/tipologi permasalahan dan akar permasalahan}

Tipologi konflik pertanahan yang ditemukan di lokasi penelitian, hampir seluruhnya merupakan penguasaan dan pemilikan tanah, dan juga ditemukan tipologi masalah batas/letak dan bidang tanah, dan masalah tanah ulayat ditemukan di Papua.

Tabel. 8. Tipologi/Bentuk Konflik 


\begin{tabular}{|l|l|c|c|c|c|c|c|}
\hline \multirow{2}{*}{ No. } & \multirow{2}{*}{ Provinsi } & \multicolumn{5}{|c|}{ Tipologi/Bentuk Konflik } & \multirow{2}{*}{ Jumlah } \\
\cline { 3 - 7 } & Pemilikan & $\begin{array}{c}\text { Penetapan } \\
\text { hak dan PT }\end{array}$ & $\begin{array}{c}\text { Batas/ } \\
\text { letak }\end{array}$ & Ulayat & $\begin{array}{c}\text { Putusan } \\
\text { Pengadilan }\end{array}$ & \\
\hline 1 & Jambi & 11 & 3 & - & - & - & 14 \\
\hline 2 & $\begin{array}{l}\text { Sulawesi } \\
\text { Utara }\end{array}$ & 5 & - & 2 & - & 1 & 8 \\
\hline 3 & Banten & 5 & - & 1 & - & - & 6 \\
\hline 4 & Papua & 2 & & & 1 & & 3 \\
\hline 5 & Bali & 3 & - & - & - & - & 3 \\
\hline & Jumlah & 27 & 3 & 3 & - & 1 & 34 \\
\hline
\end{tabular}



\section{Gambar 2. Tipologi/bentuk Konflik}

\subsection{Akar masalah, tahapan kasus dan para pihak yang bersengketa}

Mencermati konflik yang terjadi di lima lokasi penelitian, yang berkaitan dengan konflik penguasaan dan pemilikan tanah, diperoleh akar masalah terjadinya konflik tersebut, tahapan penyelesaian yang sedang dilakukan hingga saat ini, serta para pihak yang terkait dalam konflik tersebut.

Tabel 9. Akar masalah, tahapan kasus dan para pihak yang bersengketa

\begin{tabular}{|l|l|l|ll|}
\hline No. & Akar masalah & Tahapan kasus & Para pihak \\
\hline 1. & $\begin{array}{l}\text { Masalah okupasi tanah HGU } \\
\text { oleh rakyat, yang menuntut } \\
\text { HGU tidak diperpanjang }\end{array}$ & $\begin{array}{l}\text { Mediasi dengan tuntutan } \\
\text { tanah yang digarap } \\
\text { petani diredistribusikan } \\
\text { kepada para petani } \\
\text { penggarap. }\end{array}$ & $\begin{array}{l}\text { Badan hukum vs } \\
\text { masyarakat }\end{array}$ & \\
& $\begin{array}{l}\text { Pengaduan masyarakat untuk } \\
\text { pengembalian lahan kebun } \\
\text { sawit yang menurut }\end{array}$ & $\begin{array}{l}\text { Mediasi dengan janji } \\
\text { akan dilakukan } \\
\text { identifikasi mengenai }\end{array}$ & $\begin{array}{l}\text { Badan Hukum vs } \\
\text { masyarakat desa }\end{array}$ \\
\hline 2.
\end{tabular}




\begin{tabular}{|c|c|c|c|}
\hline & $\begin{array}{lll}\text { masyarakat } & \text { adalah } & \text { milik } \\
\text { mereka } & & \end{array}$ & $\begin{array}{l}\text { penguasaan pemilikan } \\
\text { tanah masyarakat yang } \\
\text { dienclave dalam } \mathrm{HGU}\end{array}$ & \\
\hline 3. & $\begin{array}{l}\text { Pembagian kebun plasma } \\
\text { kepada masyarakat adat (Suku } \\
\text { Anak dalam) }\end{array}$ & $\begin{array}{lr}\text { Mediasi dengan } & \begin{array}{r}\text { janji, } \\
\text { akan }\end{array} \\
\text { Perusahaan } & \text { kebun } \\
\text { menyerahkan } & \text { ker } \\
\text { kelapa sawit } 1000 \text { ha } \\
\text { kepada SAD }\end{array}$ & $\begin{array}{l}\text { Badan Hukum vs } \\
\text { masyarakat adat }\end{array}$ \\
\hline 4. & $\begin{array}{lr}\text { Tuntutan pola kemitraan } \\
\text { dengan proporsi } 30 \% \text { untuk } \\
\text { perusahaan, } 70 \% & \text { untuk } \\
\text { masyarakat, ternyata kebun } \\
\text { yang diserahkan kepada } \\
\text { masyarakat belum siap(tanam } \\
\text { tumbuhnya } \\
\text { sesuai)sehingga hutang tidak } \\
\text { dapat dibayar }\end{array}$ & $\begin{array}{l}\text { Mediasi dengan janji, } \\
\text { Perusahaan } \\
\text { membangun kebun yang } \\
\text { belum terbangun, dan } \\
\text { terhadap hutang akan } \\
\text { dilakukan verifikasi data } \\
\text { angsuran yang sudah } \\
\text { dibayar }\end{array}$ & $\begin{array}{lr}\text { Badan Hukum vs } \\
\text { Kelompok } & \text { masyarakat } \\
\text { (kel. Tani) } & \end{array}$ \\
\hline 5. & $\begin{array}{l}\text { Obyek sengketa adalah bekas } \\
\text { Hak Barat (Eigendom) yang } \\
\text { selama ini dihuni oleh para } \\
\text { Veteran Trikora. } \\
\text { berpegang pada Undang- } \\
\text { Undang No. } 1 \text { Tahun 2004, } \\
\text { bahwa asetnya ini masuk } \\
\text { dalam Inventaris Kekayaan } \\
\text { Milik Negara (IKMN) }\end{array}$ & PTUN & $\begin{array}{l}\text { Instansi pemerintah vs } \\
\text { masyarakat (pensiunan) }\end{array}$ \\
\hline 6. & $\begin{array}{l}\text { tanah konversi hak barat yang } \\
\text { diokupasi } \quad \text { warga } r \text { semenjak } \\
\text { tahun } 1960\end{array}$ & $\begin{array}{lr}\text { Putusan } & \text { pengadilan } \\
\text { menyatakan } \quad \text { konversi } \\
\text { tersebut sah. Gelar } \\
\text { perkara sudah dilakukan } \\
\text { di BPN Pusat. }\end{array}$ & $\begin{array}{l}\text { Perorangan } \\
\text { masyarakat }\end{array}$ \\
\hline 7. & $\begin{array}{l}\text { tanah yang dikuasai Pertamina } \\
\text { semenjak tahun } 1967 \text {, dan kini } \\
\text { digugat oleh } 300 \text { orang ahli } \\
\text { waris }\end{array}$ & $\begin{array}{l}\text { putusan pengadilan } \\
\text { menyatakan Pertamina } \\
\text { harus keluar dari lahan } \\
\text { dan membayar ganti } \\
\text { rugi. Pertamina tidak } \\
\text { mau keluar lahan dan } \\
\text { terus menegosiakan } \\
\text { angka ganti rugi. }\end{array}$ & Pertamina vs masyarakat \\
\hline 8. & $\begin{array}{l}\text { Tanah yang ada di } 6 \text { desa } \\
\text { diklaim sebagai } \\
\text { kehutanan (TNUK) }\end{array}$ & Belum dilakukan mediasi & $\begin{array}{l}\text { Masyarakat dengan } \\
\text { Instansi pemerintah }\end{array}$ \\
\hline 9. & $\begin{array}{l}\text { tanah-tanah milik Pura dalam } \\
\text { pensertipikatannya ditempuh } \\
\text { melalui jalur konversi, jika } \\
\text { akan dialihkan menjadi milik } \\
\text { perorangan harus melalui } \\
\text { peralihan hak. }\end{array}$ & $\begin{array}{lr}\text { Mediasi } & \text { dilakukan } \\
\text { namun belum ada } \\
\text { kesepakatan }\end{array}$ & $\begin{array}{l}\text { Perorangan dengan Desa } \\
\text { Adat }\end{array}$ \\
\hline 10. & $\begin{array}{l}\text { Tanah untuk lapangan golf } \\
\text { diklaim masyarakat sebagai } \\
\text { tempat sarana ibadah }\end{array}$ & $\begin{array}{l}\text { Mediasi sudah selesai, } \\
\text { dengan mengganti tanah } \\
\text { masyarakat/di relokasi }\end{array}$ & $\begin{array}{l}\text { Badan Hukum } \\
\text { Masyarakat }\end{array}$ \\
\hline
\end{tabular}




\begin{tabular}{|l|l|l|l|}
\hline 11. & $\begin{array}{l}\text { HGU yang sudah habis } \\
\text { waktunya dan diokupasi oleh } \\
\text { masyarakat }\end{array}$ & Pengadilan & $\begin{array}{l}\text { Pemda Provinsi vs } \\
\text { Badan Hukum }\end{array}$ \\
\hline 12. & $\begin{array}{l}\text { Pengadaan tanah untuk } \\
\text { waduk karian, pemegang } \\
\text { haknya sudah beralih } \\
\text { namun belum balik nama }\end{array}$ & Mediasi & $\begin{array}{l}\text { Pemda vs badan Hukum } \\
\text { vs masyarakat }\end{array}$ \\
\hline
\end{tabular}

Dari beberapa gambaran konflik di atas, seluruhnya sangat sulit untuk diselesaikan, hanya satu kasus yang akhirnya dapat diselesaikan tuntas, bahkan untuk konflik yang sudah coba dilakukan melalui pengadilan menemui kendala dalam eksekusinya.

Berdasarkan pengamatan peneliti, akar permasalahan dari konflik pertanahan dapat dikelompokkan dalam beberapa kelompok :

1) Konflik atas tanah masyarakat yang diklaim masuk dalam kawasan hutan

2) Konflik di areal HGU, baik yang sudah habis masa berlakunya maupun yang belum habis dan belum diperpanjang

3) Konflik pemegang HGU dengan masyarakat sebagai akibat pelaksanaan dari pola kemitraan

4) Konflik mengenai tanah bekas hak barat (konversi) yang tumpang tindih dengan tanah masyarakat

5) Konflik atas desa adat dengan masyarakat desa adat, desa adat tidak boleh memiliki hak Milik tetapi tanah laba pura yang berada di bawah desa adat dapat menjadi Hak Milik

6) Konflik di Papua, sebagai akibat adanya New York Agreement tahun 1966 yang dikuatkan oleh PBB dan diratifikasi menjadi UU No. 7 tahun 1966 tentang Persetujuan antara Pemerintah penjajahan Belanda dan pemerintah Kerajaan belanda dengan pemerintah Republik Indonesia tentang soal-soal keuangan, dengan adanya agreement ini maka status tanah peninggalan menjadi tanah yang langsung dikuasai oleh Negara RI. Selain itu, ada pula persetujuan Overeenkomst Juli 1956 dan tahun 1962, yaitu persetujuan penyerahan tanah masyarakat hukum adat kepada pemerintah jajahan Belanda. Berdasarkan overeenkomst tersebut, maka sebagian besar tanah di wilayah Kota Jayapura adalah berstatus tanah yang langsung dikuasai oleh Negara, hanya saja dalam overeenkomst tersebut tidak dijelaskan batas-batasnya secara tegas tetapi hanya ditandai dengan batas-batas alam, sehingga menyebabkan sering timbul masalah batas antara pemerintah dengan masyarakat.

Adapun para pihak yang terkait dalam konflik tersebut di atas :

Badan hukum vs masyarakat (desa/adat)

Badan hukum vs kelompok masyarakat 
Instansi pemerintah vs Masyarakat

BUMN vs masyarakat

Instansi Pemerintah vs Badan Hukum

Perorangan vs Masyarakat Desa Adat

Pemda vs Badan Hukum vs Masyarakat

Bentuk penyelesaian konflik pertanahan yang ditemukan umumnya dilakukan secara non litigasi yaitu melalui upaya mediasi dengan melibatkan beberapa pihak

\subsection{Upaya Penyelesaian melalui proses alternatif berbasis masyarakat}

Upaya penyelesaian konflik yang terjadi di masyarakat melalui proses berbasis masyarakat, peneliti temukan di beberapa daerah yaitu :

\subsubsection{Bali}

Untuk konflik yang terjadi di masyarakat diselesaikan melalui lembaga adat yang dikenal dengan Majelis Desa Pakraman atau MDP adalah merupakan organisasi yang bersifat religius. Majelis Desa Pakraman terdiri dari:

1. Majelis Utama, berkedudukan di ibukota Propinsi Bali yang selanjutnya disingkat dengan MDP Bali.

2. Majelis Madya, berkedudukan di ibukota kabupaten/kota selanjutnya disingkat MDP/Kota

3. Majelis Desa, berkedudukan di ibukota kecamatan selanjutnya disingkat MDP Kecamatan.

Tugas dan wewenang MDP antara lain adalah

1. Melestarikan Lingkungan dan tanah Bali

2. Memusyawarahkan berbagai hal yang menyangkut masalah-masalah adat dan agama untuk kepentingan desa pakraman.

3. Sebagai penengah dalam kasus-kasus adat yang tidak dapat di selesaikan pada tingkat desa

Lembaga ini ternyata cukup efektif untuk mengatasi permasalahan termasuk konflik tanah yang terjadi di masyarakat.

\subsubsection{Minahasa Utara}


Di wilayah ini dikenal hukumtua yang menangani permasalahan di desa termasuk konflik pertanahan.

Hukumtua adalah pemimpin desa milik semua warga. Seorang hukumtua harus bisa merangkul semua elemen masyarakat di desanya untuk melaksanakan kegiatan yang bermuara pada peningkatan kesejahteraan masyarakat.

\subsubsection{Papua}

Dikenal adanya struktur lembaga masyarakat hukum adat



- Ondoafi/ondofolo = bertanggung jawab ke luar dan ke dalam, ada pada masing-masing marga

- Koselo = kepala suku

- Ondoavi = yang mengurus tanah

Dalam penyelesaian konflik di setiap kampung bisa dilakukan melalui Para-para Adat.. Parapara adat akan mempelajari konflik yang terjadi dan mencoba untuk mencari jalan keluarnya. Yang termasuk dalam para-para adat adalah ondoavi dan mata rumah, hanya saja istilah ondoavi ini berbeda-beda untuk setiap suku, adalah suku di Jayapura yang menggunakan istilah ondoavi.

\subsubsection{Muaro Jambi}

Di daerah ini masyarakat pada umumnya tidak mengadu ke BPN karena ada tim sengketa Kabupaten, dalam tim ini BPN termasuk sebagai anggota yang menyediakan data berupa peta jika diperlukan. Tingkatan penyelesaian sengketa dimulai dari tingkat desa, jika terjadi konflik maka akan di mediasi di tingkat desa. Apabila tidak ada penyelesaian juga maka di naikkan ke 
tingkat kecamatan. Kalau terjadi sengketa yang terkait perkebunan maka diajukan langsung ke tim sengketa Kabupaten.

Dari berbagai model penyelesaian konflik pertanahan yang ada di atas, efektif dapat menyelesaikan kasus-kasus yang terkait dengan sengketa perorangan, tetapi jika sudah menyangkut kelompok masyarakat, penyelesaian konflik relative sulit dicapai. Sulitnya menyelesaikan konflik menggambarkan bahwa tatanan kepatuhan dalam masyarakat semakin berkurang. Kearifan lokal seperti nilai-nilai kemanusiaan, kebersamaan, persaudaraan dan sikap ketauladanan lainnya mulai banyak terkikis di dalam lingkungan budaya masyarakat. Visi dan ideologi pembangunan yang lebih mendepankan pertumbuhan ekonomi, perkembangan fisik, dan material dibandingkan dengan nilai spritualitas dan kearifan lokal (local wisdom) mempengaruhi cara berfikir dan bertindak sebagaian besar anggota masyarakat.

\subsection{Pihak pihak yang seharusnya ikut berperan serta dalam penyelesaian konflik pertanahan didalam masyarakat}

Konflik Pertanahan menyangkut lintas sektoral, oleh karena itu penanganannya melibatkan banyak pihak, tidak hanya BPN dan masyarakat yang berkonflik.

Dalam PP No. 38 tahun 2007 tentang Pembagian Urusan Pemerintahan Antara Pemerintah, Pemerintahan Daerah Provinsi, dan Pemerintahan Daerah Kota/Kabupaten dinyatakan bahwa kewenangan Pemerintah di bidang pertanahan dilaksanakan oleh Pemerintah Kabupaten/Kota.Kewenangan sebagaimana dimaksud adalah :

1. pemberian ijin lokasi;

2. penyelenggaraan pengadaan tanah untuk kepentingan pembangunan;

3. penyelesaian sengketa tanah garapan;

4. penyelesaian masalah ganti kerugian dan santunan tanah untuk pembangunan;

5. penetapan subyek dan obyek redistribusi tanah, serta ganti kerugian tanah kelebihan maksimum dan tanah absentee;

6. penetapan dan penyelesaian masalah tanah ulayat;

7. pemanfaatan dan penyelesaian masalah tanah kosong;

8. pemberian ijin membuka tanah;

9. perencanaan penggunaan tanah wilayah Kabupaten/Kota.

Berdasarkan kewenangan tersebut maka Pemerintah Daerah membentuk Tim Penyelesaian Sengketa dan Konflik Pertanahan.

Jambi sebagai Provinsi yang cukup tinggi angka konflik terutama yang terkait dengan tanah perkebunan sudah mengeluarkan SK Gubernur No. 96/Kep.Gub/Ekbang-SDA/2011 
tentang Pembentukan Tim Inventarisasi, Pengkajian dan Mediasi Konflik Lahan di Provinsi Jambi. Tim sengketa terdiri dari 1)Tim Koordinasi, 2) Pokja Inventarisasi dan Pengkajian,3) Pokja Fasilitasi dan Mediasi, 4) Sekretariat. Tugas dari Tim Sengketa antara lain, 1)melakukan koordinasi dengan seluruh komponen stakeholder dalam rangka penyelesaian konflik, 2) melakukan inventarisasi dan pengkajian konflik lahan yang terjadi di Provinsi Jambi, 3) memetakan konflik sesuai dengan kewenangan dan memeberikan rekomendasi kepada daerah Provinsi /Kabupaten/Kota untuk menyelesaikan konflik sesuai dengan kewenangannya, 4)melakukan fasilitasi dan mediasi dalam rangka penyelesaian konflik, 5) memberikan pendapat, saran dan pertimbangan hokum terkait dengan konflik lahan baik kepada Pemerintah, pengusaha ataupun kepada masyarakat, 6) melaporkan hasil kerjanya kepada Gubernur.

Tim di atas walaupun baru dibentuk namun cukup sukses menangani konflik yang ada walaupun belum tuntas.

Papua juga sudah mengeluarkan Keputusan Gubernur No. 189 tahun 2009 tentang Pembentukan Tim terpadu Penyelesaian Masalah-masalah Pertanahan di Provinsi Papua. Tugas dari Tim ini adalah 1) mengidentifikasi masalah-masalah pertanahan di Provinsi Papua, 2) membahas dan mengkaji masalah-masalah pertanahan di Provinsi Papua, 3) memberikan saran pertimbangan kepada Gubernur Provinsi Papua untuk penyelesaian masalah pertanahan di Provinsi Papua. Yang termasuk sebagai Dewan Pembina Tim yaitu Gubernur, Wakil Gubernur, Ketua DPR Papua, dan Ketua Majelis Rakyat Papua.

Untuk ke-tiga daerah lainnya belum ada Peraturan Gubernur mengenai Tim Sengketa.

\subsection{Kekuatan hukum Mediasi}

Penyelesaian konflik berbasis masyarakat dilakukan melalui mediasi. Mediasi secara implicit diatur dalam Peraturan Presiden No. 10 tahun 2006 dan Perkaban No. 3 tahun 2011 tentang Pengelolaan Pengkajian Dan Penanganan Kasus Pertanahan.

Setiap permohonan konflik yang masuk ke BPN diupayakan untuk dilakukan penyelesaian melalui cara mediasi. Dalam pasal 39 Perkaban Nomor 3 tahun 2011 ayat (1) dicantumkan bahwa Gelar Mediasi bertujuan:

a. menampung informasi/pendapat dari semua pihak yang berselisih dan pendapat dari unsur lain yang perlu dipertimbangkan;

b. menjelaskan posisi hukum para pihak baik kelemahan/kekuatannya;

c. memfasilitasi penyelesaian kasus pertanahan melalui musyawarah dan

d. pemilihan penyelesaian kasus pertanahan.

Dalam hal Gelar Mediasi tidak dapat dihadiri oleh salah satu pihak yang berselisih, pelaksanaannya dapat ditunda agar semua pihak yang berselisih dapat hadir. Apabila pihak yang berselisih sudah diundang 3 (tiga) kali secara patut tidak hadir dalam Gelar Mediasi maka mediasi tetap diselenggarakan.

Di Kota jambi, kasus yang dapat diselesaikan secara mediasi dicapai melalui 3 kali pertemuan, pertemuan pertama dilakukan pemanggilan saksi-saksi dan para pihak untuk mendata 
informasi dari kedua, pertemuan kedua membahas posisi para pihak berdasarkan data awal yang diajukan, pertemuan ketiga, melakukan analisa konflik dan ditawarkan kesepakatan diantara para pihak. Jika para pihak sepakat damai maka dibuatkan Berita Acara Mediasi.

Di kota Tangerang, kasus yang dapat dimesdiasi dicapai melalui pertemuan sebanyak 3 kali yang menghasilkan kesepakatan diantara para pihak yang dituangkan dalam bentuk surat Perjanjian Penyelesaian Sengketa (Perdamaian).

Jika kasus selesai dengan mediasi maka termasuk criteria K3.

Penanganan konflik dilakukan dengan jangka waktu penyelesaian paling lama 3 (tiga) bulan sejak diterimanya pengaduan atau informasi sengketa. Untuk penanganan kasus pertanahan yang bersifat rawan, strategis, atau yang mempunyai dampak luas. batas waktu penyelesaian dapat diperpanjang dengan persetujuan Kakan, Kakanwil atau Deputi.

Jika tidak tercapai perdamaian diantara para pihak yang bersengketa/konflik maka disarankan untuk diselesaikan melalui jalur Pengadilan, atau disebut criteria K4 (Jalur hukum).

Di Pengadilan, setiap sengketa perdata yang diajukan di depan hakim, hakim selalu mengusulkan untuk penyelesaian secara damai oleh para pihak (Pasal $130 \mathrm{HIR}$ ).

Dalam Pasal 17 ayat (1) disebutkan bahwa jika mediasi menghasilkan kesepakatan, para pihak dengan bantuan mediator wajib merumuskan secara tertulis kesepakatan yang dicapai dan ditandatangani oleh para pihak, selanjutnya ayat (5) dicantumkan para pihak dapat mengajukan kesepakatan perdamaian kepada Hakim untuk dikuatkan dalam akta perdamaian.

Walaupun sudah dibuat Berita Acara Perdamaian, masih sering terjadi para pihak mengingkari atau tidak melaksanakan apa-apa yang telah mereka sepakati.

KUH Perdata mengatur dan menentukan persyaratan syahnya suatu perdamaian secara limitative seperti yang termuat dalam pasal. 1320, 1321, 1851-1864.18

a. Perdamaian harus atas persetujuan kedua belah pihak

Unsur-unsur persetujuan yakni adanya kata sepakat secara sukarela (toesteming), kedua belah pihak cakap dalam membuat persetujuan (bekwamnied), objek persetujuan mengenai pokok yang tertentu (bepaalde onderwerp), berdasarkan alasan yang diperbolehkan (seorrlosofde oorzaak). Dengan demikian bahwa persetujuan-persetujuan tidak boleh terdapat cacat pada setiap unsure esensialnya suatu persetujuan. ${ }^{12}$

b. Perdamaian harus mengakhiri sengketa

Dalam pasal 130 HIR, Pasal 154 Rbg mengatakan bahwa apabila perdamaian telah dapat dilaksanakan, maka dibuat putusan perdamaian yang disebut dengan akte perdamaian.

12 Pada pasal 1321 KUH Perdata dipertegas bahwa persetujuan perdamaian itu sama sekali tidak boleh mengandung unsure kekeliruan (dwaling ) paksaan (dwang) dan penipuan (berdrog) 
Akte yang dibuat ini harus betul-betul dapat mengakhiri sengketa yang terjadi antara kedua belah pihak berperkara apabila tidak maka dianggap tidak memenuhi syarat formal, dianggap tidak syah dan tidak mengikat para pihak-pihak yang berperkara. Putusan perdamaian harus dibuat dalam persidangan majelis hakim, disinilah peran hakim sangat dibutuhkan dalam akte perdamaian ini dapat diwujudkan.

c. Perdamaian harus atas dasar keadaan sengketa yang telah ada

Syarat untuk dapat dasar suatu putusan perdamaian itu hendaklah atas dasar persengketaan para pihak yang sudah terjadi, baik yang sudah terwujud maupun yang sudah nyata terwujud tapi baru akan diajukan ke pengadilan.21 Sehingga perdamaian itu dapat mencegah gugatan atas perkara di pengadilan. Hal ini berarti bahwa perdamaian itu dapat lahir dari suatu perdata yang belum diajukan ke pengadilan.

Bentuk perjanjian damai yang dapat diajukan ke depan sidang pengadilan dapat saja dibuat dalam bentuk akta notaris atau akta dibawah tangan.

d. Bentuk perdamaian harus secara tertulis (akta perdamaian)

Dalam pasal $1851 \mathrm{KUH}$ perdata disebutkan bahwa persetujuan perdamaian itu sah apabila dibuat secara tertulis dengan format yang telah ditetapkan oleh ketentuan peraturan yang berlaku. Syarat ini sifatnya memaksa (inferatif), dengan demikian tidak ada persetujuan perdamaian apabila dilaksanakan secara lisan, meskipun dihadapan pejabat yang berwenang.

Dari pasal-pasal KUHPer di atas menunjukkan bahwa perdamaian yang dilahirkan berdasarkan kesepakatan diantara para pihak mengikat dan berlaku sebagai undang-undang bagi para pihak yang menyepakatinya.

Walaupun Mediasi sudah diatur dalam KUHPer dan Peraturan MA, namun karena belum dicantumkan dalam suatu undang-undang, menjadikan para pihak sering mengingkarinya.

Berkaitan dengan hal tersebut, kiranya penyelesaian kasus pertanahan melalui mediasi perlu dimasukkan dalam RUU Pertanahan, sehingga lebih mempunyai kekuatan hokum mengikat bagi para pihak yang terkait dan diberikan sanksi jika tidak dilaksanakan. 


\section{BAB VI \\ KESIMPULAN}

\subsection{Kesimpulan}

1. Hasil pengumpulan data di 14 lokasi penelitian menunjukkan bahwa jumlah/kuantitas konflik pertanahan jauh lebih kecil dibandingkan perkara dan sengketa, tidak lebih dari 10 kasus konflik untuk setiap kota dan kabupaten tahun 2007 sampai 2010 yaitu sejak dibentuknya Deputi Bidang Pengkajian dan Penanganan Sengketa dan Konflik Pertanahan. Walaupun sangat kecil, namun tingkat penyelesaiannya sangat rendah dibandingkan perkara dan sengketa. Sengketa relatif lebih mudah untuk diselesaikan secara mediasi karena tidak melibatkan orang banyak/kelompok.

2. Tipologi konflik pertanahan yang ditemukan di lokasi penelitian, hampir seluruhnya merupakan penguasaan dan pemilikan tanah, dan juga ditemukan tipologi masalah batas/letak dan bidang tanah, dan masalah tanah ulayat ditemukan di Papua.

3. Akar permasalahan dari konflik pertanahan dapat dikelompokkan dalam beberapa kelompok :

a. Konflik atas tanah masyarakat yang diklaim masuk dalam kawasan hutan

b. Konflik di areal HGU, baik yang sudah habis masa berlakunya maupun yang belum habis dan belum diperpanjang

c. Konflik pemegang HGU dengan masyarakat sebagai akibat pelaksanaan dari pola kemitraan

d. Konflik mengenai tanah bekas hak barat (konversi) yang tumpang tindih dengan tanah masyarakat

e. Konflik atas desa adat dengan masyarakat desa adat, desa adat tidak boleh memiliki hak Milik tetapi tanah laba pura yang berada di bawah desa adat dapat menjadi Hak Milik

f. Konflik di Papua, sebagai akibat adanya New York Agreement tahun 1966 yang dikuatkan oleh PBB dan diratifikasi menjadi UU No. 7 tahun 1966 tentang 
Persetujuan antara Pemerintah penjajahan Belanda dan pemerintah Kerajaan belanda dengan pemerintah Republik Indonesia tentang soal-soal keuangan, dengan adanya agreement ini maka status tanah peninggalan menjadi tanah yang langsung dikuasai oleh Negara RI. Selain itu, ada pula persetujuan Overeenkomst Juli 1956 dan tahun 1962, yaitu persetujuan penyerahan tanah masyarakat hukum adat kepada pemerintah jajahan Belanda. Berdasarkan overeenkomst tersebut, maka sebagian besar tanah di wilayah Kota Jayapura adalah berstatus tanah yang langsung dikuasai oleh Negara, hanya saja dalam overeenkomst tersebut tidak dijelaskan batasbatasnya secara tegas tetapi hanya ditandai dengan batas-batas alam, sehingga menyebabkan sering timbul masalah batas antara pemerintah dengan masyarakat.

4. Upaya penyelesaian konflik yang terjadi di masyarakat melalui proses berbasis masyarakat, peneliti temukan di beberapa daerah yaitu Bali dengan adanya Majelis Desa Pakraman, Minahasa Utara dengan adanya Hukumtua, Papua dengan adanya Para-para Adat, dan Jambi dengan adanya tim sengketa dari tingkat desa sampai kabupaten.

5. Beberapa provinsi sudah mengeluarkan SK Gubernur tentang Pembentukan Tim Konflik dengan melibatkan instansi terkait, DPRD, Kapolda, Ketua Pengadilan Tinggi, Kepala Kejaksaan Tinggi, LSM, akademisi, wartawan dan advokat.

6. Penyelesaian konflik pertanahan melalui mediasi diatur dalam Peraturan Presiden No. 10 tahun 2006 dan Perkaban No. 3 tahun 2011 tentang Pengelolaan Pengkajian Dan Penanganan Kasus Pertanahan, selain itu juga didukung oleh KUHPer, namun dalam pelaksanaannya hasil mediasi sering dilanggar oleh para pihak, atau salah satu pihak melakukan wanprestasi.

\subsection{Rekomendasi}

1. Dalam RUU Pertanahan perlu dimasukkan pasal yang menyatakan bahwa :

a. Setiap konflik pertanahan harus diawali dengan upaya mediasi, dengan tetap mengedepankan mediasi yang berbasis kearifan local.

b. berita acara perdamaian yang merupakan hasil mediasi penyelesaian kasus pertanahan mempunyai kekuatan hukum mengikat bagi para pihak yang terkait dan akan dikenakan sanksi pidana ataupun denda jika tidak dilaksanakan.

2. Tahapan-tahapan proses mediasi perlu disempurnakan, demikian juga jangka waktu setiap tahapan mediasi perlu ditentukan sehingga tidak berlarut-larut, kemudian ditentukan siapa saja yang dapat menjadi mediator. 


\section{DAFTAR PUSTAKA}

\section{Buku dan Laporan Penelitian}

1. Dr. Arkanudin, M.Si, Resolusi Konflik Pertanahan Berdasarkan Pranata Adat Rektor Universitas Kapuas Sintang, Dosen FISIP dan Program Magister Ilmu Sosial UNTAN

2. Gunawan, et al, (2010), Kekerasan Tak Kunjung Usai, Laporan Pemantauan Konflik Agraria, Bina Desa, Jakarta

3. John Echols dan Hasan Shadily, Kamus Inggris Indonesia, cet ke XXV (Jakarta: Gramedia Pustaka Utama, 2003

4. Laporan Penelitian Penataan HGU dalam rangka PPAN, 2007, Pusat penelitian dan Pengembangan Badan Pertanahan Nasional, Jakarta

5. SW Soemardjono, Maria, Tanah Dalam Perspektif Hak Ekonomi Sosial dan Budaya, 2008, Penerbit Buku Kompas, Jakarta,

6. Prof. Dr. Takdir Rahmadi, SH LLM, Mediasi Penyelesaian Sengketa Melalui Pendekatan Mufakat, Penerbit PT RajaGrafindo Perkasa, Jakarta, 2010.

\section{Peraturan Perundang-undangan}

1. UU No. 30 Tahun 1999 tentang Arbitrase dan Alternative Penyelesaian Sengketa

2. Peraturan Presiden No. 10 tahun 2006 tentang Stuktur dan Organisasi BPN

3. Peraturan Mahkamah Agung No. 1 tahun 2008 tentang Tata Cara Mediasi di Pengadilan

4. Peraturan Kepala Badan Pertanahan Nasional No. 3 tahun 2011 tentang Pengelolaan Pengkajian Dan Penanganan Kasus Pertanahan

5. Kitab Undang-Undang Hukum Perdata. 